NBER WORKING PAPER SERIES

\title{
DETERMINANTS OF DISPARITIES IN COVID-19 JOB LOSSES
}

\author{
Laura Montenovo \\ Xuan Jiang \\ Felipe Lozano Rojas \\ Ian M. Schmutte \\ Kosali I. Simon \\ Bruce A. Weinberg \\ Coady Wing \\ Working Paper 27132 \\ http://www.nber.org/papers/w27132

\section{NATIONAL BUREAU OF ECONOMIC RESEARCH \\ 1050 Massachusetts Avenue} \\ Cambridge, MA 02138 \\ May 2020, Revised June 2021
}

We are grateful to our two anonymous reviewers. The views expressed herein are those of the authors and do not necessarily reflect the views of the National Bureau of Economic Research.

At least one co-author has disclosed additional relationships of potential relevance for this research. Further information is available online at http://www.nber.org/papers/w27132.ack

NBER working papers are circulated for discussion and comment purposes. They have not been peer-reviewed or been subject to the review by the NBER Board of Directors that accompanies official NBER publications.

(C) 2020 by Laura Montenovo, Xuan Jiang, Felipe Lozano Rojas, Ian M. Schmutte, Kosali I. Simon, Bruce A. Weinberg, and Coady Wing. All rights reserved. Short sections of text, not to exceed two paragraphs, may be quoted without explicit permission provided that full credit, including (C) notice, is given to the source. 
Determinants of Disparities in Covid-19 Job Losses

Laura Montenovo, Xuan Jiang, Felipe Lozano Rojas, Ian M. Schmutte, Kosali I. Simon, Bruce

A. Weinberg, and Coady Wing

NBER Working Paper No. 27132

May 2020, Revised June 2021

JEL No. J6, J25, J15, J16, Z13

\section{ABSTRACT}

We make several contributions to understanding the socio-demographic divide in early labor market responses to the U.S. COVID-19 epidemic and its policies, benchmarked against two previous recessions. First, monthly Current Population Survey (CPS) data show greater declines in employment in April and May 2020 (relative to February) for Hispanics, younger workers, and those with high school degrees and some college. Between April and May, all the demographic subgroups considered regained some employment. Re-employment in May was broadly proportional to the employment drop that occurred through April, except for Blacks who experienced a smaller rebound. Further, we show that compared to the 2001 recession and the Great Recession, employment losses in the early COVID-19 recession were smaller for groups with very low or very high (vs. medium) education. Second, we show that job loss was larger in occupations that require more interpersonal contact and that cannot be performed remotely. Third, we find pre-COVID-19 sorting of workers into occupations and industries along demographic lines can explain a sizeable portion of the gender, race, and ethnic gaps in new unemployment. For example, while women did suffer more job losses than men, their disproportionate pre-epidemic sorting into remote work compatible occupations shielded women from what would have been even larger employment losses during the epidemic. However, there remain substantial gaps in employment losses across groups that cannot be explained by socioeconomic differences. We find some larger gaps in labor market impacts when we consider the "employed but absent from work" measure present in the CPS, in addition to the more traditional employment and unemployment measures. We conclude with a discussion of policy lessons and future research needs implied by the disparities in early labor market losses from the COVID-19 crisis.

Laura Montenovo

Indiana University

2451 E. 10th Street

Bloomington, IN 47408

lmonten@iu.edu

Xuan Jiang

The Ohio State University

1945 N High St

Columbus, OH 43210

jiang.445@osu.edu
Felipe Lozano Rojas

University of Georgia

355 S Jackson St

Baldwin Hall, 203B

Athens, GA 30602

flozano@uga.edu

Ian M. Schmutte

Terry College of Business

University of Georgia

Athens, GA 30602

schmutte@uga.edu 
Kosali I. Simon

O'Neill School of Public and Environmental Affairs

Indiana University

1315 East Tenth Street

Bloomington, IN 47405-1701

and NBER

simonkos@indiana.edu

Bruce A. Weinberg

Ohio State University

Department of Economics

410 Arps Hall

1945 North High Street

Columbus, $\mathrm{OH} 43210$

and NBER

weinberg.27@osu.edu

Coady Wing

Indiana University

1315 E 10th St

Bloomington, IN 47405

cwing@indiana.edu 


\section{Introduction}

The COVID-19 pandemic made it risky to engage in economic, social, familial, and cultural activities that are otherwise commonplace. These changes have had disparate impacts across demographic and socio-economic groups. Job characteristics have emerged as particularly important moderators. For example, employment losses have been greater among people in jobs that involve face-to-face contact, and fewer losses occurred in jobs that can be done remotely or are in essential industries. On the labor supply side, the transmission mechanism also raises the health risks of work tasks that require face-to-face contact with customers or co-workers, with risk varying with individual characteristics (Guerrieri et al. 2020). Labor supply might decline through other channels as well. For example, people's ability and willingness to work may have declined because the epidemic has compromised child care services, schooling options, and other types of home and family health care availability (Dingel et al. 2020).

This paper focuses on the labor market disruptions and job losses during the early months of the COVID-19 recession in the United States. We document substantial disparities in early epidemic unemployment patterns across demographic sub-populations defined by age, gender, race/ethnicity, parental status, and education. We develop simple measures of job attributes that may be relevant to the epidemic, and show that these measures are associated with employment disruptions. Specifically, people working in jobs with more remote work capacity and less dependence on face-to-face interaction were more secure. Similarly, people working in essential industries were much less likely to become unemployed in the early months of the epidemic. In general, major demographic sub-populations are not evenly distributed across occupations and industries and these differences are an important reason why some demographic groups have fared better than others. We use decomposition techniques to quantify the share of employment disparities that is rooted in preepidemic sorting across occupations and industries. Such sorting explains a substantial share of many of the disparities in employment outcomes. Further, some of the job and industry factors that protected jobs during the early months of the epidemic are often associated with higher income and job security in normal times. This suggests that the epidemic aggravated many existing disparities.

Our research fits with a line of prior literature focused on inequality and the mechanisms that contribute to the persistence of disparities. Research on social stratification takes on "understanding and investigating the sources" of social inequality (Sakamoto and Daniel 2003) through the study of population composition. Our paper examines the distribution of job losses during the early epidemic in a social stratification framework that exploits population subgroups sorting across different jobs. We use information on how subgroups allocate themselves in different occupations and industries to explain the labor market shocks they experience during COVID-19, and the changes 
in inequality dynamics they will experience as a consequence.

We present four broad analyses to investigate disparate impacts in labor markets. First, we use data from the monthly Current Population Survey (CPS) to document and compare disparities in early COVID-19 era unemployment across groups. We find large declines in employment and increases in new unemployment among women, Hispanics, and younger workers. There is also polarization by education, with fewer job losses among college graduates (and above), who can often work remotely, and high school dropouts, who tend to be in essential jobs. Hence, while both groups are somewhat shielded from job loss, highly educated workers are insulated from infection, while less educated workers likely face greater exposure, consistent with Angelucci et al. (2020). We contrast these changes in employment losses during the Great Recession and the 2001 Recession.

Second, we explore disparities in COVID-19 job losses across occupations and industries. We use $\mathrm{O} *$ NET data to develop indices of the extent to which each occupation allows remote work and requires face-to-face interaction. ${ }^{1}$ Employment declined more in occupations requiring greater face-to-face interactions. Workers in jobs that could be performed remotely were less likely to experience new unemployment compared to historical trends. We further classify jobs as essential based on the "Guidance on the essential critical infrastructure workforce" issued by The Department of Homeland Security (2020) using the interpretation in Blau et al. (2020). We show that workers in essential jobs were less likely to lose a job in the early epidemic and were less likely to have been absent from work. All these patterns are stronger in April than in May.

Third, we assess the importance of caring for dependents as a factor in labor supply, estimating changes in employment and work absence for parents and for mothers. Relative to February, women are more likely to be absent from work in March 2020 (at 4 times the rate of March 2019) and be unemployed in April and May. Women with young children experience particularly high rates of absence from work, which is concerning given the widespread closures of schools and childcare. Moreover, single parents, who are disproportionately female, are more likely to have lost jobs. Similarly, Alon et al. (2020) find that social-distancing policies have a larger effect on women than men, unlike in a more "typical" recession; (Albanesi and Kim 2021) also illustrates a sizeable decline in labor force participation and in employment for women, unlike in previous recession. Alon et al. (2020) and Albanesi and Kim (2021) suggest that the impact of the epidemic on working mothers could be persistent.

Our fourth contribution is to measure whether differences in job losses across demographic groups were due to pre-epidemic sorting across occupations and industries. We do so using a

\footnotetext{
${ }^{1}$ Others have used O*NET to define occupations with the ability to work-from-home (Dingel and Neiman 2020; Mongey and Weinberg 2020) and high interpersonal contact (Leibovici et al. 2020).
} 
Oaxaca-Blinder decomposition, which allows us to simultaneously control for pre-pandemic socioeconomic traits associated with labor market opportunities and behavior. We show that a significant share of differences in employment loss across demographic groups is explained by differences in pre-epidemic sorting across occupations. However, for most groups, we also find that a nonnegligible share of the difference in job loss remains unexplained by either occupation sorting or other observable traits, in keeping with Busch (2020). Strikingly, we find that the black-white gap in new unemployment grew between April and May 2020, at a time when one might have naturally expected it to decline. The presence of a large unexplained gap suggests that disparities in job loss in the pandemic are not reducible to differences in job characteristics and could possibly reflect disparate treatment by employers.

\section{Related Research}

The epidemic greatly reduced social and economic activity in 2020, with large sectors of the economy - transportation, hospitality, and tourism - essentially shutting down their normal operations between February and April, as state governments implemented a range of social distancing mandates (Gupta et al. 2020; Goolsbee and Syverson 2020; Bartik et al. 2020; Coibion et al. 2020). In May, both the public and private sectors began to take steps to reopen some economic activities. Mobility measured using cell signals declined in all states, but was larger in those with early and information-focused policies (Gupta et al. 2020). The historically unprecedented increase in initial unemployment claims in March 2020 was largely across-the-board, in all states regardless of local epidemiological conditions or policy responses (Lozano-Rojas et al. 2020). Kahn et al. (2020) show a large drop in job vacancy postings, as an indicator of labor demand, across states, regardless of state policies or infection rates. Adams-Prassl et al. (2020) and Dasgupta and Murali (2020) study disparities in labor market impacts in other countries. There is mounting evidence that layoff statistics may severely underestimate the extent of labor market adjustments. Coibion et al. (2020) estimate that unemployment greatly exceeds unemployment insurance claims in early April.

A large literature illustrates how existing patterns of social stratification shape socio-economic outcomes during crises. Dudel and Myrskylä (2017), Cheng et al. (2019), and Killewald and Zhuo (2019) illustrate disparities in occupational wage gaps and other labor market outcomes on the basis of age, gender, and ethnicity both in the US and abroad. Dudel and Myrskylä (2017) show that the Great Recession shortened the life expectancy of older workers, especially white men. Zissimopoulos and Karoly (2010) examine the short- and longer-term effects of Hurricane Katrina on labor market outcomes by subgroup of evacuees. Beyond labor market outcomes, large economic 
and social events also influence fertility (Grossman and Slusky 2019; Seltzer 2019), marriage (Schneider and Hastings 2015), migration (Sastry and Gregory 2014) and children's well-being (Cools et al. 2017; Schenck-Fontaine and Panico 2019). Given the peculiarities of the COVID-19 economic crisis, it is important to understand which population strata were most affected, why, and how these effects may lead to longer term disparities in well-being.

\section{Data}

\subsection{Current Population Survey}

Our main analysis uses data from the Basic Monthly CPS from February to May 2020. Throughout, the analytic sample used in all regressions consists of all labor force participants ages 18-65 with complete information on gender, children under 6 years old, race/ethnicity, education, state, metropolitan residence, recent unemployment status, occupation and industry codes, and CPS sample weight. To focus on job losses related to the epidemic, we use a measure of recent (new) unemployment, which defines a worker as recently unemployed if he/she is coded as being unemployed in the focal week of the survey month and has been in that status for at most 5 weeks as of March 2020, 10 weeks in April 2020, and 14 weeks in May 2020. ${ }^{2}$

Focusing on recent unemployment allows us to study new job losses using only cross-sectional models. To verify that recent unemployment does indeed track job loss, we checked that the recent unemployment measure behaves like the change in employment rate. That is, we check whether the incidence of recent unemployment across demographic groups in April and in May tracks month-over-month changes from February to April and from February to May, respectively, in the employment-to-population ratio. Evidence reported in Panel A of Appendix Figure A2.1 compares recent unemployment in April 2020 with the February to April change in employment rates by sub-population; Panel B shows the comparison for February and May. It emerges that our recent unemployment measures behaves like the change in the employment rate.

The CPS defines as "absent from job" all workers who were "temporarily absent from their regular jobs because of illness, vacation, bad weather, labor dispute, or various personal reasons, whether or not they were paid for the time off" (U.S. Census Bureau 2019). There was a massive increase in the share of workers coded as employed-but-absent from work between February and April as well as May. During the epidemic, these employed-but-absent workers deserve particular attention as some furloughed employees might have been recorded as short term absent instead of unemployed, among other reasons. Therefore, we performed most of our analysis separately on

\footnotetext{
${ }^{2}$ These surveys use a reference week that includes the 12th of the month (U.S. Census Bureau 2019).
} 
measures of recent unemployment and employed-but-absent.

Further details on our recent unemployment variable, on the definition of the analysis sample, and on the employed-but-absent category during April and May 2020 are in Appendix A.1.

\subsection{O*NET}

We also use data from the 2019 Occupational Information Network (O*NET) Work Context module, which reports summary measures of the tasks used in 968 occupations (O*NET National Center for O*NET Development 2020). These data are gathered through surveys asking workers how often they perform particular tasks, and about the importance of different activities in their jobs. Some of the questions relate to the need for face-to-face interaction with clients, customers, and co-workers. Other questions assess how easily work could be done remotely. For details on how this information is collected in $\mathrm{O}^{*} \mathrm{NET}$, refer to Appendix A.3. We use such questions to build two occupation indices: Face-to-Face (questions on face-to-face discussions and physical proximity) and Remote Work (questions on use of electronic mail, written letters, and phone conversation). ${ }^{3}$ It is important to note that these occupational characteristics in the $\mathrm{O} * \mathrm{NET}$ are measured prior to the epidemic. This means that they do not capture "work practice innovations" that may have been induced by the epidemic, such as the fact that many teachers and professors have transitioned from face-to-face to online instruction during the epidemic. To check how well our two indices perform, we rank the occupations by their corresponding indices, and create a list of the top and bottom 5\% Face-to-Face and Remote Work occupations. We realize that, unsurprisingly, most of the top 5\% Face-to-Face occupations are in the medical sector, which may be affected differently during the epidemic. Hence, we also show a list of the top non-medical occupations. The rankings (reported in Appendix Tables A4.2 and A4.3 for Face-to-Face and Remote Work, respectively) are reassuring, indicating that these indices measure what we expected.

We also compared our Remote Work and Face-to-Face indices with Dingel and Neiman (2020)'s Telework classification, which might be viewed as an alternative to our Remote Work index. The correlation between our Face-to-Face index and Remote Work index is only 0.03, suggesting that our two indices capture different features of an occupation. The correlation between the Face-toFace index and Dingel and Neiman (2020)'s Teleworkable variable is -0.36 . The occupations that score high in our Face-to-Face index, tend to rank low in Teleworkability. Finally, the correlation between our Remote Work index, and the Teleworkable variable is 0.51 , suggesting that the two measures are indeed broadly similar.

\footnotetext{
${ }^{3}$ The complete list of the specific questions used to build each of the two indexes is on Appendix Table A4.1.
} 


\subsection{Homeland Security Data on Essential Work}

The U.S. Department of Homeland Security (DHS) issued guidance that describes 14 essential critical infrastructure sectors during the COVID-19 epidemic. ${ }^{4}$ We follow Blau et al. (2020)'s definition of essential industries, which matches the text descriptions to the NAICS 2017 fourdigit industry classification from the U.S. Census Bureau, ${ }^{5}$ and to the CPS industry classification system. From the 287 industry categories at the four-digit level, 194 are identified as essential in 17 out of 20 NAICS sectors. Appendix Table A4.4 gives an abbreviated list of essential industries to clarify the classification scheme.

\section{Employment Disruptions in Three Recessions}

Figures 1 and 2 show the change in employment for the COVID-19 Recession compared with the peak-to-trough change in employment for the 2001 Recession (March 2001 to November 2001) and the Great Recession (December 2007 to June 2009). We seasonally-adjusted the change in employment for the 2001 Recession and the Great Recession using calendar month fixed effects from January 2015-December 2019. For COVID-19, we focused on two time periods that cover the initial "closing" phase of the pandemic (i.e. from February to April) and also a longer period (i.e. from February to May) that adds the ensuing "reopening" phase. All estimates use CPS sampling weights.

The light blue and green lines on the figures show that employment losses during the first months of the COVID-19 epidemic dwarf the declines for the other two recessions, which span nine and nineteen months respectively. This is true even after the COVID-19 reopening phase, during which employment rebounded substantially. The size and speed of the COVID-19 recession are reinforced in Appendix Figure A5.1, which shows seasonally-adjusted non-farm employment from March 2000 and May 2020. The bars in Figure 1 show the change in the employment rate for sub-populations defined by gender, race, ethnicity, age, and education. Figure 2 shows employment changes by marital and parental status. Almost no group is spared from employment loss during any of the three recessions. However, the pattern of employment disruption is noticeably different in the early months of the COVID-19 recession.

Young (ages 18-24) and Hispanic workers fared the worst during the COVID-19 pandemic when compared to older and non-Hispanic workers and to the previous recessions. Blacks also fared worse, but by a smaller margin. Our conjecture is that these groups disproportionately work

\footnotetext{
${ }^{4}$ The list of critical infrastructure jobs is available at: https://www.cisa.gov/

${ }^{5}$ North American Industry Classification System. Available at https://www.census.gov/
} 
in industries that are particularly hit by social distancing measures, such as food service, cosmetic or non-essential retail industries. Further, employment declines more for women than for men, and for single adults versus married ones.

Employment effects are polarized by education: employment declines less for high school dropouts and college graduates compared to the intermediate education groups. As we show below, highly-educated workers have better options to work remotely, limiting in-person interactions. By contrast, less educated workers are more likely to be in essential positions. While polarization is consistent with recent trends in the labor market, this kind of pattern was not a feature of the two previous recessions (Autor et al. 2006). ${ }^{6}$

Comparing the decrease in employment between February and April (light blue) to that between February and May (light green) indicates that there were gains in employment between April and May as states began re-opening. The recovery in employment that the groups experienced between April and May were broadly proportional to the employment losses that occurred between February and April. Thus, the distributional incidence of job loss and recovery are largely symmetric, with the notable exception of Black workers, who did not recover in May as much as would have been expected given their decline in employment in April.

Figure 2 reports similar results by family structure. Figure 2 shows that married, spousepresent individuals experience a smaller decrease in employment than "single" (i.e. those who are unmarried or have an absent spouse) individuals, regardless of whether we compare April or May to February. Moreover, parents with own children under 18 living in the household fared worse than those without. Single parents, who are disproportionately female (72\%), experienced the largest decrease in employment, while the age of children is weakly related to the change in employment during these months.

Taken together, this analysis highlights that Hispanics, young workers (between 18 and 24 years old), and single parents were the most vulnerable workers early in the epidemic, and those most in need of policy attention.

\footnotetext{
${ }^{6}$ We formally check for polarization in two ways. First, for each of the three recessions, we create a graph showing the employment change for each of the four education categories: less than high school, high school graduate, some college, and college graduate (on the $\mathrm{X}$-axis, in increasing order). We observe a very marked U-shape across the education groups during the COVID recession, but not for the other two recessions. Second, using a regression on data from the COVID-19 recession, we reject the hypothesis that workers with less than a high school degree and those with a graduate degree jointly experience a drop in employment equal to that of the intermediate education group (i.e. high school graduate and some college). In other words, our p-value (equal to 0) for the F-test rejects the hypothesis of non polarization. College graduates and those with less than a high school diploma experience a drop in employment that is statistically lower than the one suffered by the intermediate education group.
} 


\section{Job Tasks and Recent Unemployment}

\subsection{Job Tasks and the Labor Market: Descriptive Analysis}

Figure 3 shows the mean of the Remote Work and Face-to-Face indices across sub-populations in the February 2020 CPS, providing insight into pre-epidemic worker sorting across occupations. Women tend to work in jobs that both allow more remote work and involve more face-to-face activities than men. Hispanics disproportionately work in jobs that largely cannot be conducted remotely. Younger workers (age 18-24) are in jobs with fewer remote work prospects and more face-to-face interaction, although the differentials are not as large. Remote work scores increase substantially with education.

To examine employment disruptions in the early epidemic, we use data from the March, April, and May waves of the 2020 CPS. The March CPS data were collected largely before the major responses are observed and we view March as a hybrid period. As indicated, we classified people as recently unemployed if they were currently unemployed and had became unemployed within the past 5 weeks (March CPS), 10 weeks (April CPS), and 14 weeks (May CPS). Ignoring reemployment, this measure captures employment disruptions since February in each subsequent monthly CPS. Figures 4 and 5 compare recent unemployment rates with Remote Work scores and face-to-face scores at the occupation level in the April and May CPS. In both graphs, the left panel shows that recent unemployment rates tended to be lower in occupations with higher scores on the remote work index, suggesting that remote work capacity helped protect employment. In contrast, the right panel shows that recent unemployment rates were typically higher in occupations that involve more face-to-face tasks.

\subsection{Job Tasks and the Labor Market: Regression Analysis}

To assess the connection between worker and job characteristics and recent job losses, we fit regressions with the following form:

$$
\begin{aligned}
y_{i j k s} & =\text { Face }_{j} \beta_{1}+\text { Remote }_{j} \beta_{2}+\text { Essential }_{k} \beta_{3} \\
& + \text { Female }_{i} \beta_{4}+\text { Child }_{i} \beta_{5}+\left(\text { Child }_{i} \times \text { Female }_{i}\right) \beta_{6} \\
& +X_{i} \delta+\xi_{s}+\epsilon_{i j k s}
\end{aligned}
$$

Here $y_{i j k s}$ is an indicator that person $i$ with occupation $j$, industry $k$, in state $s$, is recently unemployed (Table 1) or temporarily absent from work (Table 2). Face $_{j}$ and Remote $_{j}$ are the indices 


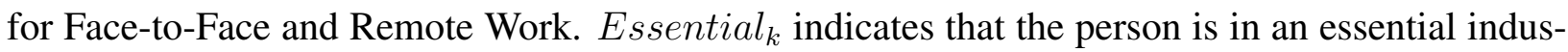

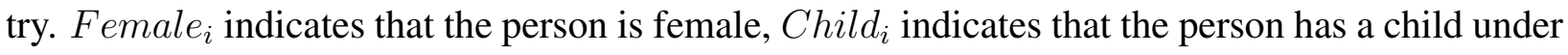
age 6 , and $X_{i}$ is a vector of covariates, including a quadratic in age, race/ethnicity indicators, and education indicators. All models include state fixed effects, denoted by $\xi_{s}$, and, in some specifications, they include state specific epidemiological conditions as measured by the log of COVID cases, which are interacted with occupation characteristics. Occupation fixed effects are included in some but not all specifications because they subsume the occupation characteristics (i.e. Face ${ }_{j}$, Remote $_{j}$, and Essential $_{j}$ ).

Table 1 reports estimates from March (left panel), April (middle), and May (right). Column (1) in all three panels shows estimates from models that control for occupation and individual characteristics, but not for the number of COVID-19 cases in the state. Column (2) includes the log of state COVID cases (The New York Times 2020). Column (3) replaces the job task indices with occupation and industry fixed effects to account for any additional time-invariant job characteristics. Table 2 reports parallel estimates for temporary absence from work.

The coefficients on the Remote Work and the Face-to-Face indices reinforce the pattern in Figures 4 and 5. In the analysis of the April CPS, the model in Column (1) implies that recent unemployment rates were 1.6 percentage points higher for people working in jobs that score 1 standard deviation (SD) higher on the Face-to-Face index. The recent unemployment rate in our April sample was 12.6 percent, which means that a $1 \mathrm{SD}$ increase in the Face-to-Face score is associated with a $13 \%$ higher risk of being recently unemployed. The relationship is almost identical in the analysis based on the May CPS. In contrast, there is no association between the Face-to-Face index and recent unemployment in the March CPS, implying that the connection between employment instability and the Face-to-Face index was not a pre-existing feature of the labor market. The coefficient on the Remote Work index is negative and significant in March, suggesting that there was a small pre-epidemic connection between remote work and employment disruption. However, the magnitude of the coefficient on Remote Work is 7 times larger in April and almost 6 times larger in May than in March. Working in a job that scores 1 SD higher on Remote Work is associated with a 4.6 percentage point lower risk of recent job loss, which is $44 \%$ of the recent unemployment rate in April. Likewise, the coefficient on "Essential" (8.9 percentage points) indicates that working in an essential industry is associated with a $71 \%$ lower probability of recent unemployment and the magnitude in April is almost 13 times higher than in March. Column (2) includes interactions between state level COVID-19 cases and job characteristics (Model 2). The essential industry and Face-to-Face variables do not have strong interactions with COVID-19 cases, but Remote Work has a strong negative interaction with COVID-19 cases, indicating that remote work potential is particularly important in high case environments. 
The regressions show that recent unemployment rates vary with individual characteristics. Recent unemployment rates are about 3 percentage points higher for women in April and May, however when occupation and industry fixed effects are included the difference falls to one percentage point. The coefficient on the interaction term between female and children under age 6 is small and not statistically significant, suggesting that child care responsibilities did not explain much of the gender gap in unemployment early in the epidemic; however, we later show that presence of young children is a factor in absence from work. Recent unemployment rates are substantially higher for younger workers and decline with age at a decreasing rate. Recent unemployment is lower among college educated workers: graduate degree holders are about 7.9 percentage points less likely to have become unemployed in the 10 weeks leading up to the April CPS, and college graduates are about 4.4 percentage points less likely to be recently unemployed. This relationship is much weaker in March, but on the same level during May. Including occupation and industry fixed effects attenuates the education gradient somewhat, but it remains strong and significant. Recent unemployment rates are about 3 percentage points lower among workers living in metropolitan areas for both April and May. Again, including occupation and industry fixed effects lessens but does not eliminate this relationship. Overall, occupation and industry characteristics were far more important in April and May than in March. We attribute this increase, and the slight decrease from April to May, to the spread of the pandemic, the policy responses, and their subsequent easing during the first part of May.

Table 2 shows results from models with "employed but absent" as the outcome. Our estimates show that workers jobs relying heavily on face-to-face interactions are more likely to experience absence from work, while those who can work remotely more easily, and those in essential industries are less likely to be absent from work. The coefficients on job attributes have similar signs in March and April, but the magnitude of the coefficients is much larger in April. The magnitude declines somewhat in May, which may indicate that absences precede dismissals. However, the data classification issues we discussed in the data description make this a tentative conclusion.

The education gradient is very similar to the one found for recent unemployment, with education protecting against work absence. Women with young children are particularly likely to be temporarily absent in all months, suggesting that child care responsibilities likely played an early and lasting role in absence rates. To probe the timing of effects, we plotted the coefficients from Columns (3) of Tables 1 and 2, respectively, over time during the pandemic (March through May 2020) and for the same months in 2019. In several cases, we can spot a striking change in coefficient of the variables in both graphs starting in March 2020, the onset of the epidemic. Instead, coefficients referring to 2019 are more centered around 0. Graphs are shown in Appendix figures A7.1 and A7.2. 


\subsection{Further Analyses and Robustness Checks}

We conducted a series of sensitivity analysis to assess the robustness of our results. We report these results in the Appendix and discuss them briefly here.

First, we explored whether mortality risk $^{7}$ from COVID-19 affected labor supply among highrisk groups by estimating regressions that include a measure of COVID-19 mortality risk as a covariate. The results are presented in Table A8.1 for recent unemployment and in Table A8.2 for absent from work. Overall, they suggest that among people working in non-essential jobs with average Face-to-Face and Remote Work capacity, workers with higher COVID-19 mortality risk were actually less likely to experience a recent unemployment spell in April and May. In April, the coefficient on the mortality index implies that a 1 SD increase in mortality risk reduced the recent unemployment rate by about 1.3 percentage points. Since our mortality risk measure is mainly driven by age and gender, this likely reflects that older workers had more job security than younger workers. However, the coefficient on the interaction term between mortality risk and the Remote Work index is positive, implying that this pattern was partly offset for people working in jobs that were more suitable for remote work. In contrast, Mortality Risk does not appear to be a factor in temporary absences during April nor May.

In our main analysis, we consider recent unemployment and recent absence as separate outcomes. In supplementary work, we combined the two outcome variables into a single dependent variable indicating either recent unemployment or recent absence. The regression results are qualitatively unchanged, but the magnitudes are, as expected, frequently larger because both outcomes behave similarly. These estimates are reported in Appendix A.9, Table A9.1.

Next, we examined the possibility that the relationship between job characteristics and recent unemployment reflects pre-existing patterns of employment instability not related to the epidemic. A consistent and comparably strong relationship between job characteristics and employment even before the COVID-19 epidemic, would throw into question our finding that such characteristics determined labor outcomes during April and May 2020. As a check, we run the same models above on April and May 2019 data. We find no clear relationship between either job Face-toFace Index or being in an essential industry and recent unemployment. There appears to be a negative correlation between Remote Work and recent unemployment in April and May 2019, but

\footnotetext{
${ }^{7}$ We use Bayes' theorem to infer mortality rates by age and gender from Chinese Center for Disease Control and Prevention (2020). Specifically, we calculated:

$$
\operatorname{Pr}(\text { Death } \mid \text { Gender, Age })=\frac{\operatorname{Pr}(\text { Age } \mid \text { Death }) \cdot \operatorname{Pr}(\text { Gender } \mid \text { Death }) \cdot \operatorname{Pr}(\text { Death })}{\operatorname{Pr}(\text { Gender }) \cdot \operatorname{Pr}(\text { Age })}
$$

Where: Gender $=\{$ Female, Male $\}$ and Age $=\{20-29, \ldots, 70-79,80+\}$. We normalize the variable to have mean of zero and standard deviation of one on the entire CPS sample.
} 
the strength of this relationship is an order of magnitude larger in 2020 than in 2019. For temporary absence, we find a positive and significant coefficient on Face-to-Face, but of a much smaller magnitude in 2019 (between half up to seven times as small in 2019 compared to 2020, depending on the specification). Tables A10.1 and A10.2 in Appendix A.10 show the full results. These results suggest that while there may have been some preexisting relationships between the various job characteristics we study and labor market outcomes, these characteristics became considerably more important during the epidemic.

We further probed the robustness of our results to the number of weeks used to define the recently unemployed variable. In the robustness check, we varied the number of such weeks. The model coefficients are not sensitive to the cutoff used to define "recent" unemployment. Appendix A.11 includes the graphs we used for this exercise (figures A11.1 and A11.2).

Finally, we replicated Figure 3 and our regression specifications using the definition of teleworkability as defined by Dingel and Neiman (2020). We find the same socio-demographic groups scoring high (or low) in both teleworkability and remote work, showing the similarity of these two measures. On the regression models with the Teleworkable variable in place of our Remote Work index, we find that the estimates are very similar to our results, and our main analysis are robust to this alternative measure. The graph is reported in Appendix Figure A6.1 and the regressions are presented in Tables A12.1 and A12.2 in Appendix A.12.

\section{Decomposing Group Differences in Recent Unemployment}

The analysis so far shows that recent unemployment rates in April and May varied substantially across sub-populations. Differences in the kinds of jobs workers held at the onset of the epidemic likely contribute to this variation. In this section, we use a version of the Oaxaca-Blinder decomposition to quantify the role of pre-epidemic sorting more formally (Oaxaca 1973; Blinder 1973). We find robust evidence that pre-epidemic group differences in job characteristics explain the majority of the recent unemployment gap for most comparisons. However, we also show that significant disparities in unemployment are not explained by observable characteristics. Rather, they reflect differences in the rates at which different groups became unemployed at the start of the pandemic, holding job sorting and other characteristics fixed.

\subsection{Decomposition Model}

We examine six aggregate gaps in recent unemployment rates: White vs. Black, High School Graduate vs. High School Drop Out, Female vs. Male, Non-Hispanic vs. Hispanic, College graduate vs. 
High school graduate, and Older vs. Younger workers. For each pair, we specify regression models linking recent unemployment with observed characteristics in each of the groups:

$$
\begin{aligned}
& y_{i}^{A}=\alpha_{0}^{A}+X_{i}^{A} \beta^{A}+\epsilon_{i}^{A} \\
& y_{i}^{B}=\alpha_{0}^{B}+X_{i}^{B} \beta^{B}+\epsilon_{i}^{B}
\end{aligned}
$$

In these models, $y_{i}^{g}$ is a binary measure of recent unemployment for person $i$ who is a member of sub-population $g \in[A, B]^{8} ; X_{i}^{g}$ is a vector of covariates; $\alpha_{0}^{g}$ is a group specific intercept; and $\beta^{g}$ is a group specific vector of coefficients. Let $\bar{y}^{g}$ and $\bar{X}^{g}$ represent the average value of the recent unemployment measure and the covariates among group $g$. The average difference in the shares of workers reporting recent unemployment between $A$ and $B$ is:

$$
\bar{y}^{A}-\bar{y}^{B}=\bar{X}^{A} \beta^{A}-\bar{X}^{B} \beta^{B}+\left(\alpha_{0}^{A}-\alpha_{0}^{B}\right)
$$

In the standard Oaxaca-Blinder decomposition, the difference in the share recently unemployed between the two groups can be expressed as:

$$
\bar{y}^{A}-\bar{y}^{B}=\left(\bar{X}^{A}-\bar{X}^{B}\right) \beta^{A}+\left[\bar{X}^{B}\left(\beta^{A}-\beta^{B}\right)+\left(\alpha_{0}^{A}-\alpha_{0}^{B}\right)\right]
$$

In this form of the decomposition, the first term, $\left(\bar{X}^{A}-\bar{X}^{A}\right) \beta^{A}$, is called the "endowment effect" and represents the part of the aggregate gap that is explained by differences in average value of observed covariates between the two groups. The second term, $\left[\bar{X}^{B}\left(\beta^{A}-\beta^{B}\right)+\left(\alpha_{0}^{A}-\alpha_{0}^{B}\right)\right]$, is called the "coefficient" effect. It reflects the gap that arises because workers in the two groups have different unemployment outcomes even given the same observed endowments. Oaxaca and Ransom (1994) point out that the relative size of the endowment and coefficient effects depends on which group's coefficients are treated as "correct" or "non-discriminatory". The equation above treats group $A$ coefficients as the benchmark, but the decomposition could just as easily be written with group $B$ as the benchmark, leading to a different result. To circumvent this ambiguity, we follow the recommendation in Fortin (2006) to use coefficients from a pooled regression as the benchmark. In the pooled regression, groups $A$ and $B$ are allowed to have different intercepts but are restricted to have the same coefficients on the observed covariates. ${ }^{9}$ Using $\beta^{P}$ and $\alpha_{0}^{P}$ to

\footnotetext{
${ }^{8}$ In each decomposition, group B is the relatively disadvantaged group in terms of employment.

${ }^{9}$ Our notation $\beta^{P}$ (and $\alpha^{P}$ ) correspond to $\beta^{*}$ in Jann (2008), the nondiscriminatory coefficients vectors. We implement the two-fold Oaxaca decomposition using the pooled option in STATA.
} 
represent coefficients from the pooled model, the aggregate gap in recent unemployment rates is:

$$
\bar{y}^{A}-\bar{y}^{B}=\underbrace{\left[\left(\bar{X}^{A}-\bar{X}^{B}\right) \beta^{P}\right]}_{\text {Endowment Effect }}+\underbrace{\left[\left(\bar{X}^{A}\left(\beta^{A}-\beta^{P}\right)+\left(\alpha_{0}^{A}-\alpha_{0}^{P}\right)\right)-\left(\bar{X}^{B}\left(\beta^{B}-\beta^{P}\right)+\left(\alpha_{0}^{B}-\alpha_{0}^{P}\right)\right)\right]}_{\text {Coeff. Effect }}
$$

The first term in square brackets represents the part of the aggregate recent unemployment gap that can be attributed to differences in pre-epidemic endowments, using the coefficients from the pooled model as the benchmark. The coefficient effect is characterized by the deviation between the pooled coefficients and each group's unrestricted coefficients. Using this framework, we say that $\left.E=\left(\bar{X}^{A}-\bar{X}^{B}\right) \beta^{P}\right) /\left(\bar{y}^{A}-\bar{y}^{B}\right)$ is the share of the aggregate gap coming from the endowment effect. ${ }^{10}$ The overall explained share can itself be decomposed to determine the share of the gap explained by specific groups of variables.

Specifically, we can write

$$
\left(\bar{X}^{A}-\bar{X}^{B}\right) \beta^{P}=\left(\bar{X}^{A, D e m}-\bar{X}^{B, D e m}\right) \beta^{P, D e m}+\left(\bar{X}^{A, J o b}-\bar{X}^{B, J o b}\right) \beta^{P, J o b}
$$

Where $\bar{X}^{g, D e m}$ and $\bar{X}^{g, J o b}$ are group $g$-specific averages of demographic and job-specific characteristics and $\beta^{P, D e m}$ and $\beta^{P, J o b}$ are conformable parameter vectors. It follows that the overall explained share can be decomposed into a share associated with demographic and job factors so that $E=E^{D e m}+E^{J o b}$. In practice, we break the explained share into several categories, including demographic, industry, and occupation-specific characteristics. ${ }^{11}$

\subsection{Decomposition Results}

Figure 6 summarizes the most significant gaps in our data. For ease of visualization, they appear ordered from smallest to largest for: White vs. Black, High School Graduate vs. High School Drop Out, Female vs. Male, Non-Hispanic vs. Hispanic, College graduate vs. High school graduate, and Older vs. Younger workers. Figure 7 shows the same decompositions, but applied to the May data for recent unemployment. The full results of the decompositions appear in Appendix Tables A13.1 and A13.3 for April and May 2020, respectively.

\footnotetext{
${ }^{10}$ This decomposition requires a normalization that specifies how much of the unexplained gap comes from positive deviations from the pooled outcome for the advantaged group, and how much from negative deviations for the disadvantaged group. Our estimates assume the deviations are symmetric; that is, $\left(\bar{X}^{A}\left(\beta^{A}-\beta^{P}\right)+\left(\alpha_{0}^{A}-\alpha_{0}^{P}\right)\right)+$ $\left(\bar{X}^{B}\left(\beta^{B}-\beta^{P}\right)+\left(\alpha_{0}^{B}-\alpha_{0}^{P}\right)\right)=0$.

${ }^{11} \mathrm{~A}$ similar exercise can be conducted to break the coefficient effect across categories. However, the differences in coefficient effects are generally not statistically significant when we focus on the same groups of demographic and job characteristics. As a result, we cannot say with confidence whether certain types of jobs are differentially protective against job loss.
} 
For each gap, we estimate three versions of the pooled decomposition model. Each model includes basic demographic characteristics (age, gender, race, ethnicity, education, and presence of young children) and state controls. The three models are differentiated by how much detail we include regarding job characteristics. Model A includes the Face-to-Face, Remote Work, and Essential Job indices. Model B adds a full set of 523 occupation dummies which, of course, absorb the variation from the Face-to-Face and Remote Work indices. ${ }^{12}$ Finally, Model $\mathrm{C}$ adds a full set of 261 industry dummies, which absorb the variation from the Essential index. Hence, Model C is the most general specification and nests Model B, which nests Model A.

Focusing first on Model A for the April data, the explanatory contributions of task-based sorting and essential industry sorting operate in different directions across groups. For example, the non-Hispanic/Hispanic gap is quite large at -4.45 percentage points, relative to a baseline recent unemployment rate of 12.1 percent. About 52.18 percent of the raw gap arises because Hispanic workers are over-represented in jobs with little opportunity for remote work. However, these relative losses are partially offset by the fact the Hispanic workers are over-represented in essential jobs, accounting for -12.24 percent of the raw gap. This pattern is similar for the Black/White gap.

The gender gap displays a different pattern; continuing with the April data, most of the gender gap is unexplained, and in fact sorting on the basis of remote work predicts a smaller gap than actually appears in the data because women are more likely to be in jobs that permit remote work. Moving to Models B and C, we see that sorting by occupation and industry explains a sizeable portion of the gender, race, and ethnic-origin gaps in recent unemployment. However, there remain substantial unexplained differences in employment losses across groups even in these more detailed decompositions.

The largest gaps we observe are between college graduates and high-school graduates, and between older versus younger workers. In Model C, we observe that a majority of both raw gaps can be attributed to differences in the types of jobs workers held when the epidemic started. The less detailed Model A suggests that a large portion of the gap was associated with differences in capacity for remote work, and partially offset by employment in essential industries.

All of the patterns we observe are consistent from April to May except one: the gap in recent unemployment between Black and White workers. In May, the raw gap is -0.0345 percentage points; double the -0.0171 gap from April. Curiously, all of the growth in the gap is from sources that are not explained by the individual or job characteristics included in the model. Overall, re-

\footnotetext{
${ }^{12}$ For Model B, Table A13.2 in Appendix A.13 reports the share of variation in April explained by sorting across five top-level categories in the Census occupational classification system: "Management, Business, Science, and Arts", "Service", "Sales and Office", "Natural Resources, Construction, and Maintenance", "Production, Transportation, and Material Moving". A sixth category, "Military Specific Operations", does not appear because the CPS is a survey of the civilian non-institutional population. Table A13.4 shows the same results using May data.
} 
cent unemployment rates fell in May relative to April, as they did for headline unemployment. Consistent with this trend, recent unemployment also fell for White workers. However, recent unemployment rates increased slightly for Black workers. Our decomposition indicates that whatever prevented recent unemployment rates from falling for Black workers was unrelated to any of the individual or job characteristics included in our model. One explanation relates to how the CPS classifies workers as unemployed versus employed-but-absent across months. On the other hand, this result may indicate that even given the same characteristics, white workers are more likely to be re-employed than Black workers in a recovery.

Across the board, differential sorting into occupations and industries is highly relevant in explaining gaps in recent unemployment. This finding echoes recent work by Athreya et al. (2020), who find that the service sectors are most vulnerable to social-distancing. Nevertheless, the precise sources of employment losses vary across groups in ways that are only partially explained by differential exposure to particular types of tasks or sectors. Finally, we note that demographic controls do not explain a large part of any of the gaps, suggesting a limited role for labor supply effects in determining recent job losses.

We ran the above models on data from the same months in 2019 as well (Tables A13.1 and A13.3 in the Appendix), to investigate the role that occupation sorting played in explaining differences in job loss prior to the pandemic. We find that the magnitude of most raw gaps for the groups we consider is much smaller in 2019 than in 2020. Even before the pandemic, the remote work index does for some groups explain a statistically significant, but economically small share of differences in job loss. Nevertheless, the size and the significance of our 2020 results, compared to 2019, establish that occupational sorting in high remote work and low face-to-face jobs did contribute substantially more to disparities in job loss during the epidemic than in normal times. There are two examples that are particularly meaningful. The first one is the white/black raw gap, which in 2019 was significant, but about half the size of the 2020 raw gap. Furthermore, while remote work explained only $3.64 \%$ of the 2019 , that increases to $23.31 \%$ in 2020 . Another example is the HS/non-HS gap. While in 2019 remote work explained more than $57 \%$ of the raw gap, the estimated gap is statistically insignificant and approximately zero. However, in 2020, that percentage increases to almost $72 \%$ and the raw gap is more than 6 times as large as the previous year, and this time statistically significant.

\section{Conclusion}

After only a few months, the COVID-19 job losses were larger than the total multi-year effect of the Great Recession. Moreover, there are large disparities in job losses across demographic groups and 
people with different levels of education. Much of the overall variation in recent unemployment stems from differences across different types of jobs. For example, in the April CPS, we found that recent unemployment rates are about $44 \%$ lower among workers in jobs that are more compatible with remote work. In contrast, workers in jobs that require more face-to-face contact are at higher risk of recent unemployment.

Formal decomposition analysis shows that a substantial share of the disparity in recent unemployment across racial, ethnic, age, and education sub-populations can be explained by differences in pre-epidemic sorting across occupations and industries that were more vs less sensitive to the COVID-19 shock. However, in almost all cases, a large share of the gaps in job losses between social strata cannot be explained by either occupation sorting or other observable traits. There are at least three possible sources for the unexplained share. First, workers may have different labor supply responses to the epidemic. Second, variation in exposure to labor demand shocks may not be fully reflected in the occupational or demographics differences we consider. Third, workers may face disparate treatment when employers make layoff and recall decisions. The available data do not allow us to distinguish between these three channels.

These results raise concerns about the the risks of workplace COVID-19 exposure and how that risk is distributed across the population. More highly educated workers had more job security during the epidemic because their work is often compatible with remote work. The least educated workers have also experienced less recent unemployment, largely due to their concentration in essential industries. But these workers likely face greater exposure to COVID-19 itself. Thus, the higher job security available to workers with high and low education potentially masks a disparity in the health risks. New government policies or private sector innovations that increase the viability of remote work for a larger share of the economy could be extremely valuable.

The analysis of May CPS data show an uptick in employment that likely derives from the business reopenings implemented in most states during that month. Although rates of recent unemployment and absence from work are still high in the May CPS data, the data do suggest that reopening policies reduced the negative impact of the epidemic on the labor market. The improvements in labor market outcomes are consistent with cell signal data, which show a rise in physical mobility starting in mid-April and continuing through May (Nguyen et al. 2020). Of course, it is unclear whether these returns to normalcy can be sustained in the face of more recent increases in COVID-19 cases and hospitalizations.

In the meantime, our results highlight that there are large disparities in the current labor market crisis, and they suggest a role for targeted public policies. Although women with young children do not have statistically larger increases in recent unemployment compared to men with young children, despite the disruptions in school and child care, their higher rate of "employed-but-absent" 
is worrying and could indicate larger losses in future employment. Moreover, single parents, who are overwhelmingly women, experienced a larger decrease in employment between February and April as well as between February and May than their married counterparts. Efforts to support new child care options are important in this setting. In May, during the re-opening phase, we found some evidence of racial disparities in re-employment. For example, Black workers become employed at a proportionately lower rate compared to other groups. Further, the decomposition analysis shows that while for most groups recent unemployment decreases in May, it increases slightly for Blacks, and this gap is not related to any of the individual or job characteristics we considered.

Our results point at deeper structural damage to the economy. Previous research documents large scarring effects of graduating from high school and college during a recession, and the longer term effects of early career setbacks may be even larger than the near term effects (Rothstein 2019). Our work shows that recent unemployment rates are very high among the youngest workers overall and in comparison to earlier recessions. Since finding and forming productive employment matches is costly, efforts to support early career workers as well as older displaced workers may need to be a particular target of policy in the near future. Furthermore, workers receive health care and other benefits through employers. Assuming economic conditions return to their preepidemic state, policymakers are right to help workers maintain jobs and preserve links to their employers. On the other hand, if economic conditions do not return to normal rapidly, then the smooth reallocation of workers into different types of jobs may also be important. 


\section{References}

Adams-Prassl, A., Boneva, T., Golin, M., and Rauh, C. (2020). Inequality in the impact of the Coronavirus shock: New survey evidence for the UK. Cambridge-INET Working Paper Series.

Albanesi, S. and Kim, J. (2021). The gendered impact of the covid-19 recession on the us labor market. Technical report, National Bureau of Economic Research.

Alon, T. M., Doepke, M., Olmstead-Rumsey, J., and Tertilt, M. (2020). The impact of COVID-19 on gender equality. National Bureau of Economic Research.

Angelucci, M., Angrisani, M., Daniel, B. M., Kapteyn, A., and Schaner, G. S. (2020). Remote work and the heterogeneous impact of COVID-19 on employment and health. National Bureau of Economic Research.

Athreya, K., Mather, R., Mustre-del Río, J., and Sánchez, J. M. (2020). COVID-19 and households' financial distress part 1: Employment vulnerability and (financial) pre-existing conditions. Federal Reserve Bank of Richmond.

Autor, D. H., Katz, L. F., and Kearney, M. S. (2006). The polarization of the US labor market. The American Economic Review, 96(2):189-194.

Bartik, W. A., Bertrand, M., Zo, C. B., Glaeser, L. E., Luca, M., and Stanton, T. C. (2020). How are small businesses adjusting to COVID-19? Early evidence from a survey. National Bureau of Economic Research.

Blackburn, J., Yiannoutsos, C. T., Carroll, A. E., Halverson, P. K., and Menachemi, N. (2020). Infection fatality ratios for COVID-19 among noninstitutionalized persons 12 and older: Results of a random-sample prevalence study. Annals of Internal Medicine.

Blau, F. D., Koebe, J., and Meyerhofer, P. A. (2020). Essential and frontline workers in the COVID19 crisis. Econofact.

Blinder, A. S. (1973). Wage discrimination: Reduced form and structural estimates. Journal of Human Resources, pages 436-455.

Bogage, J. (2020). Coronavirus unemployment guide: What to do if you get laid off or furloughed. The Washington Post.

Borden, T. (2020). The Coronavirus outbreak has triggered unprecedented mass layoffs and furloughs. Business Insider. 
Busch, F. (2020). Gender segregation, occupational sorting, and growth of wage disparities between women. Demography, 57(3):1-26.

Cheng, S., Tamborini, C. R., Kim, C., and Sakamoto, A. (2019). Educational variations in cohort trends in the black-white earnings gap among men: Evidence from administrative earnings data. Demography, 56(6):2253-2277.

Chinese Center for Disease Control and Prevention (2020). The epidemiological characteristics of an outbreak of 2019 novel Coronavirus diseases (COVID-19) - China, 2020. China CDC Weekly, 2(8):113-122.

Coibion, O., Gorodnichenko, Y., and Weber, M. (2020). Labor markets during the COVID-19 Crisis: A preliminary view. National Bureau of Economic Research.

Cools, S., Markussen, S., and Strøm, M. (2017). Children and careers: How family size affects parents' labor market outcomes in the long run. Demography, 54(5):1773-1793.

Dasgupta, K. and Murali, S. (2020). Pandemic containment and inequality in a developing economy. IIM Bangalore Research Paper n. 613.

Dingel, J. I. and Neiman, B. (2020). How many jobs can be done at home? Journal of Public Economics, 189:104-235.

Dingel, J. I., Patterson, C., and Vavra, J. (2020). Childcare obligations will constrain many workers when reopening the US economy. SSRN Working Paper, (ID 3579711).

Dudel, C. and Myrskylä, M. (2017). Working life expectancy at age 50 in the United States and the impact of the Great Recession. Demography, 54(6):2101-2123.

Fortin, N. M. (2006). Greed, altruism, and the gender wage gap. Unpublished manuscript. University of British Columbia.

Goolsbee, A. and Syverson, C. (2020). Fear, lockdown, and diversion: Comparing drivers of pandemic economic decline. National Bureau of Economic Research.

Grossman, D. S. and Slusky, D. J. (2019). The impact of the Flint water crisis on fertility. Demography, 56(6):2005-2031.

Guerrieri, V., Lorenzoni, G., Straub, L., and Werning, I. (2020). Macroeconomic implications of COVID-19: Can negative supply shocks cause demand shortages? National Bureau of Economic Research. 
Gupta, S., Nguyen, T. D., Lozano Rojas, F., Raman, S., Lee, B., Bento, A., Simon, K. I., and Wing, C. (2020). Tracking public and private response to the COVID-19 epidemic: Evidence from state and local government actions. National Bureau of Economic Research.

Jann, B. (2008). The Blinder-Oaxaca decomposition for linear regression models. The Stata Journal, 8(4):453-479.

Kahn, L. B., Lange, F., and Wiczer, D. G. (2020). Labor demand in the time of COVID-19: Evidence from vacancy postings and UI claims. National Bureau of Economic Research.

Killewald, A. and Zhuo, X. (2019). US mothers' long-term employment patterns. Demography, 56(1):285-320.

Leibovici, F., Santacreu, A. M., and Famiglietti, M. (2020). Social distancing and contact-intensive occupations. On the economy, FED St. Louis.

Lozano-Rojas, F., Jiang, X., Montenovo, L., Simon, K. I., Weinberg, B., and Wing, C. (2020). Is the cure worse than the disease? Immediate labor market effects of COVID-19 case rates and school closures in the US. National Bureau of Economic Research.

Mongey, S. and Weinberg, A. (2020). Characteristics of workers in low work-from-home and high personal-proximity occupations. Becker Friedman Institute for Economic White Paper.

National Bureau of Economic Research (2012). U.S. business cycle expansions and contractions. Information retrieved on May 7, 2020 from www.nber.org.

Nguyen, T. D., Gupta, S., Andersen, M., Bento, A., Simon, K. I., and Wing, C. (2020). Impacts of state reopening policy on human mobility. National Bureau of Economic Research.

Oaxaca, R. L. (1973). Male-female wage differentials in urban labor markets. International Economic Review, pages 693-709.

Oaxaca, R. L. and Ransom, M. R. (1994). On discrimination and the decomposition of wage differentials. Journal of Econometrics, 61(1):5-21.

O*NET National Center for O*NET Development (2020). O*NET OnLine Help: Data collection information. Data retrieved from O*NET Online on May 6, 2020 from www.onet.org.

Rothstein, J. (2019). The Lost Generation? Scarring after the Great Recession. Goldman School of Public Policy Working Paper. 
Sakamoto, A. and Daniel, P. A. (2003). Demography of social stratification. Handbook of the Social Psychology, (Chapter 13):383-416.

Sastry, N. and Gregory, J. (2014). The location of displaced New Orleans residents in the year after Hurricane Katrina. Demography, 51(3):753-775.

Schenck-Fontaine, A. and Panico, L. (2019). Many kinds of poverty: Three dimensions of economic hardship, their combinations, and children's behavior problems. Demography, 56(6):2279-2305.

Schneider, D. and Hastings, O. P. (2015). Socioeconomic variation in the effect of economic conditions on marriage and nonmarital fertility in the United States: Evidence from the Great Recession. Demography, 52(6):1893-1915.

Seltzer, N. (2019). Beyond the Great Recession: Labor market polarization and ongoing fertility decline in the United States. Demography, 56(4):1463-1493.

The Department of Homeland Security (2020). The Department of Homeland Security guidance on Essential critical infrastructure. Data retrieved on May 6, 2020 from www.cisa.gov.

The New York Times (2020). Coronavirus (COVID-19) data in the United States. Data retrieved on April 8, 2020 from https://github.com/nytimes/covid-19-data.

U.S. Bureau of Labor Statistics (2020a). The Employment Situation for May 2020. Document retrieved on June 29, 2020 from www.bls.gov.

U.S. Bureau of Labor Statistics (2020b). Frequently asked questions: The impact of the Coronavirus (COVID-19) pandemic on The Employment Situation for April 2020. Document retrieved on May 6, 2020 from www.bls.gov.

U.S. Bureau of Labor Statistics (2020c). Frequently asked questions: The impact of the Coronavirus (COVID-19) pandemic on The Employment Situation for March 2020. Document retrieved on May 6, 2020 from www.bls.gov.

U.S. Census Bureau (2019). Current population survey: Design and methodology, technical paper 77. Technical report.

Zissimopoulos, J. and Karoly, L. A. (2010). Employment and self-employment in the wake of hurricane Katrina. Demography, 47(2):345-367. 


\section{Tables and Figures}

Figure 1: Employment Change in Three Recent Recessions - April and May

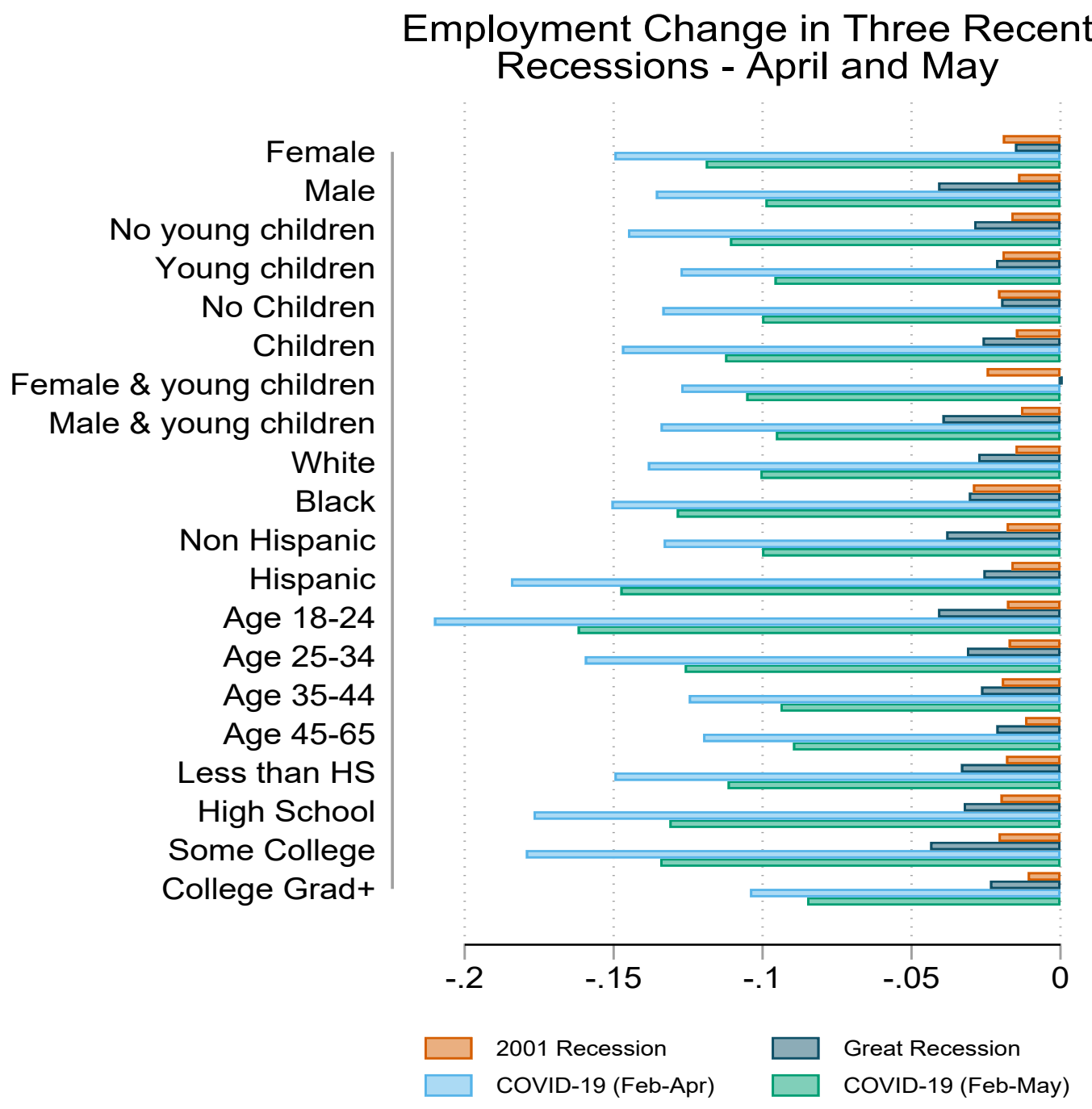

Notes: Sample consists of CPS respondents age 18-65 years. For each bar, we compute the difference in the percent of the demographic group that reports being employed and at work, between the start and end months of each recession, and between pre-COVID-19 and during COVID-19 (National Bureau of Economic Research 2012). For the COVID-19 recession, we compare both April 2020 to February 2020 and May 2020 to February 2020. The estimates were weighted using the CPS composited final weights. We seasonally adjusted the estimates including monthly fixed effects in the computation of the average subgroups employment change for the 2001 Recession and the Great Recession. 
Figure 2: Employment Change in Three Recent Recessions - April and May

\section{Employment Change in Three Recent Recessions - April and May}

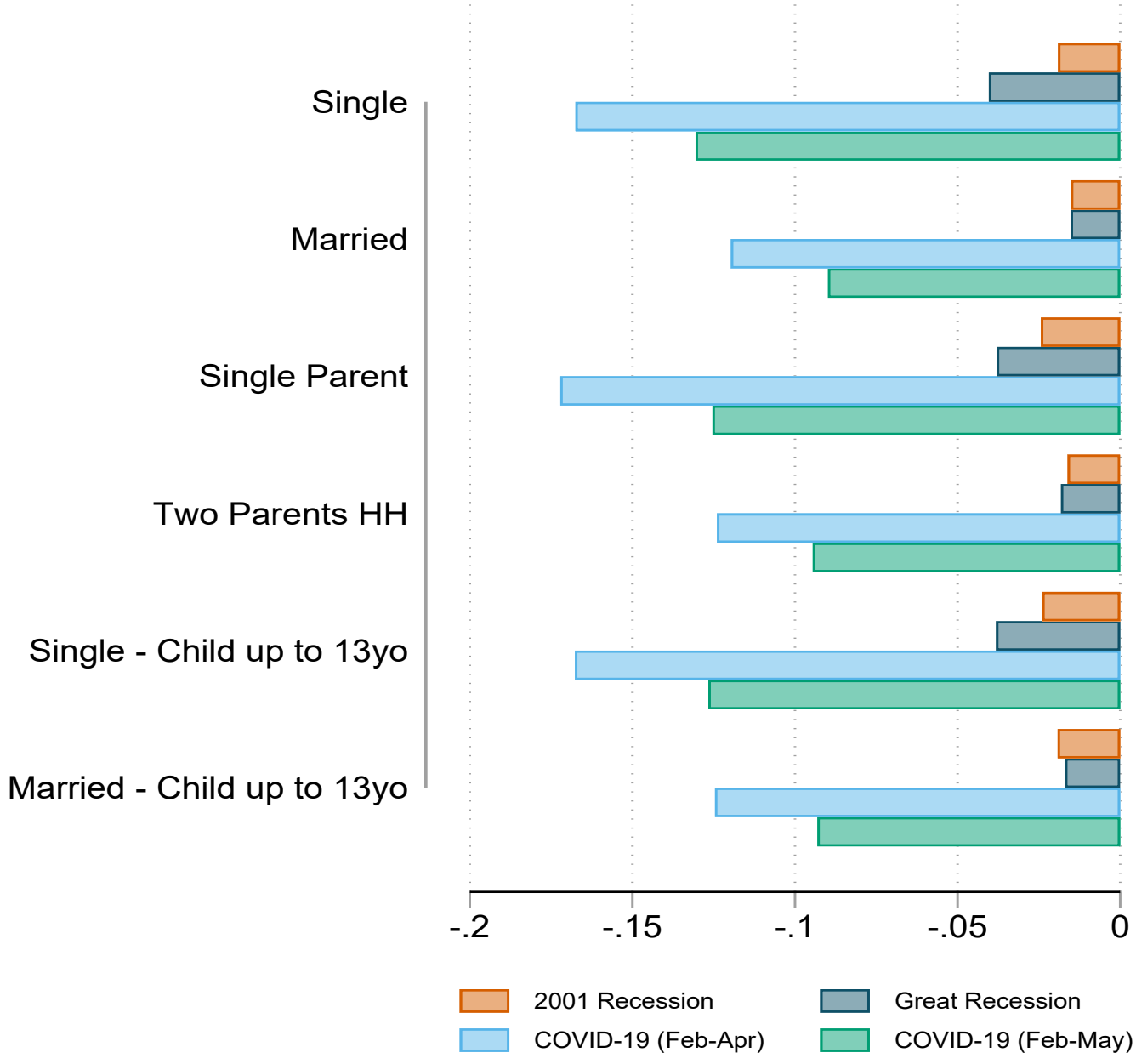

Notes: Sample consists of CPS respondents age 18-65 years. For each bar, we compute the difference in the percent of the demographic group that reports being employed and at work, between the start and end months of each recession, and between pre-COVID-19 and during COVID-19 (National Bureau of Economic Research 2012). For the COVID-19 recession, we compare both April 2020 to February 2020 and May 2020 to February 2020. The estimates were weighted using the CPS composited final weights. We seasonally adjusted the estimates including monthly fixed effects in the computation of the average subgroups employment change for the 2001 Recession and the Great Recession. 
Figure 3: Remote Work and Face to Face Indices by Demographic Group - Feburary 2020

\section{Remote Work, Face to Face, and Teleworkable Indices \\ by Demographic Group- February 2020}
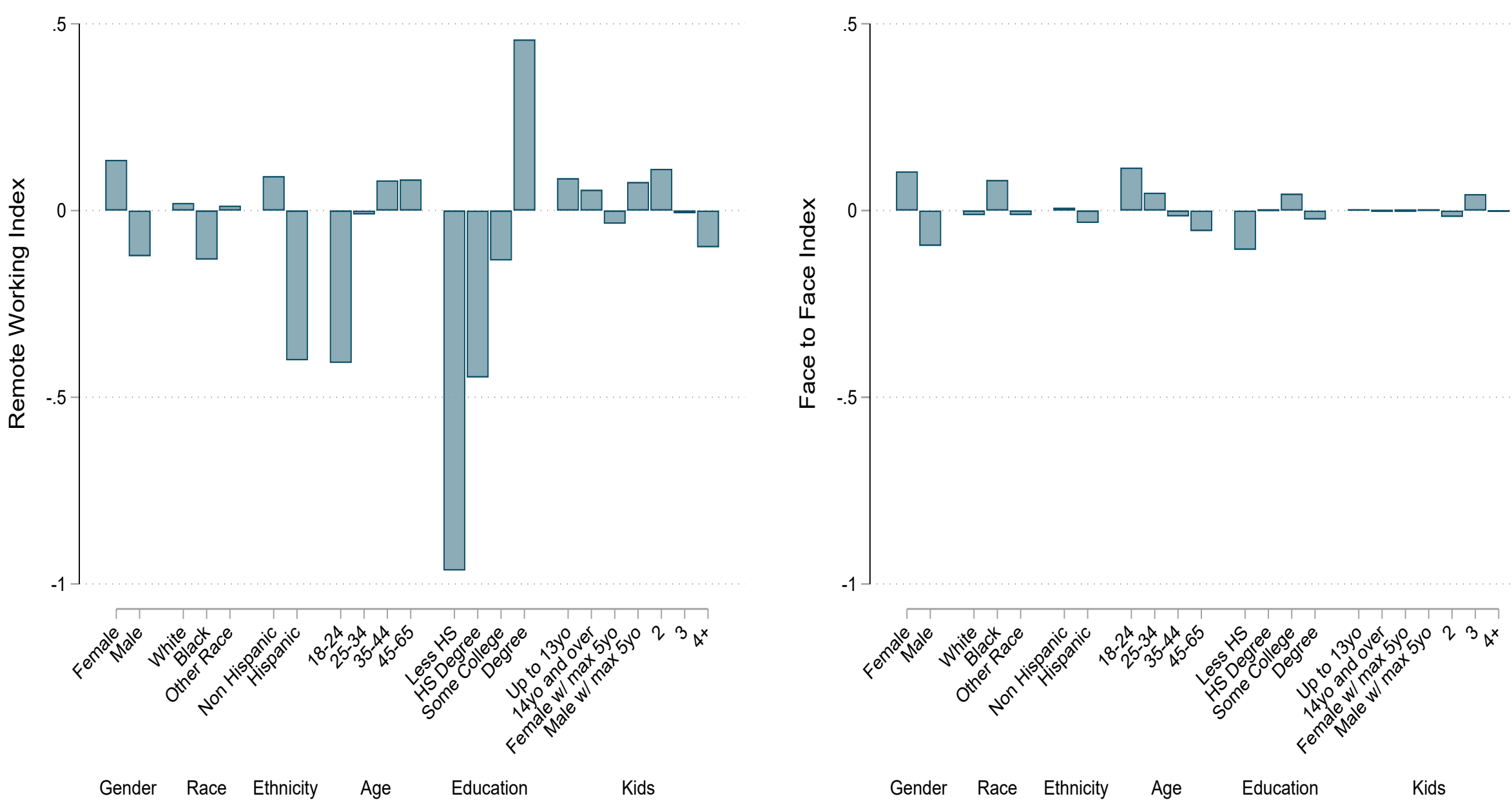

Note: Sample consists of CPS February 2020 respondents age 18-65 years in the labor force. To make the sample uniform, we drop observations with missing value for any of the covariates in any model for the month in consideration. Each index has been standardized to have mean 0 and standard deviation 1 . We compute the average of each occupation index by subgroup. Negative numbers indicate lack of that characteristic in the jobs of that group. 
Figure 4: Recent Unemployment Rate in April by Occupation Index for Remote Work and Face-to-Face

Recent Unemployment Rate in April by Occupation Index for Remote Work and Face-to-Face
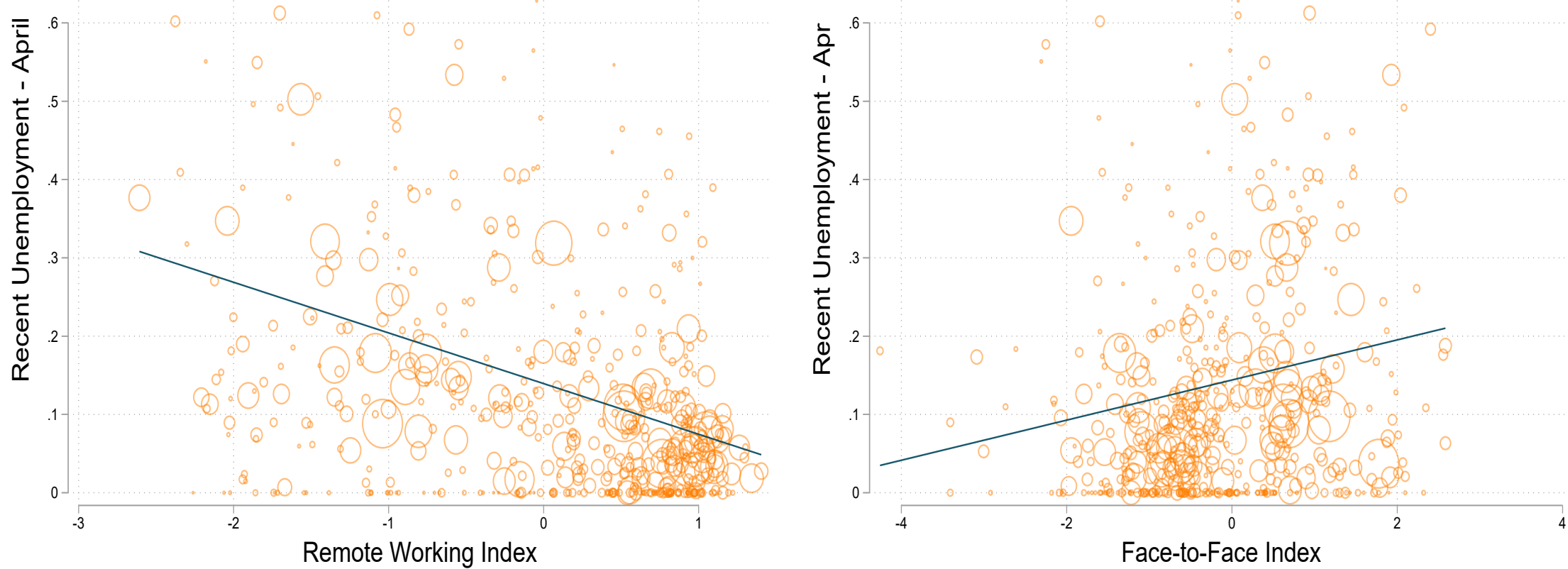

Note: Sample consists of April CPS 2020 respondents age 18-65 years in the labor force. We produce the figure using the sample of observations in the regression on column (3) of Table 1, our most detailed model, for the month considered. We compute the average percent recently unemployed in each occupation and plot that against the occupation's index value. Each occupational index has been standardized to have mean 0 and standard deviation 1 . Each bubble represents a Census occupation, with area proportional to the size of the workforce that holds that occupation in our sample. To improve readability, when plotting the bubbles we excluded from the sample the 5 occupations that, in April 2020, have recent unemployment rate above $78 \%$. However, to reproduce the line plotting the linear prediction of recently unemployed on each occupation index we do not drop these "extreme" occupations. The slope of the regression line in the left panel is -0.067 (constant $=0.139$ ), while the slope in the right panel is 0.026 (constant $=0.14$ ) 
Figure 5: Recent Unemployment Rate in May by Occupation Index for Remote Work and Face-to-Face

Recent Unemployment Rate in May by Occupation Index for Remote Work and Face-to-Face
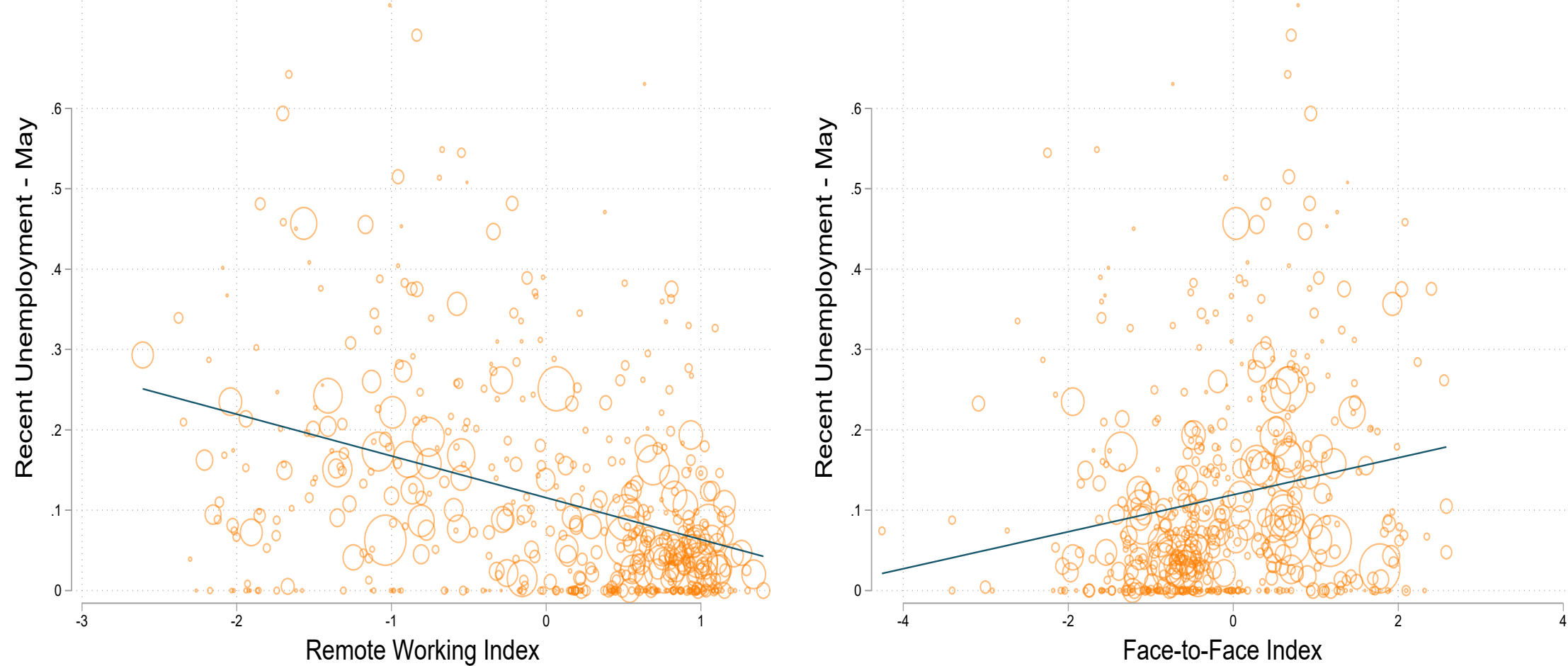

Note: Sample consists of May CPS 2020 respondents age 18-65 years in the labor force. We produce the figure using the sample of observations in the regression on column (3) of Table 1, our most detailed model, for the month considered. We compute the average percent recently unemployed in each occupation and plot that against the occupation's index value. Each occupational index has been standardized to have mean 0 and standard deviation 1 . Each bubble represents a Census occupation, with area proportional to the size of the workforce that holds that occupation in our sample. To improve readability, when plotting the bubbles we excluded from the sample the 2 occupations that, in April 2020, have recent unemployment rate above $78 \%$. However, to reproduce the line plotting the linear prediction of recently unemployed on each occupation index we do not drop these "extreme" occupations. The slope of the regression line in the left panel is -0.052 (constant $=0.116$ ), while the slope in the right panel is 0.023 (constant $=0.119$ ) 
Table 1: Cross-Sectional Models: Characteristics of the Recently Unemployed Workers

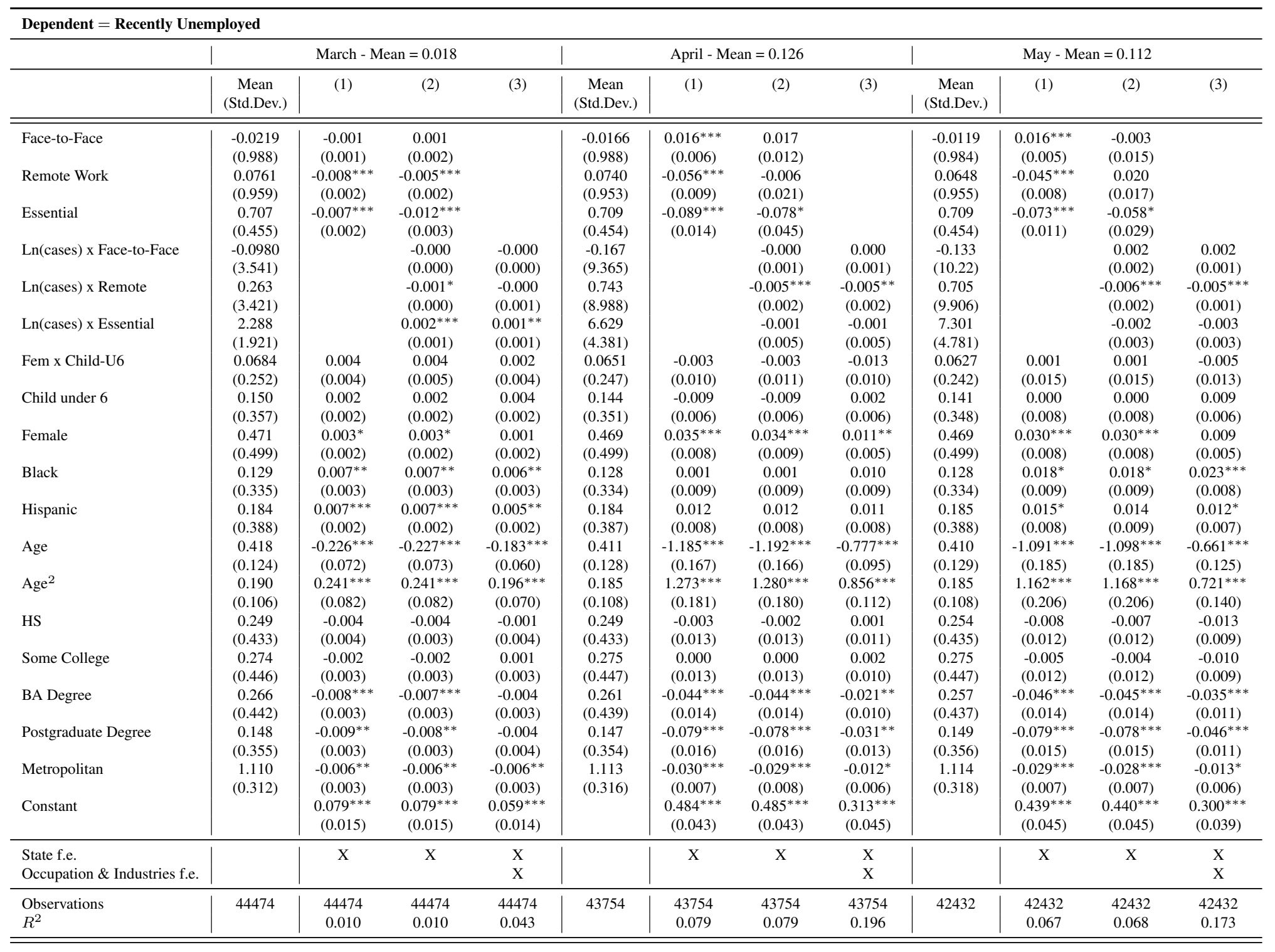

Notes: Coefficients for Equation 1 using March (left), April (middle) and May (right) 2020 CPS Data for individuals on the labor force and with recent unemployment as the dependent variable. Column (1) includes socio-demographic and job tasks' characteristics. Column (2) adds the states' epidemiological conditions as measured by their COVID-19 log exposure, interacted with occupation characteristics. Column (3) adds occupation and industries fixed effects. All models include state fixed effects. Standard errors from multi-way clustering at the state and occupation
level in parentheses. Statistical significance level: * $\mathrm{p}<0.1 ; * * \mathrm{p}<0.05 ; * * * \mathrm{p}<0.01$ 
Table 2: Cross-Sectional Models: Characteristics of the Temporary Absent Workers

\begin{tabular}{|c|c|c|c|c|c|c|c|c|c|}
\hline \multicolumn{10}{|c|}{ Dependent $=$ Employed - Absent from Work } \\
\hline & \multicolumn{3}{|c|}{ Mar - Mean $=0.037$} & \multicolumn{3}{|c|}{ April - Mean $=0.071$} & \multicolumn{3}{|c|}{ May - Mean $=0.050$} \\
\hline & (1) & $(2)$ & (3) & (1) & $(2)$ & (3) & (1) & $(2)$ & (3) \\
\hline Face-to-Face & $\begin{array}{c}0.009^{* * *} \\
(0.002)\end{array}$ & $\begin{array}{c}0.009^{* * *} \\
(0.003)\end{array}$ & & $\begin{array}{c}0.014^{* * *} \\
(0.004)\end{array}$ & $\begin{array}{c}0.001 \\
(0.014)\end{array}$ & & $\begin{array}{c}0.009^{* * *} \\
(0.003)\end{array}$ & $\begin{array}{c}0.002 \\
(0.008)\end{array}$ & \\
\hline Remote Work & $\begin{array}{c}-0.007^{* * *} \\
(0.001)\end{array}$ & $\begin{array}{c}-0.005^{* *} \\
(0.002)\end{array}$ & & $\begin{array}{c}-0.014^{* * *} \\
(0.004)\end{array}$ & $\begin{array}{l}0.017^{*} \\
(0.010)\end{array}$ & & $\begin{array}{c}-0.011^{* * *} \\
(0.003)\end{array}$ & $\begin{array}{c}0.016 \\
(0.020)\end{array}$ & \\
\hline Essential & $\begin{array}{c}-0.017^{* * *} \\
(0.005)\end{array}$ & $\begin{array}{c}-0.019^{* * *} \\
(0.007)\end{array}$ & & $\begin{array}{c}-0.034^{* * *} \\
(0.007)\end{array}$ & $\begin{array}{c}-0.034 \\
(0.025)\end{array}$ & & $\begin{array}{c}-0.019^{* * *} \\
(0.006)\end{array}$ & $\begin{array}{c}-0.053^{* * *} \\
(0.016)\end{array}$ & \\
\hline Ln(cases) x Face-to-Face & & $\begin{array}{c}-0.000 \\
(0.001)\end{array}$ & $\begin{array}{l}-0.000 \\
(0.001)\end{array}$ & & $\begin{array}{c}0.001 \\
(0.002)\end{array}$ & $\begin{array}{c}0.002 \\
(0.002)\end{array}$ & & $\begin{array}{c}0.001 \\
(0.001)\end{array}$ & $\begin{array}{c}0.001 \\
(0.001)\end{array}$ \\
\hline Ln(cases) $\times$ Remote & & $\begin{array}{c}-0.001 \\
(0.000)\end{array}$ & $\begin{array}{c}-0.001 \\
(0.001)\end{array}$ & & $\begin{array}{c}-0.003^{* * *} \\
(0.001)\end{array}$ & $\begin{array}{c}-0.002^{* *} \\
(0.001)\end{array}$ & & $\begin{array}{l}-0.003 \\
(0.002)\end{array}$ & $\begin{array}{l}-0.002 \\
(0.002)\end{array}$ \\
\hline Ln(cases) x Essential & & $\begin{array}{c}0.001 \\
(0.001)\end{array}$ & $\begin{array}{c}0.000 \\
(0.002)\end{array}$ & & $\begin{array}{c}0.000 \\
(0.003)\end{array}$ & $\begin{array}{c}-0.001 \\
(0.003)\end{array}$ & & $\begin{array}{l}0.003^{*} \\
(0.002)\end{array}$ & $\begin{array}{c}0.003 \\
(0.002)\end{array}$ \\
\hline Fem x Child-U6 & $\begin{array}{c}0.030^{* * *} \\
(0.005)\end{array}$ & $\begin{array}{c}0.030^{* * *} \\
(0.005)\end{array}$ & $\begin{array}{c}0.029^{* * *} \\
(0.005)\end{array}$ & $\begin{array}{c}0.039^{* * *} \\
(0.008)\end{array}$ & $\begin{array}{c}0.039^{* * *} \\
(0.008)\end{array}$ & $\begin{array}{c}0.037^{* * *} \\
(0.008)\end{array}$ & $\begin{array}{c}0.035^{* * *} \\
(0.005)\end{array}$ & $\begin{array}{c}0.035^{* * *} \\
(0.005)\end{array}$ & $\begin{array}{c}0.034^{* * *} \\
(0.006)\end{array}$ \\
\hline Child under 6 & $\begin{array}{c}0.003 \\
(0.005)\end{array}$ & $\begin{array}{c}0.003 \\
(0.005)\end{array}$ & $\begin{array}{c}0.003 \\
(0.005)\end{array}$ & $\begin{array}{c}0.000 \\
(0.006)\end{array}$ & $\begin{array}{c}0.000 \\
(0.006)\end{array}$ & $\begin{array}{c}0.001 \\
(0.006)\end{array}$ & $\begin{array}{c}-0.001 \\
(0.003)\end{array}$ & $\begin{array}{c}-0.001 \\
(0.003)\end{array}$ & $\begin{array}{c}-0.000 \\
(0.003)\end{array}$ \\
\hline Female & $\begin{array}{c}0.008^{* * *} \\
(0.003)\end{array}$ & $\begin{array}{c}0.008^{* * *} \\
(0.003)\end{array}$ & $\begin{array}{c}0.006^{* * *} \\
(0.002)\end{array}$ & $\begin{array}{c}0.009^{* *} \\
(0.004)\end{array}$ & $\begin{array}{l}0.008^{*} \\
(0.004)\end{array}$ & $\begin{array}{c}0.001 \\
(0.003)\end{array}$ & $\begin{array}{c}0.010^{* * *} \\
(0.003)\end{array}$ & $\begin{array}{c}0.010^{* * *} \\
(0.004)\end{array}$ & $\begin{array}{c}0.007^{* *} \\
(0.003)\end{array}$ \\
\hline Black & $\begin{array}{l}-0.000 \\
(0.004)\end{array}$ & $\begin{array}{l}-0.000 \\
(0.004)\end{array}$ & $\begin{array}{c}0.000 \\
(0.004)\end{array}$ & $\begin{array}{c}0.004 \\
(0.005)\end{array}$ & $\begin{array}{c}0.004 \\
(0.006)\end{array}$ & $\begin{array}{c}0.006 \\
(0.005)\end{array}$ & $\begin{array}{c}0.004 \\
(0.005)\end{array}$ & $\begin{array}{c}0.004 \\
(0.005)\end{array}$ & $\begin{array}{c}0.006 \\
(0.005)\end{array}$ \\
\hline Hispanic & $\begin{array}{c}0.001 \\
(0.004)\end{array}$ & $\begin{array}{c}0.001 \\
(0.004)\end{array}$ & $\begin{array}{c}0.000 \\
(0.004)\end{array}$ & $\begin{array}{l}-0.007 \\
(0.010)\end{array}$ & $\begin{array}{l}-0.007 \\
(0.010)\end{array}$ & $\begin{array}{l}-0.008 \\
(0.009)\end{array}$ & $\begin{array}{c}-0.004 \\
(0.005)\end{array}$ & $\begin{array}{l}-0.004 \\
(0.005)\end{array}$ & $\begin{array}{l}-0.003 \\
(0.004)\end{array}$ \\
\hline Age & $\begin{array}{l}-0.086 \\
(0.069)\end{array}$ & $\begin{array}{l}-0.086 \\
(0.069)\end{array}$ & $\begin{array}{c}-0.102 \\
(0.065)\end{array}$ & $\begin{array}{c}0.025 \\
(0.092)\end{array}$ & $\begin{array}{c}0.020 \\
(0.093)\end{array}$ & $\begin{array}{c}0.040 \\
(0.080)\end{array}$ & $\begin{array}{c}-0.012 \\
(0.074)\end{array}$ & $\begin{array}{l}-0.015 \\
(0.073)\end{array}$ & $\begin{array}{c}-0.053 \\
(0.068)\end{array}$ \\
\hline $\mathrm{Age}^{2}$ & $\begin{array}{l}0.144^{*} \\
(0.075)\end{array}$ & $\begin{array}{l}0.144^{*} \\
(0.075)\end{array}$ & $\begin{array}{c}0.163^{* *} \\
(0.072)\end{array}$ & $\begin{array}{c}0.039 \\
(0.107)\end{array}$ & $\begin{array}{c}0.043 \\
(0.108)\end{array}$ & $\begin{array}{c}0.028 \\
(0.092)\end{array}$ & $\begin{array}{c}0.070 \\
(0.078)\end{array}$ & $\begin{array}{c}0.073 \\
(0.078)\end{array}$ & $\begin{array}{l}0.119^{*} \\
(0.070)\end{array}$ \\
\hline HS & $\begin{array}{c}0.005 \\
(0.004)\end{array}$ & $\begin{array}{c}0.005 \\
(0.004)\end{array}$ & $\begin{array}{c}0.005 \\
(0.004)\end{array}$ & $\begin{array}{c}0.005 \\
(0.008)\end{array}$ & $\begin{array}{c}0.005 \\
(0.008)\end{array}$ & $\begin{array}{c}0.009 \\
(0.009)\end{array}$ & $\begin{array}{c}-0.005 \\
(0.008)\end{array}$ & $\begin{array}{c}-0.004 \\
(0.008)\end{array}$ & $\begin{array}{c}-0.004 \\
(0.008)\end{array}$ \\
\hline Some College & $\begin{array}{r}0.008^{* *} \\
(0.004)\end{array}$ & $\begin{array}{c}0.009^{* *} \\
(0.004)\end{array}$ & $\begin{array}{r}0.007^{* *} \\
(0.003)\end{array}$ & $\begin{array}{l}-0.006 \\
(0.010)\end{array}$ & $\begin{array}{l}-0.006 \\
(0.010)\end{array}$ & $\begin{array}{c}0.001 \\
(0.010)\end{array}$ & $\begin{array}{c}0.004 \\
(0.008)\end{array}$ & $\begin{array}{c}0.005 \\
(0.009)\end{array}$ & $\begin{array}{c}0.004 \\
(0.008)\end{array}$ \\
\hline BA Degree & $\begin{array}{c}0.010^{* *} \\
(0.005)\end{array}$ & $\begin{array}{r}0.010^{* *} \\
(0.005)\end{array}$ & $\begin{array}{c}0.009^{* *} \\
(0.004)\end{array}$ & $\begin{array}{c}-0.030^{* * *} \\
(0.010)\end{array}$ & $\begin{array}{c}-0.030^{* * *} \\
(0.010)\end{array}$ & $\begin{array}{l}-0.015 \\
(0.011)\end{array}$ & $\begin{array}{l}-0.013 \\
(0.008)\end{array}$ & $\begin{array}{l}-0.013 \\
(0.008)\end{array}$ & $\begin{array}{l}-0.008 \\
(0.007)\end{array}$ \\
\hline Posgraduate Degree & $\begin{array}{c}0.000 \\
(0.005)\end{array}$ & $\begin{array}{c}0.001 \\
(0.005)\end{array}$ & $\begin{array}{l}-0.003 \\
(0.006)\end{array}$ & $\begin{array}{c}-0.050^{* * *} \\
(0.011)\end{array}$ & $\begin{array}{c}-0.050^{* * *} \\
(0.011)\end{array}$ & $\begin{array}{c}-0.026^{* *} \\
(0.012)\end{array}$ & $\begin{array}{c}-0.029^{* * *} \\
(0.009)\end{array}$ & $\begin{array}{c}-0.028^{* * *} \\
(0.009)\end{array}$ & $\begin{array}{c}-0.015^{* *} \\
(0.006)\end{array}$ \\
\hline Metropolitan & $\begin{array}{c}-0.005^{*} \\
(0.003)\end{array}$ & $\begin{array}{r}-0.005^{*} \\
(0.003)\end{array}$ & $\begin{array}{c}-0.005^{* *} \\
(0.002)\end{array}$ & $\begin{array}{l}-0.009 \\
(0.008)\end{array}$ & $\begin{array}{l}-0.008 \\
(0.008)\end{array}$ & $\begin{array}{l}-0.003 \\
(0.008)\end{array}$ & $\begin{array}{l}-0.003 \\
(0.005)\end{array}$ & $\begin{array}{l}-0.003 \\
(0.005)\end{array}$ & $\begin{array}{c}0.002 \\
(0.005)\end{array}$ \\
\hline Constant & $\begin{array}{c}0.051^{* * *} \\
(0.014)\end{array}$ & $\begin{array}{c}0.051^{* * *} \\
(0.014)\end{array}$ & $\begin{array}{c}0.043^{* * *} \\
(0.013)\end{array}$ & $\begin{array}{c}0.098^{* * *} \\
(0.020)\end{array}$ & $\begin{array}{c}0.099^{* * *} \\
(0.020)\end{array}$ & $\begin{array}{c}0.061^{* *} \\
(0.029)\end{array}$ & $\begin{array}{c}0.061^{* * *} \\
(0.015)\end{array}$ & $\begin{array}{c}0.061^{* * *} \\
(0.015)\end{array}$ & $\begin{array}{l}0.028^{*} \\
(0.016)\end{array}$ \\
\hline $\begin{array}{l}\text { State f.e. } \\
\text { Occupation \& Industries f.e. }\end{array}$ & $\mathrm{X}$ & $\mathrm{X}$ & $\begin{array}{l}X \\
X\end{array}$ & $\mathrm{X}$ & $\mathrm{X}$ & $\begin{array}{l}X \\
X\end{array}$ & $\mathrm{X}$ & $X$ & $\begin{array}{l}X \\
X\end{array}$ \\
\hline $\begin{array}{l}\text { Observations } \\
R^{2}\end{array}$ & $\begin{array}{l}44474 \\
0.012\end{array}$ & $\begin{array}{l}44474 \\
0.012\end{array}$ & $\begin{array}{l}44474 \\
0.042\end{array}$ & $\begin{array}{l}43754 \\
0.023\end{array}$ & $\begin{array}{l}43754 \\
0.023\end{array}$ & $\begin{array}{c}43754 \\
0.074\end{array}$ & $\begin{array}{c}42432 \\
0.016\end{array}$ & $\begin{array}{c}42432 \\
0.016\end{array}$ & $\begin{array}{c}42432 \\
0.062\end{array}$ \\
\hline
\end{tabular}

Notes: Coefficients for Equation 1 using March (left), April (middle) and May (right) 2020 CPS Data for individuals on the labor force and with temporary absent from work as the dependent variable. Column (1) includes socio-demographic and job tasks' characteristics. Column (2) adds the states' epidemiological conditions as measured by their log exposure, interacted with occupation characteristics. Column (3) adds occupation and industries fixed effects. All models include state fixed effects. Standard errors from multi-way clustering at the state and occupation level in parentheses. Statistical significance level: * $\mathrm{p}<0.1 ; * * \mathrm{p}<0.05 ; * * * \mathrm{p}<0.01$ 
Figure 6: Oaxaca-Blinder Decomposition for April: A Graphical Representation

\section{$\underline{\text { Model A }}$}

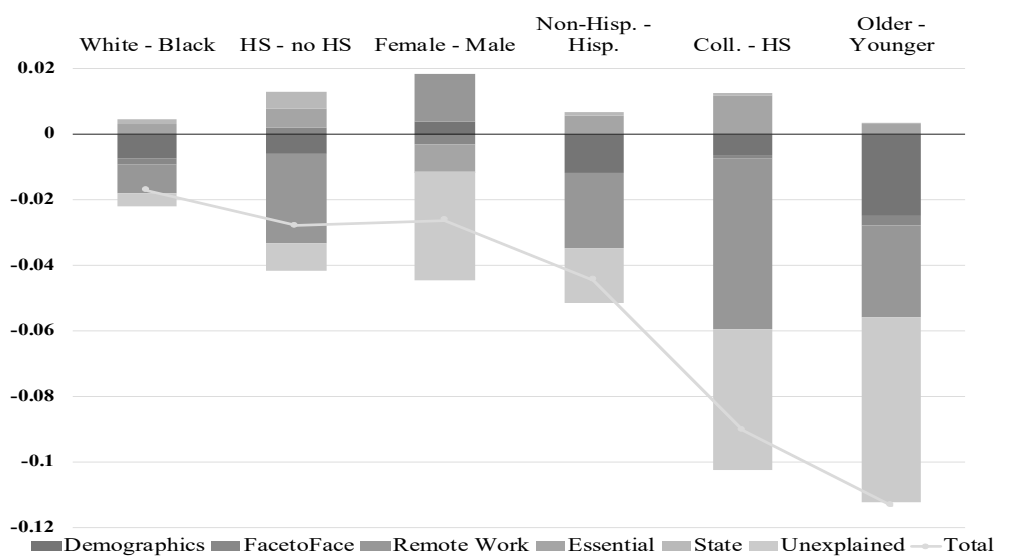

\section{Model B}

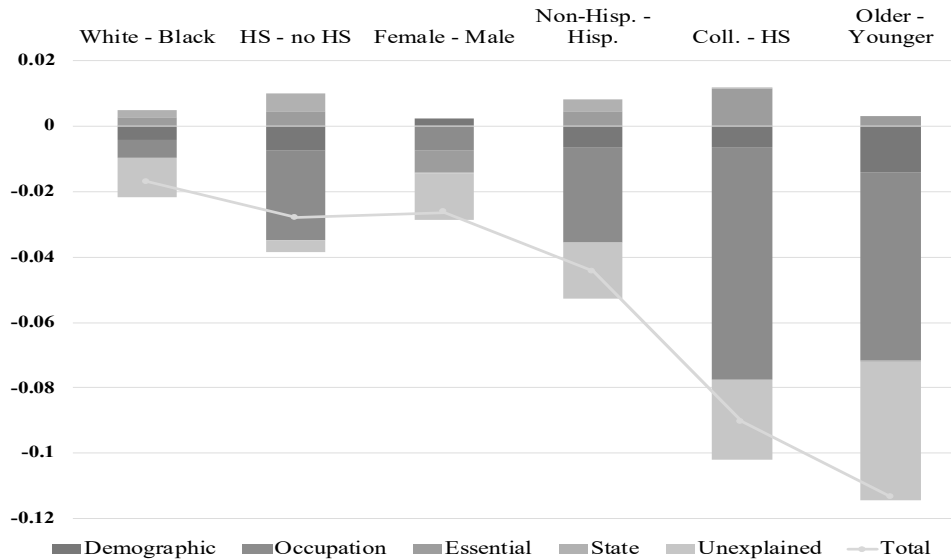

\section{Model C}

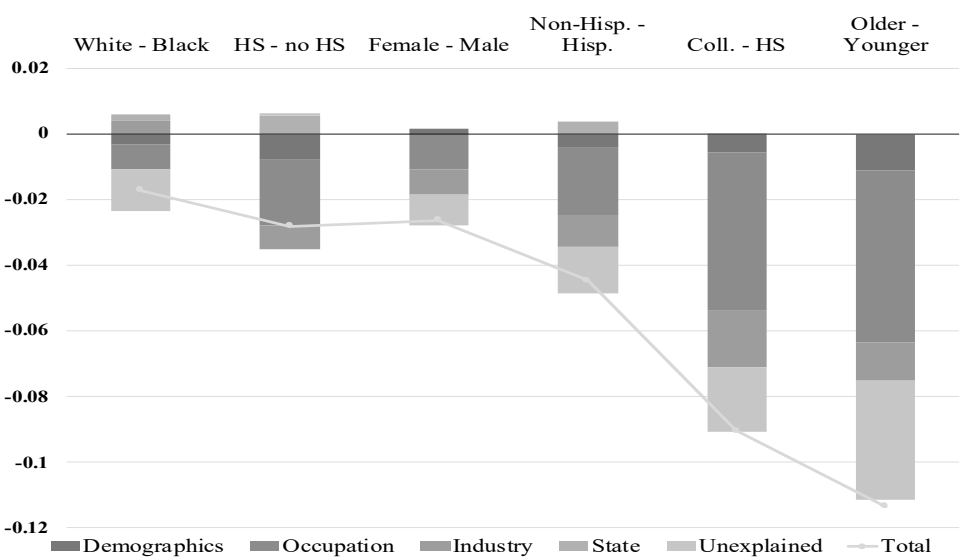

Note: The three figures are the graphical representation of the Oaxaca decomposition estimates shown in Table A13.1. These are obtained through three different models, all of which include socio-demographic controls (i.e. age, gender, race, ethnicity, and education), state fixed effects, and a dummy for the presence of children under 6. Model A includes the Face-to-Face, Remote Work, and Essential Job indices. Model B adds a full set of 523 occupation dummies. Model C includes a full set of 261 industry dummies, and reports the share of each gap explained by sorting into industries classified as Essential vs Non-essential. Each shaded area represents the share that is, depending on the color, explained by the different sets of variables reported in the legend. 
Figure 7: Oaxaca-Blinder Decomposition for May: A Graphical Representation

\section{$\underline{\text { Model A }}$}

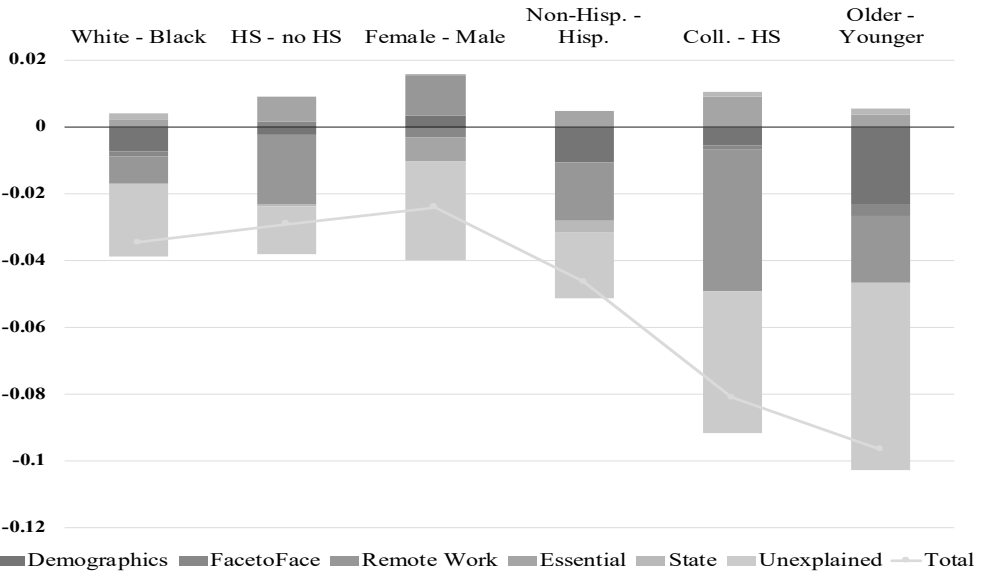

\section{Model B}

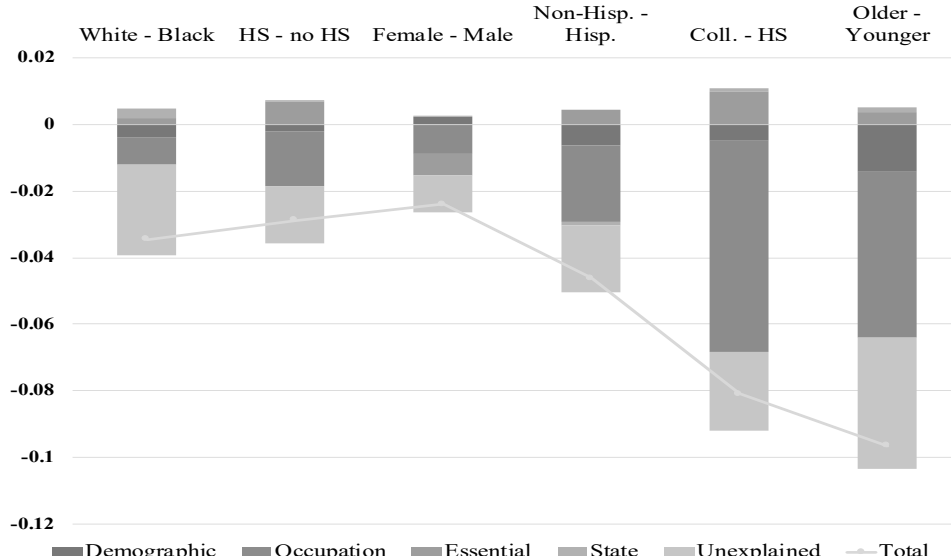

\section{Model C}

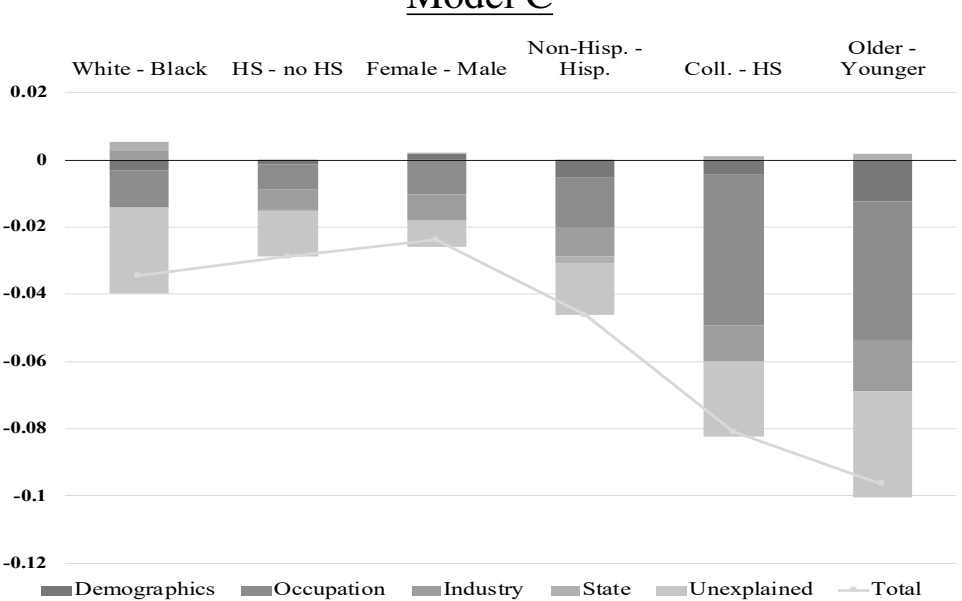

Note: The three figures are the graphical representation of the Oaxaca decomposition estimates shown in Table A13.3 and obtained through three different models. These are obtained through three different models, all of which include socio-demographic controls (i.e. age, gender, race, ethnicity, and education), state fixed effects, and a dummy for the presence of children under 6. Model A includes the Face-to-Face, Remote Work, and Essential Job indices. Model $\mathrm{B}$ adds a full set of 523 occupation dummies. Model C includes a full set of 261 industry dummies, and report the share of each gap explained by sorting into industries classified as Essential vs Non-essential. Each shaded area represents the share that is, depending on the color, explained by the different sets of variables reported in the legend. 


\section{A Appendix}

\section{Contents}

A.1 CPS Data - Further Details . . . . . . . . . . . . . . . App. 1

A.2 Employment Change and Recent Unemployment . . . . . . . . . . . . App. 3

A.3 O*NET Data - Further Details . . . . . . . . . . . . . . . App. 5

A.4 Definitions for Occupation and Industry Characteristics . . . . . . . . . . . . App. 6

A.5 BLS: Employment Rates Over Time . . . . . . . . . . . . . . . . App. 10

A.6 Teleworkable Index by Socio-Demographic Subgroups . . . . . . . . . . . . . App. 11

A.7 Association of Job Attributes and Employment Outcomes Over Time . . . . . . . . App. 12

A.8 Regressions: the Role of COVID-19 Mortality Risk . . . . . . . . . . . . . . . . . App. 14

A.9 Additional Labor Market Outcome: Combined Not at Work . . . . . . . . . . . . . App. 17

A.10 Regressions: Results using 2019 Data . . . . . . . . . . . . . . . . . . App. 18

A.11 Sensitivity to Definition of "Recent" Unemployment in Weeks . . . . . . . . . . App. 20

A.12 Sensitivity to definitions of Face-to-Face and Remote Work . . . . . . . . . . . . . App. 23

A.13 Oaxaca-Blinder Decomposition: Additional Exercises . . . . . . . . . . . . . App. 25

\section{A.1 CPS Data - Further Details}

We build the recent unemployment variable using a "moving window" of weeks depending on the month under consideration. That is, for March 2020, a worker is coded as recently unemployed if he/she declares to have been in that status for at most 5 weeks. For April 2020, we consider as recently unemployed workers who are unemployed on survey week, and have been unemployed for at most 10 weeks. For May 2020, recently unemployed workers are individuals who claim to be unemployed and have been so for at most 14 weeks. When creating this variable, we exclude individuals who list themselves as currently out of the labor force. During March 2020, 1.8\% of those between 18 and 65 years old in our sample are recently unemployed according to our definition. In April, the number of those aged 18 and above in the labor force reported being unemployed at the time and who had lost their job sometime in the last 10 weeks spiked to $11.8 \%$. During May, $10.3 \%$ of the workers were recently unemployed (i.e. unemployed for at most 14 weeks).

As mentioned in Section 3 of the paper, the employed-but-absent category of workers that the CPS identifies needs particular attention in analyses of labor market during the COVID-19 epidemic. This is due to mostly three explanations. First, some employers released workers intending to rehire them (Bogage 2020; Borden 2020). Second, some workers may have requested leave from their schedule to provide dependent care or to care for a sick household member. Third, there was a misclassification problem during the data collection of the March, April and May 2020 CPS: rather than being rightly coded as recently laid off or unemployed, some workers out of work due 
to the epidemic were classified as employed-but-absent (U.S. Bureau of Labor Statistics (2020c), U.S. Bureau of Labor Statistics (2020b) and U.S. Bureau of Labor Statistics (2020a)).

As a consequence, in our sample, the employed-but-absent share group rose by $32 \%$ from February to March 2020, by $113 \%$ from February to April, and by $50 \%$ from February to May, 2020. We show separate results for this employment outcome in most of our analysis. 


\section{A.2 Employment Change and Recent Unemployment}

The graphs on the left of both Panels of Appendix Figure A2.1 show the average change in employment rates from February 2020 to April 2020 (Panel A) and to May 2020 (Panel B) by demographic sub-population. The graphs on the right show the fraction of labor force participants who became unemployed recently as of the April CPS (Panel A) and May CPS (Panel B) reference weeks. The figure shows that changes in employment and recent unemployment rates convey similar information. Both employment outcomes are worse for younger workers, less educated workers, Hispanics, females, and workers with their own children in the household. Given the similarity between the two measures, we focus on recent unemployment. 
Figure A2.1

\section{Change in Employment and Recent Unemployment During Covid-19}

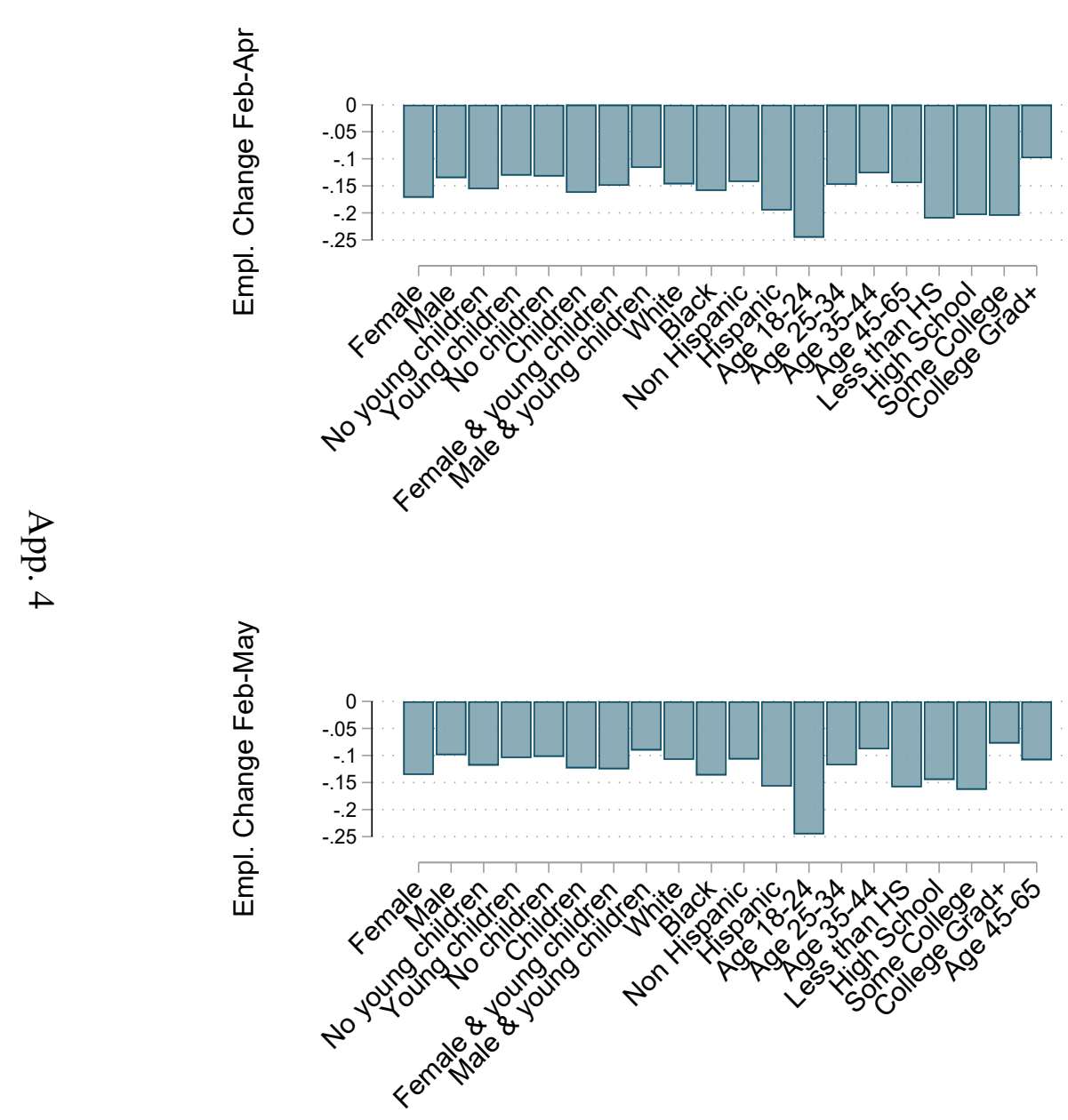

April

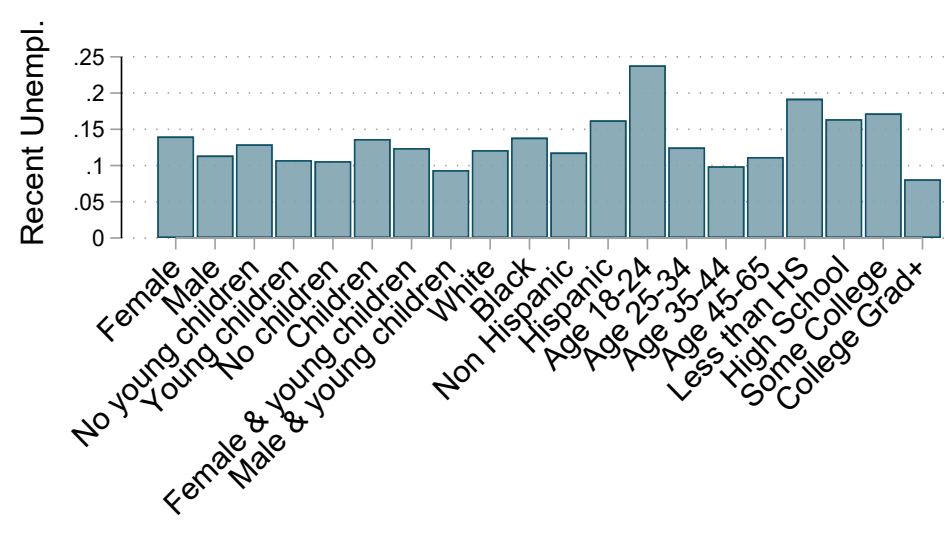

May

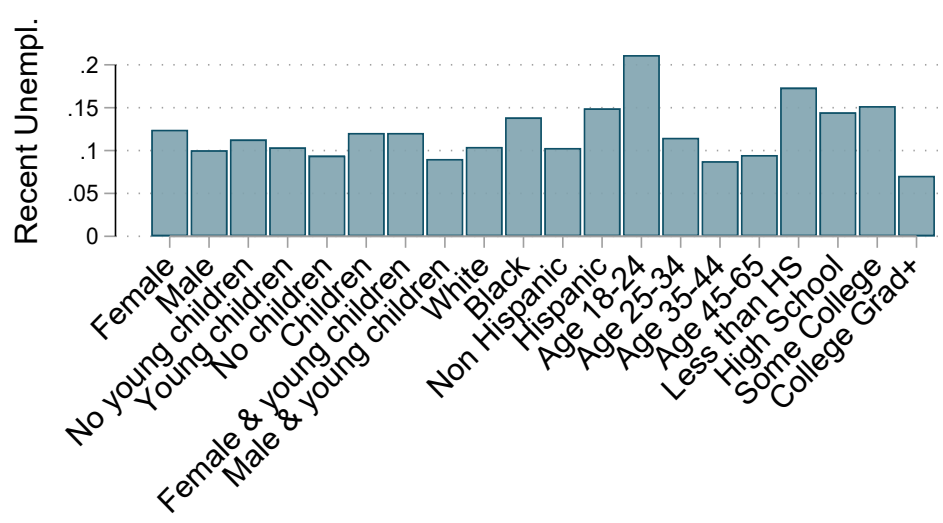

Note: In Panel A, Employment Change is computed as the February employment rate minus the April rate. Recently Unemployed is reported only from the April CPS (coded as Recently Unemployed if unemployed in April, and became unemployed at most 10 weeks before the CPS April survey week).

In Panel B, Employment Change is computed as the February employment rate minus the May rate. Recently Unemployed is reported only from the May CPS (coded as Recently Unemployed if unemployed in April, and became unemployed at most 14 weeks before the CPS May survey week). In both panels, the change in employment is computed excluding workers who are employed but absent from work. To uniform the sample across the entire analysis, we drop observations with missing value for any of the covariates in our most specified regression model for the month in consideration. 


\section{A.3 O*NET Data - Further Details}

In the $\mathrm{O}^{*}$ NET datasets, answers on occupation characteristics are typically provided on a 1-5 scale, where 1 indicates that a task is performed rarely or is not important to the job, and 5 indicates that the task is performed regularly or is important to the job. To measure the extent to which an occupation involves tasks that may become riskier or more valuable during the COVID-19 epidemic, we developed indices for Face-to-Face interactions and the potential for Remote Work.

The value of each of these two indices for an occupation is a simple average of the O*NET questions we used (listed in table A4.1). We standardized the indices to have a mean of zero and a standard deviation of one in our sample.

The O*NET data classify occupations using SOC codes and the CPS data classifies occupation codes using Census Occupation codes. We cross-walked the two data sets to link the O*NET Face-to-Face and Remote Work indices with the CPS microdata. The April CPS contains workers from 526 unique Census Occupations. We were able to link the index variables to 520 occupation codes, leaving only 5 occupations with missing indices. For May, we linked 515 occupations out of 524 total for that month ${ }^{13}$

\footnotetext{
${ }^{13}$ We were not able to link an O*Net Face-to-Face or Remote Work index to workers in Census Occupation Codes 1240 (Miscellaneous mathematical science occupations) and 9840 (Armed Forces).
} 


\section{A.4 Definitions for Occupation and Industry Characteristics}

Below we provide details on how we built the occupation indexes, by reporting, on Table A4.1, the questions that we used to generate them. We also show the questions that go in the teleworkable index by Dingel and Neiman (2020). Moreover, we provide rankings of occupation along our Face-to-Face and Remote Working variables. In particular, Table A4.2 provides the 5 percent top and bottom occupations for their reliance on Face-to-Face activities. Given that most of the top 5\% Face-to-Face occupations are medical or healthcare-related, and these occupations are heavily essential during the pandemic, we also show a list that excludes medical occupations. Instead, Table A4.3 reports the 5 percent top and bottom occupations for how feasible it is for workers to perform activities remotely. Finally, Table A4.4 reports the industry sectors that are defined as essential based on Blau et al. (2020).

\section{Table A4.1: O*Net Index related Questions}

\begin{tabular}{cl}
\hline \hline \multicolumn{1}{c}{ Index } & \multicolumn{1}{c}{ O*Net Items } \\
\hline \multirow{2}{*}{ Face to Face } & $\begin{array}{l}\text { How often do you have face-to-face discussions with individuals or teams in this job? } \\
\text { To what extent does this job require the worker to perform job tasks in close physical proximity to other } \\
\text { people? }\end{array}$ \\
\hline \multirow{2}{*}{ Remote Work } & $\begin{array}{l}\text { How often do you use electronic mail in this job? } \\
\text { How often does the job require written letters and memos? } \\
\text { How often do you have telephone conversations in this job? }\end{array}$ \\
\hline \hline
\end{tabular}

Note: The O*Net "Work Context" module (2019 version: available www.onetcenter.org) reports summary measures from worker surveys of the tasks involved in 968 occupations using the Standard Occupation Code, 2010 version). The questions use a 1-5 scale, where 1 indicates rare/not important. We developed two indices: (1) Face-to-Face interactions, (2) the potential for Remote Work. The value of each index for an occupation is a simple average $\mathrm{O} * \mathrm{Net}$ questions listed in the table.

\begin{tabular}{ll}
\hline \hline Teleworkable & \\
\hline O*Net Work Context \\
\hline Average respondent says they use email less than once per month \\
Average respondent says they deal with violent people at least once a week \\
Majority of respondents say they work outdoors every day \\
Average respondent says they are exposed to diseases or infection at least once a week \\
Average respondent says they are exposed to minor burns, cuts, bites, or stings at least once a week \\
Average respondent says they spent majority of time walking or running \\
Average respondent says they spent majority of time wearing common or specialized protective or safety \\
equipment \\
O*Net Generalized Work Activities \\
Performing General Physical Activities is very important \\
Handling and Moving Objects is very important \\
Controlling Machines and Processes [not computers nor vehicles] is very important \\
Operating Vehicles, Mechanized Devices, or Equipment is very important \\
Performing for or Working Directly with the Public is very important \\
Repairing and Maintaining Mechanical Equipment is very important \\
Repairing and Maintaining Electronic Equipment is very important \\
Inspecting Equipment, Structures, or Materials is very important \\
\hline
\end{tabular}

Note: The Teleworkable index has been built by Dingel \& Neiman (2020). The authors use the O*Net "Work Context" and the "Generalized Work Activities" modules. If any of the above conditions in the Work Context or in the Generalized Work Activities is true they code that occupation as one that cannot be performed at home. 
Table A4.2: Top and Bottom Occupations: Face-to-Face

\begin{tabular}{|c|c|c|}
\hline \multirow[t]{2}{*}{ Bottom 5\% } & Top 5\% & Top 5\% \\
\hline & Including Medical Professions & Excluding Medical Professions \\
\hline Logging Workers & Other Physicians & Special Education Teachers \\
\hline Moving Workers & Surgical Technologists & Hairdressers, Hairstylists, Cosmetologists \\
\hline Material Collectors & Nurse Anesthetists & Dancers and Choreographers \\
\hline Artists & Occupational Therapists & Supervisors of Food Preparation and Serving \\
\hline Writers and Authors & Special Education Teachers & Electrical and Electronics Repairers \\
\hline Meter Readers, Utilities & Podiatrists & Teaching Assistants \\
\hline Transportation Workers & Licensed Vocational Nurses & Flight Attendants \\
\hline Audiovisual equipment workers & Hairdressers, and Cosmetologists & Bailiffs \\
\hline Pressers, Textile, Garment & Optometrists & Pipelayers \\
\hline Entertainment Attendants & Health Technicians & Chefs and Head Cooks \\
\hline Parking Enforcement & Occupational Therapy Aides & Rail-Track and Maintenance Operators \\
\hline Bill and Account Collectors & Paramedics & Actors \\
\hline Medical Transcriptionists & Emergency Medical Technicians & Barbers \\
\hline Economists & Dental Assistants & Nuclear Technicians \\
\hline Market Research Analysts & Cardiovascular Technicians & Ticket Agents and Travel Clerks \\
\hline Astronomers and Physicists & Skincare Specialists & Transportation Security Screeners \\
\hline Job Analysis Specialists & Radiation Therapists & Education and Childcare Administrators \\
\hline Personal Financial Advisors & Respiratory Therapists & Food Service Managers \\
\hline Maids and Housekeeping Cleaners & Dancers and Choreographers & Tellers \\
\hline Agricultural Workers & Physical Therapist Aides & Electrical Installers and Repairers \\
\hline Food and Tobacco Roasting, Baking & Surgeons & Graders and Sorters \\
\hline File Clerks & Chiropractors & Supervisors of Police and Detectives \\
\hline Printing Press Operators & Dental Hygienists & Ushers, Lobby Attendants \\
\hline Petroleum Engineers & Dentists & Entertainment and Recreation Managers \\
\hline Truck and Tractor Operators & Physical Therapists & Meeting, Convention, and Event Planners \\
\hline Physical Scientists, All Other & Therapists, All Other & Aircraft Pilots and Engineers \\
\hline
\end{tabular}


Table A4.3: Top and Bottom Occupations: Remote Working

\begin{tabular}{ll}
\hline Bottom 5\% & Top 5\% \\
\hline Other Assemblers and Fabricators & Executive Secretaries and Executive Administrative Assistants \\
Dishwashers & Travel Agents \\
Sewing Machine Operators & Healthcare Social Workers \\
Metal Furnace Operators, Tenders, Pourers, and Casters & Purchasing Managers \\
Upholsterers & Chief Executives \\
Packers and Packagers, Hand & Landscape Architects \\
Pressers, Textile, Garment, and Related Materials & Social and Community Service Managers \\
Electrical, Electronics, and Electromechanical Assemblers & Medical and Health Services Managers \\
Welding, Soldering, and Brazing Workers & Public Relations and Fundraising Managers \\
Laundry and Dry-Cleaning Workers & Advertising Sales Agents \\
Painting Workers & First-Line Supervisors of Non-Retail Sales Workers \\
Furniture Finishers & Lodging Managers \\
Graders and Sorters, Agricultural Products & Environmental Engineers \\
Machine Tool Setters, Operators, and Tenders & Real Estate Brokers and Sales Agents \\
Maids and Housekeeping Cleaners & Human Resources Managers \\
Print Binding and Finishing Workers & Architects, Except Landscape and Naval \\
Packaging and Filling Machine Operators and Tenders & Sales Managers \\
Machine Feeders and Offbearers & Paralegals and Legal Assistants \\
Textile Machine Setters, Operators, and Tenders & Credit Authorizers, Checkers, and Clerks \\
Logging Workers & Property, Real Estate, and Community Association Managers \\
Transportation Service Attendants & Urban and Regional Planners \\
Passenger Attendants & Human Resources Workers \\
Cutting, Punching, and Press Machine Setters and Operators & Fundraisers \\
Other Metal Workers and Plastic Workers & Legal Secretaries and Administrative Assistants \\
Sawing Machine Setters, Operators, and Tenders, Wood & Lawyers \\
Underground Mining Machine Operators & Claims Adjusters, Appraisers, Examiners, and Investigators
\end{tabular}


Table A4.4: Industry Sectors and Categories defined as Essential

\begin{tabular}{|c|c|c|}
\hline Sector & Sector Name & Examples \\
\hline 11 & $\begin{array}{l}\text { Agriculture, Forestry, Fishing and } \\
\text { Hunting }\end{array}$ & $\begin{array}{l}\text { Crop production; Animal production; Forestry; Logging; Fishing, Hunting and trapping; Agriculture and forestry support } \\
\text { activities }\end{array}$ \\
\hline 21 & $\begin{array}{l}\text { Mining, Quarrying, and Oil and Gas } \\
\text { Extraction }\end{array}$ & $\begin{array}{l}\text { Oil and gas extraction; Coal mining; Metal ore mining; Nonmetallic mineral mining and quarrying; Not specified mining; } \\
\text { Mining support activities }\end{array}$ \\
\hline 22 & Utilities & $\begin{array}{l}\text { Electric power generation, transmission and distribution; Natural gas distribution; Electric and gas, and other combina- } \\
\text { tions; Water, steam, air-conditioning, and irrigation,; Sewage; Other not specified }\end{array}$ \\
\hline 23 & Construction & All in construction \\
\hline 31-33 & Manufacturing & $\begin{array}{l}\text { All Food manufacturing; All Animal food manufacturing; Industries: All in Paper related; Petroleum; Rubber \& Tires; } \\
\text { Pharma; Plastics; Chemicals; Pottery and ceramics; Cement; Glass; Iron; Aluminum; Nonferrous metal; Foundries; } \\
\text { Forgings; Cutlery; Coating; All machinery and equipment manufacturing; Household appliance manufacturing; Mo- } \\
\text { tor vehicles \& parts; Aircraft \& parts; Railroad; Ship and boats; other transportation; Sawmills; Wood manufacturing; } \\
\text { Medical Supplies. }\end{array}$ \\
\hline 42 & Wholesale Trade & $\begin{array}{l}\text { Paper; Machinery and equipment; Hardware; Household appliances; Lumber and construction; Grocery and related } \\
\text { products; Drugs; sundries and chemical and allied products; Farm product raw material; Petroleum products; Alcoholic } \\
\text { beverages; Farm supplies; other non-durable goods; electronic markets, agents and brokers. }\end{array}$ \\
\hline 44-45 & Retail Trade & $\begin{array}{l}\text { Automotive parts and accessories; Electronics; Building materials; Lawn and garden equipment; Grocery stores; Super- } \\
\text { markets; Convenience stores; Specialty food stores; Beer, wine and liquor stores; Pharmacies and drug stores; Health and } \\
\text { personal care stores; Gas stations; General merchandise stores; Electronic shopping and mail-order houses; Fuel dealers. }\end{array}$ \\
\hline 48-49 & Transportation and Warehousing & $\begin{array}{l}\text { Air, Rail T., Water, Truck, Transportation; Bus service and urban transit; Taxis; Pipeline transportation; Services inciden- } \\
\text { tal to transportation; Postal Service; Couriers; Warehousing and storage. }\end{array}$ \\
\hline 51 & Information & $\begin{array}{l}\text { Newspapers, periodicals, book and directory publishers; Software publishers; Broadcasting; Internet publishing and } \\
\text { broadcasting; Wired telecommunication carriers; Telecomm.; Data processing, hosting and related; Other information } \\
\text { services, except libraries and archives. }\end{array}$ \\
\hline 52 & Finance and Insurance & $\begin{array}{l}\text { Banking; Saving institutions; Credit Unions; Non-depository credit activities; Securities, commodities, funds, trusts; } \\
\text { Other financial investments, Insurance carriers. }\end{array}$ \\
\hline 53 & Real Estate and Rental and Leasing & Real State; Lessors, agents brokers; Property managers; Appraisers offices; Other related. \\
\hline 54 & $\begin{array}{l}\text { Professional, Scientific, and Techni- } \\
\text { cal Services }\end{array}$ & $\begin{array}{l}\text { Accounting, tax preparation, bookkeeping and payroll services; Management, scientific and technical consulting services; } \\
\text { Scientific research and development; Veterinary }\end{array}$ \\
\hline 56 & Admin. \& Waste Manag. Services & Security and investigation; Services to buildings; landscaping; waste management and remediation \\
\hline 62 & Health Care and Social Assistance & $\begin{array}{l}\text { Physicians, dentists, chiropractors, optometrists, other; Outpatient care centers; Home health care services; Other health } \\
\text { care; Hospitals; Psychiatric and substance abuse hospitals; Nursing care facilities; Residential care facilities; Individual } \\
\text { and family services; Child day care. }\end{array}$ \\
\hline 72 & Accommodation and Food Services & Traveler accommodation; Restaurants and other food services. \\
\hline 81 & $\begin{array}{l}\text { Other Services (except Public Ad- } \\
\text { ministration) }\end{array}$ & $\begin{array}{l}\text { Automotive repair and maintenance; Machinery and equipment repair and maintenance; Funeral homes, cemeteries and } \\
\text { crematories. }\end{array}$ \\
\hline 92 & Public Administration & All in Public Administration. \\
\hline
\end{tabular}




\section{A.5 BLS: Employment Rates Over Time}

Figure A5.1 graphs the seasonally adjusted series for non-farm employment in the US starting May 2000 up until May 2020. The employment data was provided by the Bureau of Labor Statistics. The shaded areas indicate the recessions that we consider in the paper: the 2001 recession, the Great Recession, and the current economic recession arising due to the epidemic.

Figure A5.1: BLS Employment Series (Seasonally Adjusted)

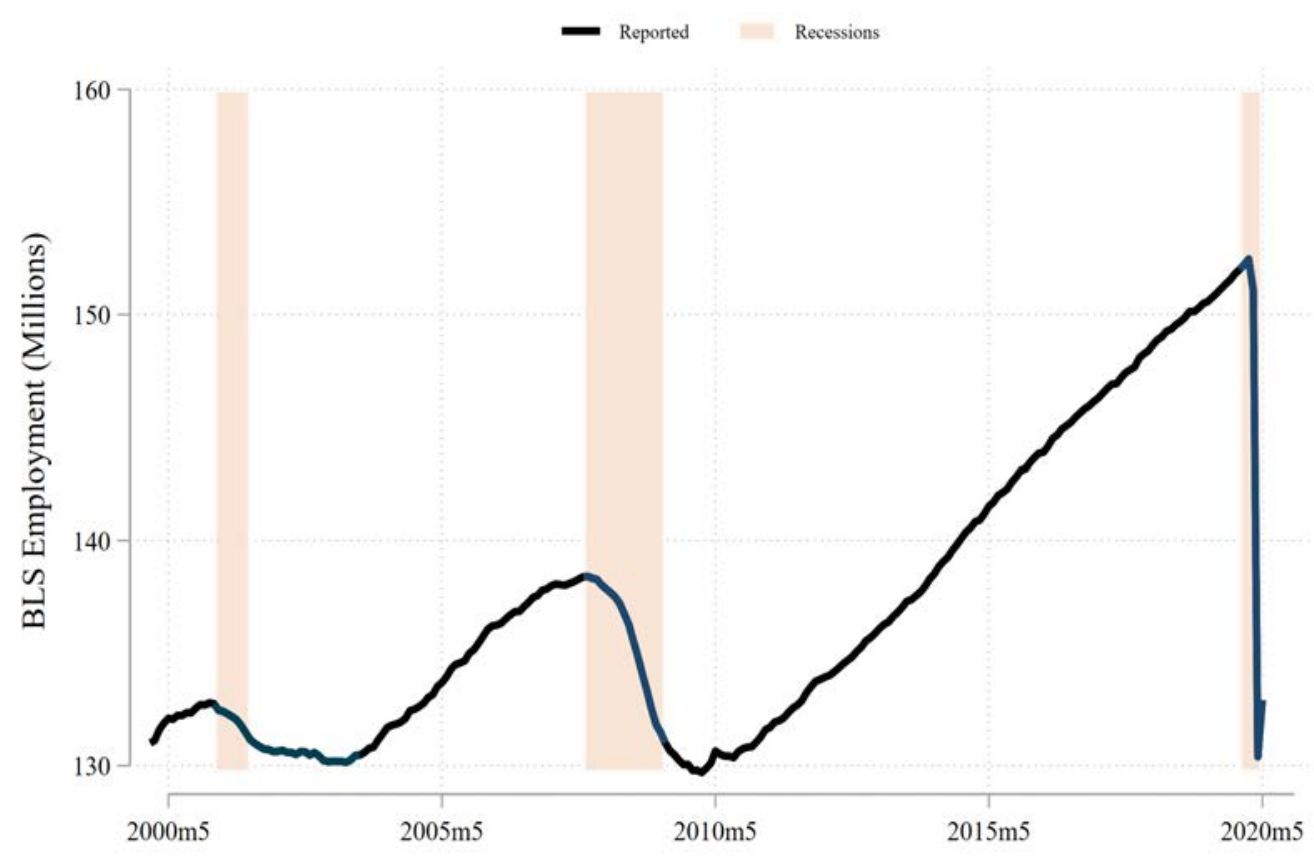

Note: The figure presents the seasonally adjusted series for all employees in non-farm jobs (millions) between January 2000 and May 2020. The shaded areas represent the 2001 Recession (March 2001 to November 2001), the Great Recession (December 2007 to June 2009), and the COVID-19 Recession. The figure implies that jobs lost during April and May 2020 exceed jobs lost in either of the two previous recessions. 


\section{A.6 Teleworkable Index by Socio-Demographic Subgroups}

Figure A6.1 reports the average teleworkable index for the occupations held by all workers in each specific subgroup considered. The figure reports the same statistic as Figure 3, but this time for the teleworkable index built by Dingel and Neiman (2020). Figure A6.1 shows that subgroups who score high (low) in the teleworkable index of their occupations also score high (low) in remote work (Figure 3).

Figure A6.1: Teleworkable Index by Demographic Group - February 2020

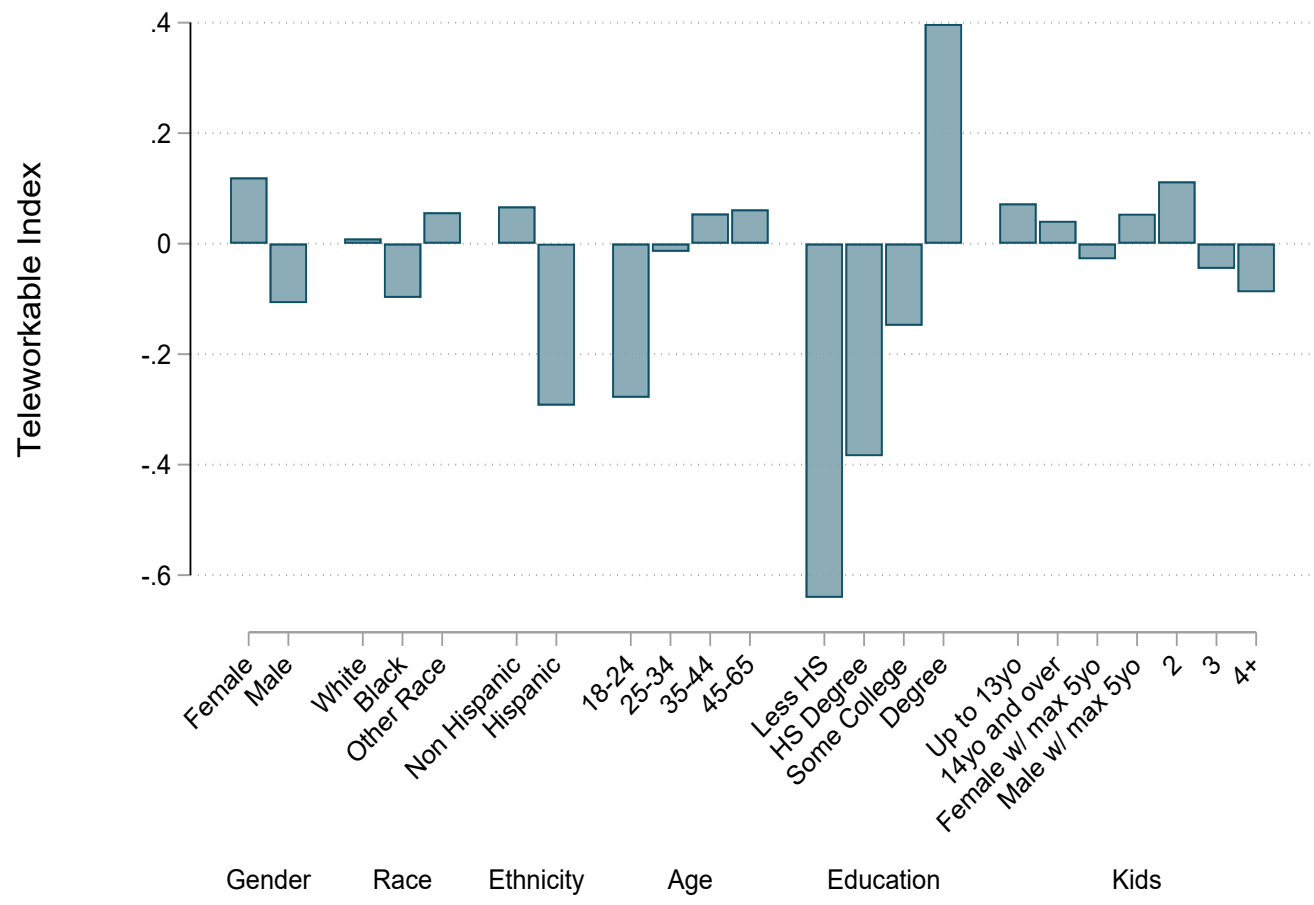

Note: Sample consists of CPS February 2020 respondents age 18-65 years in the labor force. Observations with missing value for any of the covariates that we include in our most specified regression model for the month in consideration have been dropped. This allows to uniform the sample across our entire analysis. The teleworkable index is from Dingel and Neiman (2020). We compute the average of occupations' teleworkable index by subgroup. Negative numbers indicate lack of that characteristic in the jobs of that group. 


\section{A.7 Association of Job Attributes and Employment Outcomes Over Time}

Figures A7.1 and A7.2 report the coefficients from the regression shown on Columns (3) in Tables 1 and 2 for recent unemployment and absent rates, respectively. We show how the magnitude and confidence intervals of each of the coefficients evolve over time, specifically for the months of March, April and May 2019 and 2020. The horizontal dashed red line signals zero. The Figure is effective in showing how the association between the job attributes as well as other covariates and the employment outcomes (i.e. recent unemployment and absence rates) changes over time.

Figure A7.1: Coefficients for Cross-Sectional Models Mar-May 2019 and 2020: Recent Unemployment
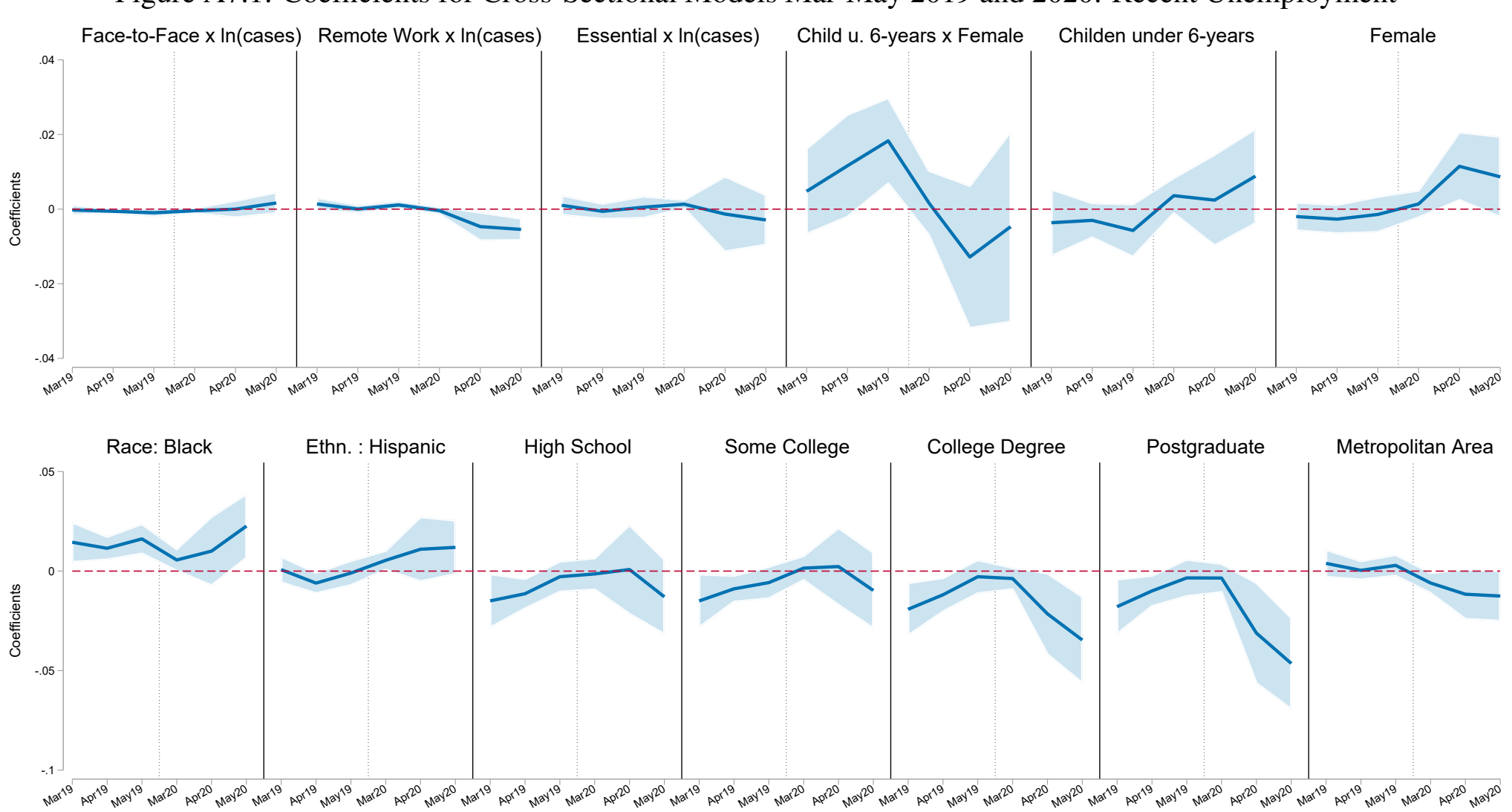

Note: Coefficients for Equation 1 using March, April and May 2019 \& 2020 CPS Data for individuals in the labor force and with recent unemployment as the dependent variable. Results from the specification with occupation and industries fixed effects - Columns (3) in Table 1. Coefficients for Age and its squared are excluded as they move on a different range. Confidence intervals are at the $95 \%$ level. 
Figure A7.2: Coefficients for Cross-Sectional Models Mar-May 2019 and 2020: Absent from Work

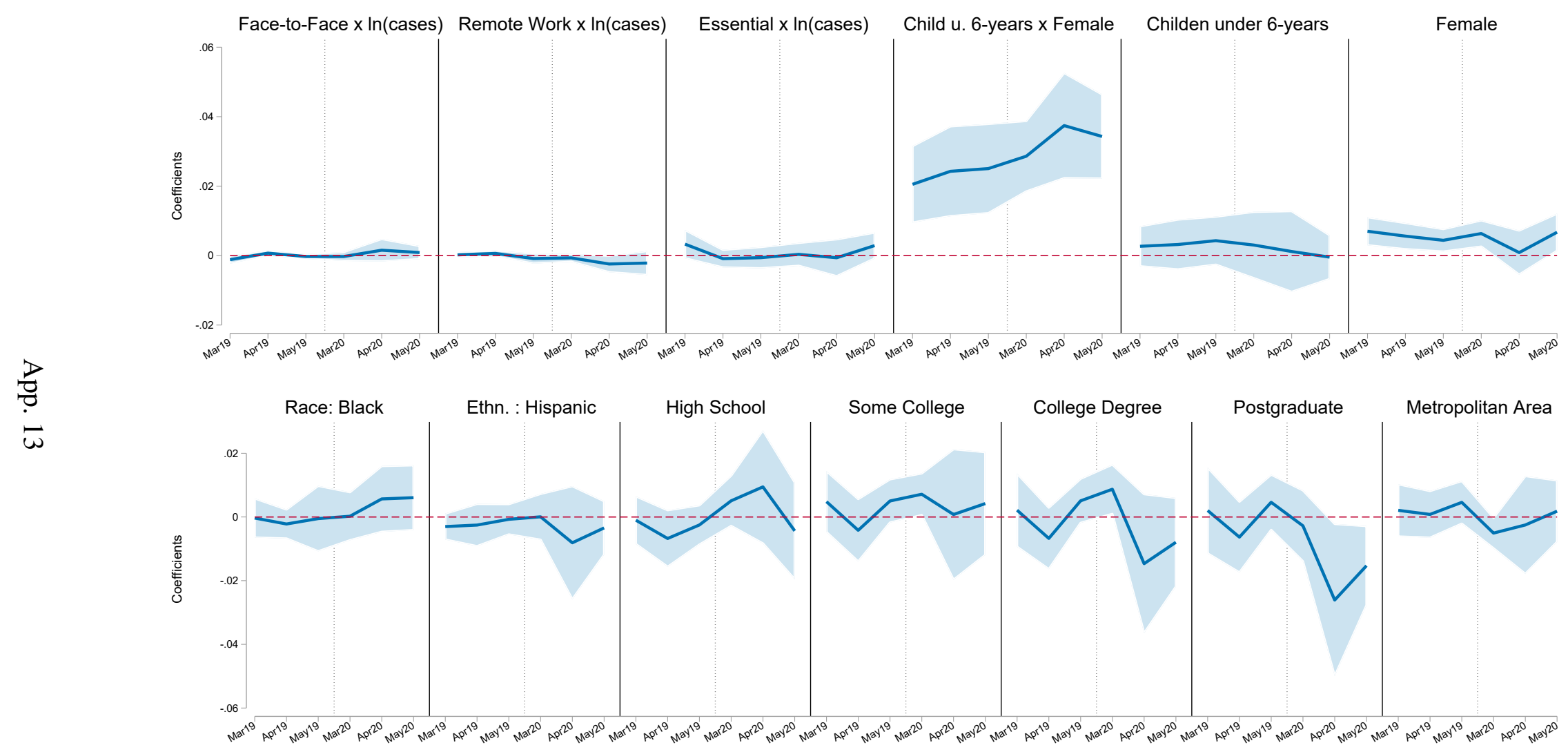

Note: Coefficients for Equation 1 using March, April and May 2019 \& 2020 CPS Data for individuals on the labor force and with recent unemployment as the dependent variable. Results from the specification with occupation and industries fixed effects - Columns (3) in Table 1. Coefficients for Age and its squared are excluded as they move on a different range. Confidence intervals are at the $95 \%$ level. 


\section{A.8 Regressions: the Role of COVID-19 Mortality Risk}

We explore disparities in employment outcomes from epidemiological conditions, beyond COVID-19 cases, including an individual risk factor variable. We constructed a COVID-19 mortality risk index by age and gender using data on case-mortality rates released by CDC China and based on deaths in Mainland China as of February 11, 2020 (Chinese Center for Disease Control and Prevention 2020), which were the best data available at the time. While measures of mortality across demographic groups exist now for the U.S. (Blackburn et al. 2020), the age gradient and gender differences remain, and this information was not available when the main analysis for this paper was carried out.

Our goal with this analysis is to proxy for people's COVID-19 mortality expectations as of the second week of April and of May. We applied the case-fatality rates to the U.S. workers in our sample by transforming the relative mortality rates by age and gender. ${ }^{14}$

The results are presented in Table A8.1 for recent unemployment and in Table A8.2 for absent from work. The coefficient on mortality risk is significant for the recent unemployment rate, and implies a reduction of 1.3 percentage points or $10 \%$ of the employment rate during April, and 0.9 percentage points during May or a $8 \%$ lower rate. The interaction with the job characteristic remote work is the only significant interaction suggesting that the reduction from the mortality risk is lower for workers at remote work occupations. In contrast, when looking at Table A8.2, the mortality risk does not appear to be a factor in temporary absences during April nor May.

\footnotetext{
${ }^{14}$ We use Bayes' theorem to infer mortality rates by age and gender from Chinese Center for Disease Control and Prevention (2020). Specifically, we calculated:

$$
\operatorname{Pr}(\text { Death } \mid \text { Gender }, \text { Age })=\frac{\operatorname{Pr}(\text { Age } \mid \text { Death }) \cdot \operatorname{Pr}(\text { Gender } \mid \text { Death }) \cdot \operatorname{Pr}(\text { Death })}{\operatorname{Pr}(\text { Gender }) \cdot \operatorname{Pr}(\text { Age })}
$$

Where: Gender $=\{$ Female, Male $\}$ and Age $=\{20-29, \ldots, 70-79,80+\}$. We normalize the variable to have mean of one and standard deviation of zero on the entire CPS sample.
} 
Table A8.1: Cross-Sectional Models: Recent Unemployment \& Mortality Risk Index

\begin{tabular}{|c|c|c|c|c|c|c|c|c|c|c|}
\hline \multicolumn{11}{|c|}{ Dependent $=$ Recently Unemployed } \\
\hline & \multicolumn{5}{|c|}{ April - Mean $=0.126$} & \multicolumn{5}{|c|}{ May - Mean $=0.112$} \\
\hline & (1) & (2) & (3) & (4) & (5) & (1) & $(2)$ & (3) & (4) & (5) \\
\hline Face-to-Face & $\begin{array}{c}0.016^{* * *} \\
(0.006)\end{array}$ & $\begin{array}{c}0.016^{* * *} \\
(0.006)\end{array}$ & $\begin{array}{c}0.016^{* * *} \\
(0.006)\end{array}$ & $\begin{array}{c}0.017 \\
(0.011)\end{array}$ & & $\begin{array}{c}0.016^{* * *} \\
(0.005)\end{array}$ & $\begin{array}{c}0.016^{* * *} \\
(0.005)\end{array}$ & $\begin{array}{c}0.016^{* * *} \\
(0.005)\end{array}$ & $\begin{array}{l}-0.003 \\
(0.015)\end{array}$ & \\
\hline Remote Work & $\begin{array}{c}-0.056^{* * *} \\
(0.009)\end{array}$ & $\begin{array}{c}-0.056^{* * *} \\
(0.009)\end{array}$ & $\begin{array}{c}-0.056^{* * *} \\
(0.009)\end{array}$ & $\begin{array}{l}-0.005 \\
(0.021)\end{array}$ & & $\begin{array}{c}-0.045^{* * *} \\
(0.008)\end{array}$ & $\begin{array}{c}-0.045^{* * *} \\
(0.008)\end{array}$ & $\begin{array}{c}-0.045^{* * *} \\
(0.008)\end{array}$ & $\begin{array}{c}0.020 \\
(0.017)\end{array}$ & \\
\hline Essential & $\begin{array}{c}-0.089^{* * *} \\
(0.014)\end{array}$ & $\begin{array}{c}-0.089^{* * *} \\
(0.014)\end{array}$ & $\begin{array}{c}-0.088^{* * *} \\
(0.013)\end{array}$ & $\begin{array}{c}-0.078^{*} \\
(0.045)\end{array}$ & & $\begin{array}{c}-0.073^{* * *} \\
(0.011)\end{array}$ & $\begin{array}{c}-0.073^{* * *} \\
(0.011)\end{array}$ & $\begin{array}{c}-0.072^{* * *} \\
(0.011)\end{array}$ & $\begin{array}{c}-0.056^{*} \\
(0.029)\end{array}$ & \\
\hline Mortality Risk Index & & $\begin{array}{c}-0.012^{* * *} \\
(0.004)\end{array}$ & $\begin{array}{c}-0.016^{* *} \\
(0.007)\end{array}$ & $\begin{array}{c}-0.016^{* *} \\
(0.007)\end{array}$ & $\begin{array}{c}-0.013^{* *} \\
(0.006)\end{array}$ & & $\begin{array}{l}-0.005 \\
(0.004)\end{array}$ & $\begin{array}{c}-0.012^{* *} \\
(0.005)\end{array}$ & $\begin{array}{c}-0.012^{* *} \\
(0.005)\end{array}$ & $\begin{array}{c}-0.009^{* *} \\
(0.003)\end{array}$ \\
\hline Risk x Face-to-Face & & & $\begin{array}{c}0.000 \\
(0.003)\end{array}$ & $\begin{array}{c}0.000 \\
(0.003)\end{array}$ & $\begin{array}{l}-0.001 \\
(0.003)\end{array}$ & & & $\begin{array}{c}0.001 \\
(0.002)\end{array}$ & $\begin{array}{c}0.001 \\
(0.002)\end{array}$ & $\begin{array}{c}0.001 \\
(0.002)\end{array}$ \\
\hline Risk x Remote Work & & & $\begin{array}{c}0.010^{* * *} \\
(0.003)\end{array}$ & $\begin{array}{c}0.010^{* * *} \\
(0.003)\end{array}$ & $\begin{array}{c}0.004^{* *} \\
(0.002)\end{array}$ & & & $\begin{array}{c}0.005^{* * *} \\
(0.002)\end{array}$ & $\begin{array}{c}0.005^{* * *} \\
(0.002)\end{array}$ & $\begin{array}{c}0.001 \\
(0.002)\end{array}$ \\
\hline Risk $\mathrm{x}$ Essential & & & $\begin{array}{c}0.007 \\
(0.006)\end{array}$ & $\begin{array}{c}0.007 \\
(0.006)\end{array}$ & $\begin{array}{c}0.005 \\
(0.005)\end{array}$ & & & $\begin{array}{c}0.010^{* *} \\
(0.005)\end{array}$ & $\begin{array}{c}0.010^{* *} \\
(0.005)\end{array}$ & $\begin{array}{c}0.009^{* *} \\
(0.004)\end{array}$ \\
\hline $\operatorname{Ln}$ (cases) $\times$ Face-to-Face & & & & $\begin{array}{l}-0.000 \\
(0.001)\end{array}$ & $\begin{array}{l}-0.000 \\
(0.001)\end{array}$ & & & & $\begin{array}{c}0.002 \\
(0.002)\end{array}$ & $\begin{array}{c}0.002 \\
(0.001)\end{array}$ \\
\hline $\operatorname{Ln}$ (cases) $x$ Remote & & & & $\begin{array}{c}-0.005^{* * *} \\
(0.002)\end{array}$ & $\begin{array}{c}-0.005^{* *} \\
(0.002)\end{array}$ & & & & $\begin{array}{c}-0.006^{* * *} \\
(0.002)\end{array}$ & $\begin{array}{c}-0.005^{* * *} \\
(0.001)\end{array}$ \\
\hline Ln(cases) $x$ Essential & & & & $\begin{array}{l}-0.001 \\
(0.005)\end{array}$ & $\begin{array}{l}-0.001 \\
(0.005)\end{array}$ & & & & $\begin{array}{l}-0.002 \\
(0.003)\end{array}$ & $\begin{array}{l}-0.003 \\
(0.003)\end{array}$ \\
\hline Fem x Child-U6 & $\begin{array}{l}-0.003 \\
(0.010)\end{array}$ & $\begin{array}{l}-0.000 \\
(0.010)\end{array}$ & $\begin{array}{c}0.001 \\
(0.010)\end{array}$ & $\begin{array}{c}0.001 \\
(0.011)\end{array}$ & $\begin{array}{l}-0.010 \\
(0.010)\end{array}$ & $\begin{array}{c}0.001 \\
(0.015)\end{array}$ & $\begin{array}{c}0.002 \\
(0.015)\end{array}$ & $\begin{array}{c}0.003 \\
(0.015)\end{array}$ & $\begin{array}{c}0.002 \\
(0.016)\end{array}$ & $\begin{array}{l}-0.004 \\
(0.013)\end{array}$ \\
\hline Child under 6 & $\begin{array}{l}-0.009 \\
(0.006)\end{array}$ & $\begin{array}{l}-0.009 \\
(0.006)\end{array}$ & $\begin{array}{l}-0.009 \\
(0.006)\end{array}$ & $\begin{array}{l}-0.009 \\
(0.007)\end{array}$ & $\begin{array}{c}0.002 \\
(0.006)\end{array}$ & $\begin{array}{c}0.000 \\
(0.008)\end{array}$ & $\begin{array}{c}0.000 \\
(0.008)\end{array}$ & $\begin{array}{c}0.000 \\
(0.008)\end{array}$ & $\begin{array}{c}0.000 \\
(0.008)\end{array}$ & $\begin{array}{c}0.009 \\
(0.007)\end{array}$ \\
\hline Female & $\begin{array}{c}0.035^{* * *} \\
(0.008)\end{array}$ & $\begin{array}{c}0.030^{* * *} \\
(0.008)\end{array}$ & $\begin{array}{c}0.031^{* * *} \\
(0.008)\end{array}$ & $\begin{array}{c}0.030^{* * *} \\
(0.008)\end{array}$ & $\begin{array}{l}0.008^{*} \\
(0.005)\end{array}$ & $\begin{array}{c}0.030^{* * *} \\
(0.008)\end{array}$ & $\begin{array}{c}0.028^{* * *} \\
(0.008)\end{array}$ & $\begin{array}{c}0.029^{* * *} \\
(0.008)\end{array}$ & $\begin{array}{c}0.028^{* * *} \\
(0.008)\end{array}$ & $\begin{array}{c}0.008 \\
(0.006)\end{array}$ \\
\hline Black & $\begin{array}{c}0.001 \\
(0.009)\end{array}$ & $\begin{array}{c}0.001 \\
(0.009)\end{array}$ & $\begin{array}{c}0.001 \\
(0.009)\end{array}$ & $\begin{array}{c}0.001 \\
(0.009)\end{array}$ & $\begin{array}{l}0.010 \\
(0.009)\end{array}$ & $\begin{array}{l}0.018^{*} \\
(0.009)\end{array}$ & $\begin{array}{l}0.018^{*} \\
(0.009)\end{array}$ & $\begin{array}{l}0.018^{*} \\
(0.009)\end{array}$ & $\begin{array}{l}0.018^{*} \\
(0.009)\end{array}$ & $\begin{array}{c}0.023^{* * *} \\
(0.008)\end{array}$ \\
\hline Hispanic & $\begin{array}{c}0.012 \\
(0.008)\end{array}$ & $\begin{array}{c}0.012 \\
(0.008)\end{array}$ & $\begin{array}{c}0.012 \\
(0.008)\end{array}$ & $\begin{array}{c}0.012 \\
(0.008)\end{array}$ & $\begin{array}{c}0.011 \\
(0.008)\end{array}$ & $\begin{array}{l}0.015^{*} \\
(0.008)\end{array}$ & $\begin{array}{l}0.015^{*} \\
(0.008)\end{array}$ & $\begin{array}{l}0.015^{*} \\
(0.008)\end{array}$ & $\begin{array}{c}0.014 \\
(0.009)\end{array}$ & $\begin{array}{l}0.012^{*} \\
(0.007)\end{array}$ \\
\hline Age & $\begin{array}{c}-1.185^{* * *} \\
(0.167)\end{array}$ & $\begin{array}{c}-1.409^{* * *} \\
(0.206)\end{array}$ & $\begin{array}{c}-1.344^{* * *} \\
(0.200)\end{array}$ & $\begin{array}{c}-1.351^{* * *} \\
(0.199)\end{array}$ & $\begin{array}{c}-0.925^{* * *} \\
(0.111)\end{array}$ & $\begin{array}{c}-1.091^{* * *} \\
(0.185)\end{array}$ & $\begin{array}{c}-1.188^{* * *} \\
(0.235)\end{array}$ & $\begin{array}{c}-1.162^{* * *} \\
(0.231)\end{array}$ & $\begin{array}{c}-1.167^{* * *} \\
(0.230)\end{array}$ & $\begin{array}{c}-0.704^{* * *} \\
(0.156)\end{array}$ \\
\hline $\mathrm{Age}^{2}$ & $\begin{array}{c}1.273^{* * *} \\
(0.181)\end{array}$ & $\begin{array}{c}1.619^{* * *} \\
(0.246)\end{array}$ & $\begin{array}{c}1.537^{* * *} \\
(0.239)\end{array}$ & $\begin{array}{c}1.544^{* * *} \\
(0.238)\end{array}$ & $\begin{array}{c}1.091^{* * *} \\
(0.145)\end{array}$ & $\begin{array}{c}1.162^{* * *} \\
(0.206)\end{array}$ & $\begin{array}{c}1.311^{* * *} \\
(0.285)\end{array}$ & $\begin{array}{c}1.280^{* * *} \\
(0.280)\end{array}$ & $\begin{array}{c}1.284^{* * *} \\
(0.280)\end{array}$ & $\begin{array}{c}0.789^{* * *} \\
(0.190)\end{array}$ \\
\hline HS & $\begin{array}{l}-0.003 \\
(0.013)\end{array}$ & $\begin{array}{l}-0.002 \\
(0.013)\end{array}$ & $\begin{array}{l}-0.003 \\
(0.013)\end{array}$ & $\begin{array}{l}-0.003 \\
(0.013)\end{array}$ & $\begin{array}{c}0.001 \\
(0.011)\end{array}$ & $\begin{array}{l}-0.008 \\
(0.012)\end{array}$ & $\begin{array}{l}-0.008 \\
(0.012)\end{array}$ & $\begin{array}{l}-0.008 \\
(0.012)\end{array}$ & $\begin{array}{l}-0.008 \\
(0.012)\end{array}$ & $\begin{array}{l}-0.013 \\
(0.009)\end{array}$ \\
\hline Some College & $\begin{array}{c}0.000 \\
(0.013)\end{array}$ & $\begin{array}{c}0.001 \\
(0.013)\end{array}$ & $\begin{array}{l}-0.000 \\
(0.013)\end{array}$ & $\begin{array}{c}0.000 \\
(0.013)\end{array}$ & $\begin{array}{c}0.002 \\
(0.010)\end{array}$ & $\begin{array}{l}-0.005 \\
(0.012)\end{array}$ & $\begin{array}{l}-0.005 \\
(0.012)\end{array}$ & $\begin{array}{l}-0.005 \\
(0.012)\end{array}$ & $\begin{array}{l}-0.005 \\
(0.012)\end{array}$ & $\begin{array}{l}-0.010 \\
(0.009)\end{array}$ \\
\hline BA Degree & $\begin{array}{c}-0.044^{* * *} \\
(0.014)\end{array}$ & $\begin{array}{c}-0.043^{* * *} \\
(0.014)\end{array}$ & $\begin{array}{c}-0.043^{* * *} \\
(0.014)\end{array}$ & $\begin{array}{c}-0.043^{* * *} \\
(0.014)\end{array}$ & $\begin{array}{c}-0.021^{* *} \\
(0.010)\end{array}$ & $\begin{array}{c}-0.046^{* * *} \\
(0.014)\end{array}$ & $\begin{array}{c}-0.045^{* * *} \\
(0.014)\end{array}$ & $\begin{array}{c}-0.046^{* * *} \\
(0.014)\end{array}$ & $\begin{array}{c}-0.045^{* * *} \\
(0.014)\end{array}$ & $\begin{array}{c}-0.035^{* * *} \\
(0.011)\end{array}$ \\
\hline Postgraduate Degree & $\begin{array}{c}-0.079^{* * *} \\
(0.016)\end{array}$ & $\begin{array}{c}-0.078^{* * *} \\
(0.016)\end{array}$ & $\begin{array}{c}-0.079^{* * *} \\
(0.015)\end{array}$ & $\begin{array}{c}-0.078^{* * *} \\
(0.015)\end{array}$ & $\begin{array}{c}-0.031^{* *} \\
(0.013)\end{array}$ & $\begin{array}{c}-0.079^{* * *} \\
(0.015)\end{array}$ & $\begin{array}{c}-0.079^{* * *} \\
(0.015)\end{array}$ & $\begin{array}{c}-0.079^{* * *} \\
(0.015)\end{array}$ & $\begin{array}{c}-0.078^{* * *} \\
(0.015)\end{array}$ & $\begin{array}{c}-0.046^{* * *} \\
(0.011)\end{array}$ \\
\hline Metropolitan & $\begin{array}{c}-0.030^{* * *} \\
(0.007)\end{array}$ & $\begin{array}{c}-0.030^{* * *} \\
(0.007)\end{array}$ & $\begin{array}{c}-0.030^{* * *} \\
(0.007)\end{array}$ & $\begin{array}{c}-0.029^{* * *} \\
(0.008)\end{array}$ & $\begin{array}{c}-0.012^{*} \\
(0.006)\end{array}$ & $\begin{array}{c}-0.029^{* * *} \\
(0.007)\end{array}$ & $\begin{array}{c}-0.029^{* * *} \\
(0.007)\end{array}$ & $\begin{array}{c}-0.029^{* * *} \\
(0.007)\end{array}$ & $\begin{array}{c}-0.028^{* * *} \\
(0.007)\end{array}$ & $\begin{array}{c}-0.013^{*} \\
(0.006)\end{array}$ \\
\hline Constant & $\begin{array}{c}0.484^{* * *} \\
(0.043)\end{array}$ & $\begin{array}{c}0.513^{* * *} \\
(0.048)\end{array}$ & $\begin{array}{c}0.501^{* * *} \\
(0.047)\end{array}$ & $\begin{array}{c}0.502^{* * *} \\
(0.047)\end{array}$ & $\begin{array}{c}0.331^{* * *} \\
(0.046)\end{array}$ & $\begin{array}{c}0.439^{* * *} \\
(0.045)\end{array}$ & $\begin{array}{c}0.452^{* * *} \\
(0.051)\end{array}$ & $\begin{array}{c}0.446^{* * *} \\
(0.050)\end{array}$ & $\begin{array}{c}0.446^{* * *} \\
(0.050)\end{array}$ & $\begin{array}{c}0.306^{* * *} \\
(0.044)\end{array}$ \\
\hline $\begin{array}{l}\text { State f.e. } \\
\text { Occupation \& Industries f.e. }\end{array}$ & $\mathrm{X}$ & $\mathrm{X}$ & $\mathrm{X}$ & $\mathrm{X}$ & $\begin{array}{l}X \\
X\end{array}$ & $\mathrm{X}$ & $\mathrm{X}$ & $\mathrm{X}$ & $\mathrm{X}$ & $\begin{array}{l}X \\
X\end{array}$ \\
\hline $\begin{array}{l}\text { Observations } \\
R^{2}\end{array}$ & $\begin{array}{c}43754 \\
0.079\end{array}$ & $\begin{array}{c}43754 \\
0.079\end{array}$ & $\begin{array}{c}43754 \\
0.080\end{array}$ & $\begin{array}{c}43754 \\
0.080\end{array}$ & $\begin{array}{c}43754 \\
0.196\end{array}$ & $\begin{array}{c}42432 \\
0.067\end{array}$ & $\begin{array}{c}42432 \\
0.067\end{array}$ & $\begin{array}{c}42432 \\
0.068\end{array}$ & $\begin{array}{c}42432 \\
0.068\end{array}$ & $\begin{array}{c}42432 \\
0.173\end{array}$ \\
\hline
\end{tabular}

Notes: Coefficients for Equation 1 using April 2020 CPS Data for individuals on the labor force and with recent unemployment as dependent variable. Column (1) includes socio-demographic and job tasks' characteristics. Column (2) adds COVID-19 mortality factor (Risk) and state COVID-19 exposure. Column (3) and (4) interacts the risk factor and states' COVID-19 exposure with occupation characteristics. Finally, (5) adds states, occupation and industries fixed effects. Standard errors from multi-way clustering at the state and occupation level in parentheses. Statistical significance level: $* \mathrm{p}<0.1 ; * * \mathrm{p}<0.05 ; * * * \mathrm{p}<0.01$ 
Table A8.2: Cross-Sectional Models: Absent from Work \& Mortality Risk Index

\begin{tabular}{|c|c|c|c|c|c|c|c|c|c|c|}
\hline \multicolumn{11}{|c|}{ Dependent = Employed - Absent from Work } \\
\hline & \multicolumn{5}{|c|}{ April - Mean $=0.071$} & \multicolumn{5}{|c|}{ May - Mean $=0.050$} \\
\hline & (1) & (2) & (3) & (4) & (5) & (1) & $(2)$ & (3) & (4) & (5) \\
\hline Face-to-Face & $\begin{array}{c}0.014^{* * *} \\
(0.004)\end{array}$ & $\begin{array}{c}0.014^{* * *} \\
(0.004)\end{array}$ & $\begin{array}{c}0.014^{* * *} \\
(0.004)\end{array}$ & $\begin{array}{c}0.001 \\
(0.014)\end{array}$ & & $\begin{array}{c}0.009^{* * *} \\
(0.003)\end{array}$ & $\begin{array}{c}0.009^{* * *} \\
(0.003)\end{array}$ & $\begin{array}{c}0.009^{* * *} \\
(0.003)\end{array}$ & $\begin{array}{c}0.002 \\
(0.008)\end{array}$ & \\
\hline Remote Work & $\begin{array}{c}-0.014^{* * *} \\
(0.004)\end{array}$ & $\begin{array}{c}-0.014^{* * *} \\
(0.004)\end{array}$ & $\begin{array}{c}-0.014^{* * *} \\
(0.004)\end{array}$ & $\begin{array}{l}0.017^{*} \\
(0.010)\end{array}$ & & $\begin{array}{c}-0.011^{* * *} \\
(0.003)\end{array}$ & $\begin{array}{c}-0.011^{* * *} \\
(0.003)\end{array}$ & $\begin{array}{c}-0.011^{* * *} \\
(0.003)\end{array}$ & $\begin{array}{c}0.016 \\
(0.020)\end{array}$ & \\
\hline Essential & $\begin{array}{c}-0.034^{* * *} \\
(0.007)\end{array}$ & $\begin{array}{c}-0.034^{* * *} \\
(0.007)\end{array}$ & $\begin{array}{c}-0.034^{* * *} \\
(0.007)\end{array}$ & $\begin{array}{l}-0.034 \\
(0.025)\end{array}$ & & $\begin{array}{c}-0.019^{* * *} \\
(0.006)\end{array}$ & $\begin{array}{c}-0.019^{* * *} \\
(0.006)\end{array}$ & $\begin{array}{c}-0.019^{* * *} \\
(0.006)\end{array}$ & $\begin{array}{c}-0.053^{* * *} \\
(0.016)\end{array}$ & \\
\hline Mortality Risk Index & & $\begin{array}{c}0.003 \\
(0.003)\end{array}$ & $\begin{array}{c}0.003 \\
(0.004)\end{array}$ & $\begin{array}{c}0.003 \\
(0.004)\end{array}$ & $\begin{array}{c}0.006 \\
(0.003)\end{array}$ & & $\begin{array}{c}0.003 \\
(0.003)\end{array}$ & $\begin{array}{c}0.004 \\
(0.004)\end{array}$ & $\begin{array}{c}0.004 \\
(0.004)\end{array}$ & $\begin{array}{c}0.005 \\
(0.004)\end{array}$ \\
\hline Risk x Face-to-Face & & & $\begin{array}{l}-0.000 \\
(0.002)\end{array}$ & $\begin{array}{l}-0.000 \\
(0.002)\end{array}$ & $\begin{array}{l}-0.000 \\
(0.002)\end{array}$ & & & $\begin{array}{c}0.001 \\
(0.001)\end{array}$ & $\begin{array}{c}0.001 \\
(0.001)\end{array}$ & $\begin{array}{c}0.001 \\
(0.001)\end{array}$ \\
\hline Risk x Remote Work & & & $\begin{array}{l}0.003^{*} \\
(0.001)\end{array}$ & $\begin{array}{l}0.003^{*} \\
(0.002)\end{array}$ & $\begin{array}{l}0.001 \\
(0.001)\end{array}$ & & & $\begin{array}{c}0.001 \\
(0.001)\end{array}$ & $\begin{array}{c}0.001 \\
(0.001)\end{array}$ & $\begin{array}{l}-0.000 \\
(0.001)\end{array}$ \\
\hline Risk x Essential & & & $\begin{array}{l}-0.000 \\
(0.002)\end{array}$ & $\begin{array}{l}-0.000 \\
(0.002)\end{array}$ & $\begin{array}{l}-0.003^{*} \\
(0.002)\end{array}$ & & & $\begin{array}{l}-0.001 \\
(0.003)\end{array}$ & $\begin{array}{l}-0.001 \\
(0.003)\end{array}$ & $\begin{array}{l}-0.003 \\
(0.003)\end{array}$ \\
\hline $\operatorname{Ln}$ (cases) x Face-to-Face & & & & $\begin{array}{c}0.001 \\
(0.002)\end{array}$ & $\begin{array}{c}0.002 \\
(0.002)\end{array}$ & & & & $\begin{array}{c}0.001 \\
(0.001)\end{array}$ & $\begin{array}{c}0.001 \\
(0.001)\end{array}$ \\
\hline Ln(cases) x Remote & & & & $\begin{array}{c}-0.003^{* * *} \\
(0.001)\end{array}$ & $\begin{array}{c}-0.002^{* *} \\
(0.001)\end{array}$ & & & & $\begin{array}{l}-0.003 \\
(0.002)\end{array}$ & $\begin{array}{l}-0.002 \\
(0.002)\end{array}$ \\
\hline Ln(cases) $x$ Essential & & & & $\begin{array}{c}0.000 \\
(0.003)\end{array}$ & $\begin{array}{c}-0.001 \\
(0.003)\end{array}$ & & & & $\begin{array}{l}0.003^{*} \\
(0.002)\end{array}$ & $\begin{array}{c}0.003 \\
(0.002)\end{array}$ \\
\hline Fem x Child-U6 & $\begin{array}{c}0.039^{* * *} \\
(0.008)\end{array}$ & $\begin{array}{c}0.038^{* * *} \\
(0.008)\end{array}$ & $\begin{array}{c}0.038^{* * *} \\
(0.008)\end{array}$ & $\begin{array}{c}0.039^{* * *} \\
(0.008)\end{array}$ & $\begin{array}{c}0.037^{* * *} \\
(0.008)\end{array}$ & $\begin{array}{c}0.035^{* * *} \\
(0.005)\end{array}$ & $\begin{array}{c}0.034^{* * *} \\
(0.005)\end{array}$ & $\begin{array}{c}0.034^{* * *} \\
(0.005)\end{array}$ & $\begin{array}{c}0.034^{* * *} \\
(0.005)\end{array}$ & $\begin{array}{c}0.034^{* * *} \\
(0.006)\end{array}$ \\
\hline Child under 6 & $\begin{array}{c}0.000 \\
(0.006)\end{array}$ & $\begin{array}{c}0.000 \\
(0.006)\end{array}$ & $\begin{array}{c}0.000 \\
(0.006)\end{array}$ & $\begin{array}{l}-0.000 \\
(0.006)\end{array}$ & $\begin{array}{c}0.001 \\
(0.006)\end{array}$ & $\begin{array}{l}-0.001 \\
(0.003)\end{array}$ & $\begin{array}{l}-0.001 \\
(0.003)\end{array}$ & $\begin{array}{l}-0.001 \\
(0.003)\end{array}$ & $\begin{array}{l}-0.001 \\
(0.003)\end{array}$ & $\begin{array}{l}-0.001 \\
(0.003)\end{array}$ \\
\hline Female & $\begin{array}{c}0.009^{* *} \\
(0.004)\end{array}$ & $\begin{array}{c}0.010^{* *} \\
(0.004)\end{array}$ & $\begin{array}{c}0.010^{* *} \\
(0.004)\end{array}$ & $\begin{array}{c}0.010^{* *} \\
(0.004)\end{array}$ & $\begin{array}{c}0.002 \\
(0.004)\end{array}$ & $\begin{array}{c}0.010^{* * *} \\
(0.003)\end{array}$ & $\begin{array}{c}0.012^{* * *} \\
(0.003)\end{array}$ & $\begin{array}{c}0.012^{* * *} \\
(0.003)\end{array}$ & $\begin{array}{c}0.012^{* * *} \\
(0.004)\end{array}$ & $\begin{array}{l}0.008^{* *} \\
(0.003)\end{array}$ \\
\hline Black & $\begin{array}{l}0.004 \\
(0.005)\end{array}$ & $\begin{array}{c}0.004 \\
(0.005)\end{array}$ & $\begin{array}{c}0.004 \\
(0.005)\end{array}$ & $\begin{array}{c}0.004 \\
(0.006)\end{array}$ & $\begin{array}{c}0.006 \\
(0.005)\end{array}$ & $\begin{array}{c}0.004 \\
(0.005)\end{array}$ & $\begin{array}{c}0.004 \\
(0.005)\end{array}$ & $\begin{array}{c}0.004 \\
(0.005)\end{array}$ & $\begin{array}{c}0.004 \\
(0.005)\end{array}$ & $\begin{array}{c}0.006 \\
(0.005)\end{array}$ \\
\hline Hispanic & $\begin{array}{l}-0.007 \\
(0.010)\end{array}$ & $\begin{array}{l}-0.007 \\
(0.010)\end{array}$ & $\begin{array}{l}-0.007 \\
(0.010)\end{array}$ & $\begin{array}{l}-0.007 \\
(0.010)\end{array}$ & $\begin{array}{l}-0.008 \\
(0.009)\end{array}$ & $\begin{array}{c}-0.004 \\
(0.005)\end{array}$ & $\begin{array}{l}-0.004 \\
(0.005)\end{array}$ & $\begin{array}{l}-0.004 \\
(0.005)\end{array}$ & $\begin{array}{l}-0.004 \\
(0.005)\end{array}$ & $\begin{array}{l}-0.003 \\
(0.004)\end{array}$ \\
\hline Age & $\begin{array}{l}0.025 \\
(0.092)\end{array}$ & $\begin{array}{c}0.078 \\
(0.115)\end{array}$ & $\begin{array}{c}0.098 \\
(0.116)\end{array}$ & $\begin{array}{c}0.094 \\
(0.116)\end{array}$ & $\begin{array}{c}0.110 \\
(0.108)\end{array}$ & $\begin{array}{c}-0.012 \\
(0.074)\end{array}$ & $\begin{array}{c}0.044 \\
(0.104)\end{array}$ & $\begin{array}{c}0.051 \\
(0.104)\end{array}$ & $\begin{array}{c}0.049 \\
(0.104)\end{array}$ & $\begin{array}{l}-0.010 \\
(0.091)\end{array}$ \\
\hline $\mathrm{Age}^{2}$ & $\begin{array}{c}0.039 \\
(0.107)\end{array}$ & $\begin{array}{l}-0.043 \\
(0.151)\end{array}$ & $\begin{array}{l}-0.069 \\
(0.152)\end{array}$ & $\begin{array}{l}-0.065 \\
(0.152)\end{array}$ & $\begin{array}{l}-0.079 \\
(0.147)\end{array}$ & $\begin{array}{c}0.070 \\
(0.078)\end{array}$ & $\begin{array}{l}-0.017 \\
(0.131)\end{array}$ & $\begin{array}{l}-0.026 \\
(0.132)\end{array}$ & $\begin{array}{l}-0.026 \\
(0.133)\end{array}$ & $\begin{array}{c}0.052 \\
(0.115)\end{array}$ \\
\hline HS & $\begin{array}{c}0.005 \\
(0.008)\end{array}$ & $\begin{array}{c}0.004 \\
(0.008)\end{array}$ & $\begin{array}{c}0.004 \\
(0.008)\end{array}$ & $\begin{array}{c}0.004 \\
(0.008)\end{array}$ & $\begin{array}{c}0.009 \\
(0.009)\end{array}$ & $\begin{array}{l}-0.005 \\
(0.008)\end{array}$ & $\begin{array}{l}-0.005 \\
(0.008)\end{array}$ & $\begin{array}{l}-0.005 \\
(0.008)\end{array}$ & $\begin{array}{l}-0.005 \\
(0.008)\end{array}$ & $\begin{array}{l}-0.004 \\
(0.008)\end{array}$ \\
\hline Some College & $\begin{array}{l}-0.006 \\
(0.010)\end{array}$ & $\begin{array}{l}-0.006 \\
(0.010)\end{array}$ & $\begin{array}{c}-0.006 \\
(0.010)\end{array}$ & $\begin{array}{c}-0.006 \\
(0.010)\end{array}$ & $\begin{array}{c}0.001 \\
(0.010)\end{array}$ & $\begin{array}{c}0.004 \\
(0.008)\end{array}$ & $\begin{array}{c}0.004 \\
(0.008)\end{array}$ & $\begin{array}{c}0.004 \\
(0.008)\end{array}$ & $\begin{array}{c}0.004 \\
(0.009)\end{array}$ & $\begin{array}{c}0.004 \\
(0.008)\end{array}$ \\
\hline BA Degree & $\begin{array}{c}-0.030^{* * *} \\
(0.010)\end{array}$ & $\begin{array}{c}-0.030^{* * *} \\
(0.010)\end{array}$ & $\begin{array}{c}-0.030^{* * *} \\
(0.010)\end{array}$ & $\begin{array}{c}-0.030^{* * *} \\
(0.010)\end{array}$ & $\begin{array}{l}-0.015 \\
(0.011)\end{array}$ & $\begin{array}{l}-0.013 \\
(0.008)\end{array}$ & $\begin{array}{c}-0.013 \\
(0.008)\end{array}$ & $\begin{array}{l}-0.013 \\
(0.008)\end{array}$ & $\begin{array}{l}-0.013 \\
(0.009)\end{array}$ & $\begin{array}{l}-0.008 \\
(0.007)\end{array}$ \\
\hline Postgraduate Degree & $\begin{array}{c}-0.050^{* * *} \\
(0.011)\end{array}$ & $\begin{array}{c}-0.050^{* * *} \\
(0.011)\end{array}$ & $\begin{array}{c}-0.051^{* * *} \\
(0.011)\end{array}$ & $\begin{array}{c}-0.050^{* * *} \\
(0.011)\end{array}$ & $\begin{array}{c}-0.026^{* *} \\
(0.012)\end{array}$ & $\begin{array}{c}-0.029^{* * *} \\
(0.009)\end{array}$ & $\begin{array}{c}-0.029^{* * *} \\
(0.009)\end{array}$ & $\begin{array}{c}-0.029^{* * *} \\
(0.009)\end{array}$ & $\begin{array}{c}-0.029^{* * *} \\
(0.009)\end{array}$ & $\begin{array}{c}-0.015^{* *} \\
(0.006)\end{array}$ \\
\hline Metropolitan & $\begin{array}{c}-0.009 \\
(0.008)\end{array}$ & $\begin{array}{l}-0.009 \\
(0.008)\end{array}$ & $\begin{array}{l}-0.009 \\
(0.008)\end{array}$ & $\begin{array}{c}-0.008 \\
(0.008)\end{array}$ & $\begin{array}{c}-0.003 \\
(0.008)\end{array}$ & $\begin{array}{c}-0.003 \\
(0.005)\end{array}$ & $\begin{array}{c}-0.003 \\
(0.005)\end{array}$ & $\begin{array}{c}-0.003 \\
(0.005)\end{array}$ & $\begin{array}{c}-0.003 \\
(0.005)\end{array}$ & $\begin{array}{c}0.002 \\
(0.005)\end{array}$ \\
\hline Constant & $\begin{array}{c}0.098^{* * *} \\
(0.020)\end{array}$ & $\begin{array}{c}0.091^{* * *} \\
(0.019)\end{array}$ & $\begin{array}{c}0.088^{* * *} \\
(0.020)\end{array}$ & $\begin{array}{c}0.088^{* * *} \\
(0.020)\end{array}$ & $\begin{array}{l}0.052^{*} \\
(0.030)\end{array}$ & $\begin{array}{c}0.061^{* * *} \\
(0.015)\end{array}$ & $\begin{array}{c}0.054^{* * *} \\
(0.019)\end{array}$ & $\begin{array}{c}0.053^{* * *} \\
(0.018)\end{array}$ & $\begin{array}{c}0.053^{* * *} \\
(0.018)\end{array}$ & $\begin{array}{c}0.022 \\
(0.019) \\
\end{array}$ \\
\hline $\begin{array}{l}\text { State f.e. } \\
\text { Occupation \& Industries f.e. }\end{array}$ & $\mathrm{X}$ & $\mathrm{X}$ & $\mathrm{X}$ & $\mathrm{X}$ & $\begin{array}{l}X \\
X\end{array}$ & $\mathrm{X}$ & $\mathrm{X}$ & $\mathrm{X}$ & $\mathrm{X}$ & $\begin{array}{l}X \\
X\end{array}$ \\
\hline $\begin{array}{l}\text { Observations } \\
R^{2}\end{array}$ & $\begin{array}{c}43754 \\
0.023\end{array}$ & $\begin{array}{l}43754 \\
0.023\end{array}$ & $\begin{array}{c}43754 \\
0.023\end{array}$ & $\begin{array}{c}43754 \\
0.023\end{array}$ & $\begin{array}{c}43754 \\
0.074\end{array}$ & $\begin{array}{l}42432 \\
0.016\end{array}$ & $\begin{array}{l}42432 \\
0.016\end{array}$ & $\begin{array}{l}42432 \\
0.016\end{array}$ & $\begin{array}{c}42432 \\
0.016\end{array}$ & $\begin{array}{c}42432 \\
0.062\end{array}$ \\
\hline
\end{tabular}

Notes: Coefficients for Equation 1 using April 2020 CPS Data for individuals on the labor force and with recent unemployment as dependent variable. Column (1) includes socio-demographic and job tasks' characteristics. Column (2) adds COVID-19 mortality factor (Risk) and state COVID-19 exposure. Column (3) and (4) interacts the risk factor and states' COVID-19 exposure with occupation characteristics. Finally, (5) adds states, occupation and industries fixed effects. Standard errors from multi-way clustering at the state and occupation level in parentheses. Statistical significance level: * $\mathrm{p}<0.1 ; * * \mathrm{p}<0.05 ; * * * \mathrm{p}<0.01$ 


\section{A.9 Additional Labor Market Outcome: Combined Not at Work}

Table A9.1 reports the outputs of the regressions we show in Tables A8.1 and A8.2 but this time using as outcome a "Combined no Work" variable. In fact, the outcome explored in Table A9.1 combines recent unemployment and employed but absent from work, which so far have been explored separately.

Table A9.1: Cross-Sectional Models: Combined Not at Work status

\begin{tabular}{|c|c|c|c|c|c|c|}
\hline \multicolumn{7}{|c|}{ Dependent $=$ Combined Recent No Work (Recently Unemployed \& Employed - Absent from Work) } \\
\hline & \multicolumn{3}{|c|}{ April - Mean $=0.197$} & \multicolumn{3}{|c|}{ May - Mean $=0.162$} \\
\hline & (1) & (2) & (3) & (1) & (2) & (3) \\
\hline Face-to-Face & $\begin{array}{c}0.030^{* * *} \\
(0.008)\end{array}$ & $\begin{array}{c}0.018 \\
(0.018)\end{array}$ & & $\begin{array}{c}0.024^{* * *} \\
(0.007)\end{array}$ & $\begin{array}{l}-0.001 \\
(0.017)\end{array}$ & \\
\hline Remote Work & $\begin{array}{c}-0.070^{* * *} \\
(0.011)\end{array}$ & $\begin{array}{c}0.011 \\
(0.020)\end{array}$ & & $\begin{array}{c}-0.056^{* * *} \\
(0.009)\end{array}$ & $\begin{array}{c}0.035 \\
(0.028)\end{array}$ & \\
\hline Essential & $\begin{array}{c}-0.122^{* * *} \\
(0.019)\end{array}$ & $\begin{array}{c}-0.112^{* * *} \\
(0.039)\end{array}$ & & $\begin{array}{c}-0.092^{* * *} \\
(0.015)\end{array}$ & $\begin{array}{c}-0.111^{* * *} \\
(0.029)\end{array}$ & \\
\hline Ln(cases) x Face-to-Face & & $\begin{array}{c}0.001 \\
(0.002)\end{array}$ & $\begin{array}{c}0.002 \\
(0.002)\end{array}$ & & $\begin{array}{c}0.002 \\
(0.002)\end{array}$ & $\begin{array}{c}0.003 \\
(0.002)\end{array}$ \\
\hline Ln(cases) $x$ Remote & & $\begin{array}{c}-0.009^{* * *} \\
(0.002)\end{array}$ & $\begin{array}{c}-0.007^{* * *} \\
(0.002)\end{array}$ & & $\begin{array}{c}-0.009^{* * *} \\
(0.003)\end{array}$ & $\begin{array}{c}-0.008^{* * *} \\
(0.002)\end{array}$ \\
\hline Ln(cases) x Essential & & $\begin{array}{l}-0.001 \\
(0.004)\end{array}$ & $\begin{array}{l}-0.002 \\
(0.005)\end{array}$ & & $\begin{array}{c}0.002 \\
(0.003)\end{array}$ & $\begin{array}{c}-0.000 \\
(0.004)\end{array}$ \\
\hline Fem x Child-U6 & $\begin{array}{c}0.036^{* * *} \\
(0.011)\end{array}$ & $\begin{array}{c}0.036^{* * *} \\
(0.011)\end{array}$ & $\begin{array}{c}0.025^{* *} \\
(0.010)\end{array}$ & $\begin{array}{c}0.036^{* *} \\
(0.015)\end{array}$ & $\begin{array}{c}0.035^{* *} \\
(0.015)\end{array}$ & $\begin{array}{c}0.030^{* *} \\
(0.013)\end{array}$ \\
\hline Child under 6 & $\begin{array}{l}-0.009 \\
(0.008)\end{array}$ & $\begin{array}{l}-0.009 \\
(0.008)\end{array}$ & $\begin{array}{c}0.004 \\
(0.007)\end{array}$ & $\begin{array}{l}-0.001 \\
(0.009)\end{array}$ & $\begin{array}{l}-0.001 \\
(0.009)\end{array}$ & $\begin{array}{c}0.008 \\
(0.008)\end{array}$ \\
\hline Female & $\begin{array}{c}0.043^{* * *} \\
(0.011)\end{array}$ & $\begin{array}{c}0.043^{* * *} \\
(0.011)\end{array}$ & $\begin{array}{l}0.012^{* *} \\
(0.005)\end{array}$ & $\begin{array}{c}0.041^{* * *} \\
(0.010)\end{array}$ & $\begin{array}{c}0.040^{* * *} \\
(0.010)\end{array}$ & $\begin{array}{c}0.015^{* *} \\
(0.006)\end{array}$ \\
\hline Black & $\begin{array}{c}0.005 \\
(0.010)\end{array}$ & $\begin{array}{c}0.005 \\
(0.010)\end{array}$ & $\begin{array}{l}0.016^{*} \\
(0.009)\end{array}$ & $\begin{array}{l}0.022^{* *} \\
(0.010)\end{array}$ & $\begin{array}{c}0.022^{* *} \\
(0.010)\end{array}$ & $\begin{array}{c}0.029^{* * *} \\
(0.008)\end{array}$ \\
\hline Hispanic & $\begin{array}{c}0.006 \\
(0.014)\end{array}$ & $\begin{array}{c}0.004 \\
(0.014)\end{array}$ & $\begin{array}{c}0.003 \\
(0.011)\end{array}$ & $\begin{array}{c}0.012 \\
(0.012)\end{array}$ & $\begin{array}{c}0.010 \\
(0.012)\end{array}$ & $\begin{array}{c}0.008 \\
(0.009)\end{array}$ \\
\hline Age & $\begin{array}{c}-1.160^{* * *} \\
(0.194)\end{array}$ & $\begin{array}{c}-1.172^{* * *} \\
(0.193)\end{array}$ & $\begin{array}{c}-0.737^{* * *} \\
(0.108)\end{array}$ & $\begin{array}{c}-1.103^{* * *} \\
(0.227)\end{array}$ & $\begin{array}{c}-1.113^{* * *} \\
(0.226)\end{array}$ & $\begin{array}{c}-0.713^{* * *} \\
(0.161)\end{array}$ \\
\hline $\mathrm{Age}^{2}$ & $\begin{array}{c}1.312^{* * *} \\
(0.212)\end{array}$ & $\begin{array}{c}1.323^{* * *} \\
(0.211)\end{array}$ & $\begin{array}{c}0.884^{* * *} \\
(0.130)\end{array}$ & $\begin{array}{c}1.232^{* * * *} \\
(0.256)\end{array}$ & $\begin{array}{c}1.241^{* * *} \\
(0.255)\end{array}$ & $\begin{array}{c}0.840^{* * *} \\
(0.182)\end{array}$ \\
\hline HS & $\begin{array}{c}0.002 \\
(0.013)\end{array}$ & $\begin{array}{c}0.002 \\
(0.013)\end{array}$ & $\begin{array}{c}0.010 \\
(0.011)\end{array}$ & $\begin{array}{l}-0.013 \\
(0.013)\end{array}$ & $\begin{array}{l}-0.012 \\
(0.013)\end{array}$ & $\begin{array}{l}-0.017 \\
(0.011)\end{array}$ \\
\hline Some College & $\begin{array}{l}-0.006 \\
(0.015)\end{array}$ & $\begin{array}{l}-0.005 \\
(0.015)\end{array}$ & $\begin{array}{c}0.003 \\
(0.012)\end{array}$ & $\begin{array}{l}-0.001 \\
(0.012)\end{array}$ & $\begin{array}{c}0.000 \\
(0.012)\end{array}$ & $\begin{array}{l}-0.005 \\
(0.011)\end{array}$ \\
\hline BA Degree & $\begin{array}{c}-0.074^{* * *} \\
(0.016)\end{array}$ & $\begin{array}{c}-0.073^{* * *} \\
(0.016)\end{array}$ & $\begin{array}{c}-0.036^{* * *} \\
(0.012)\end{array}$ & $\begin{array}{c}-0.059^{* * *} \\
(0.015)\end{array}$ & $\begin{array}{c}-0.058^{* * *} \\
(0.015)\end{array}$ & $\begin{array}{c}-0.043^{* * *} \\
(0.012)\end{array}$ \\
\hline Postgraduate Degree & $\begin{array}{c}-0.129^{* * *} \\
(0.019)\end{array}$ & $\begin{array}{c}-0.128^{* * *} \\
(0.019)\end{array}$ & $\begin{array}{c}-0.057^{* * *} \\
(0.015)\end{array}$ & $\begin{array}{c}-0.108^{* * *} \\
(0.017)\end{array}$ & $\begin{array}{c}-0.106^{* * *} \\
(0.017)\end{array}$ & $\begin{array}{c}-0.062^{* * *} \\
(0.012)\end{array}$ \\
\hline Metropolitan & $\begin{array}{c}-0.039^{* * *} \\
(0.010)\end{array}$ & $\begin{array}{c}-0.037^{* * *} \\
(0.010)\end{array}$ & $\begin{array}{l}-0.014 \\
(0.009)\end{array}$ & $\begin{array}{c}-0.032^{* * *} \\
(0.008)\end{array}$ & $\begin{array}{c}-0.031^{* * *} \\
(0.008)\end{array}$ & $\begin{array}{l}-0.011 \\
(0.007)\end{array}$ \\
\hline Constant & $\begin{array}{c}0.582^{* * *} \\
(0.050)\end{array}$ & $\begin{array}{c}0.584^{* * *} \\
(0.050)\end{array}$ & $\begin{array}{c}0.374^{* * *} \\
(0.047)\end{array}$ & $\begin{array}{c}0.500^{* * *} \\
(0.051)\end{array}$ & $\begin{array}{c}0.501^{* * *} \\
(0.051)\end{array}$ & $\begin{array}{c}0.328^{* * *} \\
(0.046)\end{array}$ \\
\hline $\begin{array}{l}\text { State f.e. } \\
\text { Occupation \& Industries f.e. }\end{array}$ & $\mathrm{X}$ & $\mathrm{X}$ & $\begin{array}{l}X \\
X\end{array}$ & $\mathrm{X}$ & $\mathrm{X}$ & $\begin{array}{l}X \\
X\end{array}$ \\
\hline $\begin{array}{l}\text { Observations } \\
R^{2}\end{array}$ & $\begin{array}{c}43754 \\
0.094\end{array}$ & $\begin{array}{c}43754 \\
0.095\end{array}$ & $\begin{array}{c}43754 \\
0.232\end{array}$ & $\begin{array}{l}42432 \\
0.077\end{array}$ & $\begin{array}{c}42432 \\
0.078\end{array}$ & $\begin{array}{c}42432 \\
0.191\end{array}$ \\
\hline
\end{tabular}

Notes: Coefficients for Equation 1 using April (left panel) and May (right panel) 2020 CPS Data for individuals on the labor force and, as the dependent variable, a combined definition of not at work status, including recently unemployed and temporary absent from work. Column (1) includes socio-demographic and job tasks' characteristics. Column (2) adds the states' epidemiological conditions as measured by their COVID-19 log exposure, interacted with occupation characteristics. Column (3) adds occupation and industries fixed effects. All models include state fixed effects. Standard errors from multi-way clustering at the state and occupation level in parentheses. Statistical significance level: $* \mathrm{p}<0.1 ; * * \mathrm{p}<0.05 ; * * * \mathrm{p}<0.01$ 


\section{A.10 Regressions: Results using 2019 Data}

For robustness, we run the same regression shown in Tables A8.1 and A8.2 but this time using data from April and May 2019. These estimates are useful in understanding the direction, and mostly the strength, of the relationship between the employment outcomes and our regressors (job and industry characteristics, and socio-demographic variables) in the same way we do for 2020, but in a year where the epidemic did not strike yet. We should consider these estimates as the baseline, and the difference with the 2020 estimates is likely attributed to the effects of the epidemic.

Table A10.1: Cross-Sectional Models: Using data for 2019 - Recent Unemployment

\begin{tabular}{|c|c|c|c|c|c|c|}
\hline \multicolumn{7}{|l|}{ Dependent $=$ Recently Unemployed } \\
\hline & \multicolumn{3}{|c|}{ April - Mean $=0.0141$} & \multicolumn{3}{|c|}{ May - Mean $=0.018$} \\
\hline & (1) & (2) & (3) & (1) & (2) & (3) \\
\hline Face-to-Face & $\begin{array}{l}-0.001 \\
(0.001)\end{array}$ & $\begin{array}{c}0.003 \\
(0.003)\end{array}$ & & $\begin{array}{c}-0.002^{*} \\
(0.001)\end{array}$ & $\begin{array}{c}0.007 \\
(0.005)\end{array}$ & \\
\hline Remote Work & $\begin{array}{c}-0.005^{* * *} \\
(0.001)\end{array}$ & $\begin{array}{l}-0.006 \\
(0.005)\end{array}$ & & $\begin{array}{c}-0.005^{* * *} \\
(0.001)\end{array}$ & $\begin{array}{c}-0.014^{* * *} \\
(0.005)\end{array}$ & \\
\hline Essential & $\begin{array}{l}-0.001 \\
(0.003)\end{array}$ & $\begin{array}{c}0.006 \\
(0.010)\end{array}$ & & $\begin{array}{c}-0.006^{* *} \\
(0.002)\end{array}$ & $\begin{array}{l}-0.013 \\
(0.016)\end{array}$ & \\
\hline Ln(COVID cases) $x$ Face-to-Face & & $\begin{array}{l}-0.000 \\
(0.000)\end{array}$ & $\begin{array}{c}-0.001^{*} \\
(0.000)\end{array}$ & & $\begin{array}{c}-0.001^{*} \\
(0.000)\end{array}$ & $\begin{array}{c}-0.001^{*} \\
(0.001)\end{array}$ \\
\hline Ln(COVID cases) $x$ Remote & & $\begin{array}{c}0.000 \\
(0.001)\end{array}$ & $\begin{array}{c}0.000 \\
(0.001)\end{array}$ & & $\begin{array}{c}0.001^{* *} \\
(0.000)\end{array}$ & $\begin{array}{c}0.001^{* *} \\
(0.001)\end{array}$ \\
\hline Ln(COVID cases $) \times$ Essential & & $\begin{array}{l}-0.001 \\
(0.001)\end{array}$ & $\begin{array}{l}-0.001 \\
(0.001)\end{array}$ & & $\begin{array}{c}0.001 \\
(0.002)\end{array}$ & $\begin{array}{c}0.001 \\
(0.001)\end{array}$ \\
\hline Fem x Child-U6 & $\begin{array}{c}0.011 \\
(0.007)\end{array}$ & $\begin{array}{c}0.011 \\
(0.007)\end{array}$ & $\begin{array}{l}0.012^{*} \\
(0.007)\end{array}$ & $\begin{array}{c}0.018^{* * *} \\
(0.006)\end{array}$ & $\begin{array}{c}0.018^{* * * *} \\
(0.006)\end{array}$ & $\begin{array}{c}0.018^{* * *} \\
(0.006)\end{array}$ \\
\hline Child under 6 & $\begin{array}{l}-0.003 \\
(0.002)\end{array}$ & $\begin{array}{l}-0.003 \\
(0.002)\end{array}$ & $\begin{array}{l}-0.003 \\
(0.002)\end{array}$ & $\begin{array}{c}-0.006^{*} \\
(0.004)\end{array}$ & $\begin{array}{c}-0.007^{*} \\
(0.004)\end{array}$ & $\begin{array}{l}-0.006 \\
(0.004)\end{array}$ \\
\hline Female & $\begin{array}{c}-0.003^{*} \\
(0.002)\end{array}$ & $\begin{array}{l}-0.003 \\
(0.002)\end{array}$ & $\begin{array}{l}-0.003 \\
(0.002)\end{array}$ & $\begin{array}{c}-0.003^{*} \\
(0.002)\end{array}$ & $\begin{array}{l}-0.003 \\
(0.002)\end{array}$ & $\begin{array}{l}-0.001 \\
(0.002)\end{array}$ \\
\hline Black & $\begin{array}{c}0.012^{* * *} \\
(0.003)\end{array}$ & $\begin{array}{c}0.012^{* * *} \\
(0.003)\end{array}$ & $\begin{array}{c}0.011^{* * *} \\
(0.003)\end{array}$ & $\begin{array}{c}0.018^{* * *} \\
(0.004)\end{array}$ & $\begin{array}{c}0.018^{* * *} \\
(0.004)\end{array}$ & $\begin{array}{c}0.016^{* * *} \\
(0.004)\end{array}$ \\
\hline Hispanic & $\begin{array}{c}-0.005^{*} \\
(0.003)\end{array}$ & $\begin{array}{c}-0.005^{*} \\
(0.003)\end{array}$ & $\begin{array}{c}-0.006^{* *} \\
(0.003)\end{array}$ & $\begin{array}{c}0.000 \\
(0.003)\end{array}$ & $\begin{array}{c}0.000 \\
(0.003)\end{array}$ & $\begin{array}{l}-0.001 \\
(0.003)\end{array}$ \\
\hline Age & $\begin{array}{c}-0.209^{* * *} \\
(0.050)\end{array}$ & $\begin{array}{c}-0.209^{* * *} \\
(0.050)\end{array}$ & $\begin{array}{c}-0.174^{* * *} \\
(0.045)\end{array}$ & $\begin{array}{c}-0.354^{* * *} \\
(0.054)\end{array}$ & $\begin{array}{c}-0.353^{* * *} \\
(0.054)\end{array}$ & $\begin{array}{c}-0.303^{* * *} \\
(0.048)\end{array}$ \\
\hline $\mathrm{Age}^{2}$ & $\begin{array}{c}0.203^{* * *} \\
(0.056)\end{array}$ & $\begin{array}{c}0.203^{* * *} \\
(0.056)\end{array}$ & $\begin{array}{c}0.169^{* * *} \\
(0.050)\end{array}$ & $\begin{array}{c}0.367^{* * *} \\
(0.058)\end{array}$ & $\begin{array}{c}0.366^{* * *} \\
(0.058)\end{array}$ & $\begin{array}{l}0.318^{* * *} \\
(0.051)\end{array}$ \\
\hline HS & $\begin{array}{c}-0.015^{* * *} \\
(0.003)\end{array}$ & $\begin{array}{c}-0.015^{* * *} \\
(0.003)\end{array}$ & $\begin{array}{c}-0.011^{* * *} \\
(0.004)\end{array}$ & $\begin{array}{l}-0.003 \\
(0.003)\end{array}$ & $\begin{array}{l}-0.003 \\
(0.003)\end{array}$ & $\begin{array}{l}-0.003 \\
(0.004)\end{array}$ \\
\hline Some College & $\begin{array}{c}-0.013^{* * *} \\
(0.002)\end{array}$ & $\begin{array}{c}-0.013^{* * *} \\
(0.002)\end{array}$ & $\begin{array}{c}-0.009^{* * *} \\
(0.003)\end{array}$ & $\begin{array}{c}-0.008^{* *} \\
(0.004)\end{array}$ & $\begin{array}{c}-0.008^{* *} \\
(0.004)\end{array}$ & $\begin{array}{l}-0.006 \\
(0.004)\end{array}$ \\
\hline BA Degree & $\begin{array}{c}-0.017^{* * *} \\
(0.003)\end{array}$ & $\begin{array}{c}-0.017^{* * *} \\
(0.003)\end{array}$ & $\begin{array}{c}-0.012^{* * *} \\
(0.004)\end{array}$ & $\begin{array}{c}-0.008^{* *} \\
(0.004)\end{array}$ & $\begin{array}{c}-0.008^{* *} \\
(0.004)\end{array}$ & $\begin{array}{l}-0.003 \\
(0.004)\end{array}$ \\
\hline Posgraduate Degree & $\begin{array}{c}-0.018^{* * *} \\
(0.003)\end{array}$ & $\begin{array}{c}-0.018^{* * *} \\
(0.003)\end{array}$ & $\begin{array}{c}-0.010^{* *} \\
(0.004)\end{array}$ & $\begin{array}{c}-0.011^{* * *} \\
(0.003)\end{array}$ & $\begin{array}{c}-0.011^{* * *} \\
(0.004)\end{array}$ & $\begin{array}{l}-0.003 \\
(0.005)\end{array}$ \\
\hline Metropolitan & $\begin{array}{l}-0.000 \\
(0.002)\end{array}$ & $\begin{array}{l}-0.000 \\
(0.002)\end{array}$ & $\begin{array}{c}0.000 \\
(0.002)\end{array}$ & $\begin{array}{c}0.002 \\
(0.003)\end{array}$ & $\begin{array}{c}0.002 \\
(0.003)\end{array}$ & $\begin{array}{c}0.003 \\
(0.003)\end{array}$ \\
\hline Constant & $\begin{array}{l}0.077^{* * * *} \\
(0.010)\end{array}$ & $\begin{array}{l}0.077^{* * *} \\
(0.010)\end{array}$ & $\begin{array}{l}0.068^{* * *} \\
(0.012)\end{array}$ & $\begin{array}{l}0.103^{* * *} \\
(0.014)\end{array}$ & $\begin{array}{c}0.103^{* * *} \\
(0.014)\end{array}$ & $\begin{array}{c}0.078^{* * *} \\
(0.014)\end{array}$ \\
\hline $\begin{array}{l}\text { State f.e. } \\
\text { Occupation \& Industries f.e. }\end{array}$ & $\mathrm{X}$ & $\mathrm{X}$ & $\begin{array}{l}X \\
X\end{array}$ & $\mathrm{X}$ & $\mathrm{X}$ & $\begin{array}{l}X \\
X\end{array}$ \\
\hline $\begin{array}{l}\text { Observations } \\
R^{2}\end{array}$ & $\begin{array}{c}40268 \\
0.011\end{array}$ & $\begin{array}{c}40268 \\
0.011\end{array}$ & $\begin{array}{c}40268 \\
0.041\end{array}$ & $\begin{array}{c}39630 \\
0.012\end{array}$ & $\begin{array}{l}39630 \\
0.013\end{array}$ & $\begin{array}{l}39630 \\
0.043\end{array}$ \\
\hline
\end{tabular}

Notes: Coefficients for Equation 1 using April (left panel) and May (right panel) 2019 CPS Data for individuals on the labor force and with recent unemployment as the dependent variable. Column (1) includes socio-demographic and job tasks' characteristics. Column (2) adds the states' epidemiological conditions as measured by their COVID-19 log exposure during the exact same month in 2020, interacted with occupation characteristics. Column (3) adds occupation and industries fixed effects. All models include state fixed effects. Standard errors from multi-way clustering at the state and occupation level in parentheses. Statistical significance level: $* \mathrm{p}<0.1 ; * * \mathrm{p}<0.05 ; * * * \mathrm{p}<0.01$ 
Table A10.2: Cross-Sectional Models: Using data for 2019 - Temporary Absent

\begin{tabular}{|c|c|c|c|c|c|c|}
\hline \multicolumn{7}{|c|}{ Dependent $=$ Employed - Absent from Work } \\
\hline & \multicolumn{3}{|c|}{ April - Mean $=0.0242$} & \multicolumn{3}{|c|}{ May - Mean $=0.0248$} \\
\hline & (1) & (2) & (3) & (1) & (2) & (3) \\
\hline Face-to-Face & $\begin{array}{c}0.003^{* * *} \\
(0.001)\end{array}$ & $\begin{array}{c}-0.004 \\
(0.005)\end{array}$ & & $\begin{array}{c}0.002^{* *} \\
(0.001)\end{array}$ & $\begin{array}{l}0.007^{*} \\
(0.004)\end{array}$ & \\
\hline Remote Work & $\begin{array}{l}-0.001 \\
(0.001)\end{array}$ & $\begin{array}{c}-0.006 \\
(0.004)\end{array}$ & & $\begin{array}{l}-0.001 \\
(0.001)\end{array}$ & $\begin{array}{c}0.008 \\
(0.007)\end{array}$ & \\
\hline Essential & $\begin{array}{l}-0.002 \\
(0.003)\end{array}$ & $\begin{array}{c}0.006 \\
(0.012)\end{array}$ & & $\begin{array}{c}0.002 \\
(0.003)\end{array}$ & $\begin{array}{c}0.007 \\
(0.015)\end{array}$ & \\
\hline Ln(COVID cases) $x$ Face-to-Face & & $\begin{array}{c}0.001 \\
(0.001)\end{array}$ & $\begin{array}{l}0.001^{*} \\
(0.000)\end{array}$ & & $\begin{array}{l}-0.000 \\
(0.000)\end{array}$ & $\begin{array}{l}-0.000 \\
(0.000)\end{array}$ \\
\hline Ln(COVID cases $) \times$ Remote & & $\begin{array}{c}0.001 \\
(0.000)\end{array}$ & $\begin{array}{c}0.001 \\
(0.000)\end{array}$ & & $\begin{array}{l}-0.001 \\
(0.001)\end{array}$ & $\begin{array}{l}-0.001 \\
(0.001)\end{array}$ \\
\hline Ln(COVID cases) $x$ Essential & & $\begin{array}{l}-0.001 \\
(0.001)\end{array}$ & $\begin{array}{l}-0.001 \\
(0.001)\end{array}$ & & $\begin{array}{l}-0.000 \\
(0.002)\end{array}$ & $\begin{array}{l}-0.001 \\
(0.002)\end{array}$ \\
\hline Fem x Child-U6 & $\begin{array}{c}0.024^{* * *} \\
(0.006)\end{array}$ & $\begin{array}{c}0.024^{* * *} \\
(0.006)\end{array}$ & $\begin{array}{c}0.024^{* * *} \\
(0.006)\end{array}$ & $\begin{array}{c}0.026^{* * *} \\
(0.007)\end{array}$ & $\begin{array}{c}0.026^{* * *} \\
(0.007)\end{array}$ & $\begin{array}{c}0.025^{* * *} \\
(0.006)\end{array}$ \\
\hline Child under 6 & $\begin{array}{c}0.004 \\
(0.004)\end{array}$ & $\begin{array}{c}0.003 \\
(0.004)\end{array}$ & $\begin{array}{c}0.003 \\
(0.004)\end{array}$ & $\begin{array}{c}0.005 \\
(0.003)\end{array}$ & $\begin{array}{c}0.005 \\
(0.003)\end{array}$ & $\begin{array}{c}0.004 \\
(0.003)\end{array}$ \\
\hline Female & $\begin{array}{c}0.004^{* * *} \\
(0.001)\end{array}$ & $\begin{array}{c}0.004^{* * *} \\
(0.001)\end{array}$ & $\begin{array}{c}0.006^{* * *} \\
(0.002)\end{array}$ & $\begin{array}{l}0.003^{*} \\
(0.002)\end{array}$ & $\begin{array}{l}0.003^{*} \\
(0.002)\end{array}$ & $\begin{array}{c}0.004^{* * *} \\
(0.002)\end{array}$ \\
\hline Black & $\begin{array}{l}-0.003 \\
(0.002)\end{array}$ & $\begin{array}{l}-0.003 \\
(0.002)\end{array}$ & $\begin{array}{l}-0.002 \\
(0.002)\end{array}$ & $\begin{array}{c}0.001 \\
(0.005)\end{array}$ & $\begin{array}{c}0.001 \\
(0.005)\end{array}$ & $\begin{array}{l}-0.001 \\
(0.005)\end{array}$ \\
\hline Hispanic & $\begin{array}{l}-0.003 \\
(0.003)\end{array}$ & $\begin{array}{c}-0.003 \\
(0.003)\end{array}$ & $\begin{array}{l}-0.003 \\
(0.003)\end{array}$ & $\begin{array}{l}-0.001 \\
(0.002)\end{array}$ & $\begin{array}{l}-0.001 \\
(0.002)\end{array}$ & $\begin{array}{l}-0.001 \\
(0.002)\end{array}$ \\
\hline Age & $\begin{array}{c}-0.091^{*} \\
(0.053)\end{array}$ & $\begin{array}{c}-0.090^{*} \\
(0.053)\end{array}$ & $\begin{array}{c}-0.098 \\
(0.059)\end{array}$ & $\begin{array}{c}-0.101^{* *} \\
(0.047)\end{array}$ & $\begin{array}{c}-0.102^{* *} \\
(0.048)\end{array}$ & $\begin{array}{c}-0.126^{* * *} \\
(0.045)\end{array}$ \\
\hline $\operatorname{Age}^{2}$ & $\begin{array}{c}0.144^{* *} \\
(0.066)\end{array}$ & $\begin{array}{c}0.144^{* *} \\
(0.066)\end{array}$ & $\begin{array}{c}0.154^{* *} \\
(0.073)\end{array}$ & $\begin{array}{c}0.156^{* * *} \\
(0.058)\end{array}$ & $\begin{array}{c}0.157^{* * *} \\
(0.058)\end{array}$ & $\begin{array}{c}0.178^{* * *} \\
(0.056)\end{array}$ \\
\hline HS & $\begin{array}{c}-0.007 \\
(0.004)\end{array}$ & $\begin{array}{l}-0.007 \\
(0.004)\end{array}$ & $\begin{array}{l}-0.007 \\
(0.004)\end{array}$ & $\begin{array}{l}-0.002 \\
(0.003)\end{array}$ & $\begin{array}{l}-0.002 \\
(0.003)\end{array}$ & $\begin{array}{l}-0.003 \\
(0.003)\end{array}$ \\
\hline Some College & $\begin{array}{l}-0.004 \\
(0.005)\end{array}$ & $\begin{array}{c}-0.004 \\
(0.005)\end{array}$ & $\begin{array}{l}-0.004 \\
(0.005)\end{array}$ & $\begin{array}{c}0.005 \\
(0.003)\end{array}$ & $\begin{array}{c}0.005 \\
(0.003)\end{array}$ & $\begin{array}{c}0.005 \\
(0.003)\end{array}$ \\
\hline BA Degree & $\begin{array}{l}-0.005 \\
(0.004)\end{array}$ & $\begin{array}{l}-0.005 \\
(0.004)\end{array}$ & $\begin{array}{l}-0.007 \\
(0.005)\end{array}$ & $\begin{array}{c}0.004 \\
(0.003)\end{array}$ & $\begin{array}{c}0.004 \\
(0.003)\end{array}$ & $\begin{array}{c}0.005 \\
(0.003)\end{array}$ \\
\hline Posgraduate Degree & $\begin{array}{l}-0.003 \\
(0.005)\end{array}$ & $\begin{array}{l}-0.003 \\
(0.005)\end{array}$ & $\begin{array}{c}-0.006 \\
(0.006)\end{array}$ & $\begin{array}{l}-0.000 \\
(0.004)\end{array}$ & $\begin{array}{c}-0.000 \\
(0.004)\end{array}$ & $\begin{array}{c}0.005 \\
(0.004)\end{array}$ \\
\hline Metropolitan & $\begin{array}{c}0.002 \\
(0.003)\end{array}$ & $\begin{array}{c}0.001 \\
(0.003)\end{array}$ & $\begin{array}{c}0.001 \\
(0.004)\end{array}$ & $\begin{array}{c}0.004 \\
(0.003)\end{array}$ & $\begin{array}{c}0.004 \\
(0.003)\end{array}$ & $\begin{array}{c}0.005 \\
(0.003)\end{array}$ \\
\hline Constant & $\begin{array}{c}0.036^{* * *} \\
(0.013)\end{array}$ & $\begin{array}{l}0.036^{* * *} \\
(0.013)\end{array}$ & $\begin{array}{c}0.043^{* *} \\
(0.016)\end{array}$ & $\begin{array}{l}0.027^{* * *} \\
(0.010)\end{array}$ & $\begin{array}{l}0.027^{* * *} \\
(0.010)\end{array}$ & $\begin{array}{c}0.036^{* * *} \\
(0.013)\end{array}$ \\
\hline $\begin{array}{l}\text { State f.e. } \\
\text { Occupation \& Industries f.e. }\end{array}$ & $X$ & $\mathrm{X}$ & $\begin{array}{l}X \\
X\end{array}$ & $\mathrm{X}$ & $\mathrm{X}$ & $\begin{array}{l}X \\
X\end{array}$ \\
\hline $\begin{array}{l}\text { Observations } \\
R^{2}\end{array}$ & $\begin{array}{c}40268 \\
0.008\end{array}$ & $\begin{array}{c}40268 \\
0.008\end{array}$ & $\begin{array}{c}40268 \\
0.030\end{array}$ & $\begin{array}{l}39630 \\
0.005\end{array}$ & $\begin{array}{c}39630 \\
0.006\end{array}$ & $\begin{array}{l}39630 \\
0.030\end{array}$ \\
\hline
\end{tabular}

Notes: Coefficients for Equation 1 using April (left panel) and May (right panel) 2019 CPS Data for individuals on the labor force and with temporary absent from work as the dependent variable. Column (1) includes sociodemographic and job tasks' characteristics. Column (2) adds the states' epidemiological conditions as measured by their COVID-19 log exposure during the exact same month in 2020, interacted with occupation characteristics. Column (3) adds occupation and industries fixed effects. All models include state fixed effects. Standard errors from multi-way clustering at the state and occupation level in parentheses. Statistical significance level: $* \mathrm{p}<0.1 ; * * \mathrm{p}<0.05$; $* * * \mathrm{p}<0.01$ 


\section{A.11 Sensitivity to Definition of "Recent" Unemployment in Weeks}

In this section we show results that test the sensibility of our estimates to the definition of the recent unemployment variable. As explained in sections 3 and A.1, we use a window of 5 weeks for March, 10 for April, and 14 weeks for May. Figures A11.1 and A11.2 show how the estimates of model in columns (3) of the regression tables would change as we vary the size of the window used for the definition of the "recent unemployed" variable. Overall, we observe that the estimates are pretty robust to such sensitivity check. 
Figure A11.1: Sensibility of Coefficients from Equation 1 to Weeks considered in Recent Unemployment - April

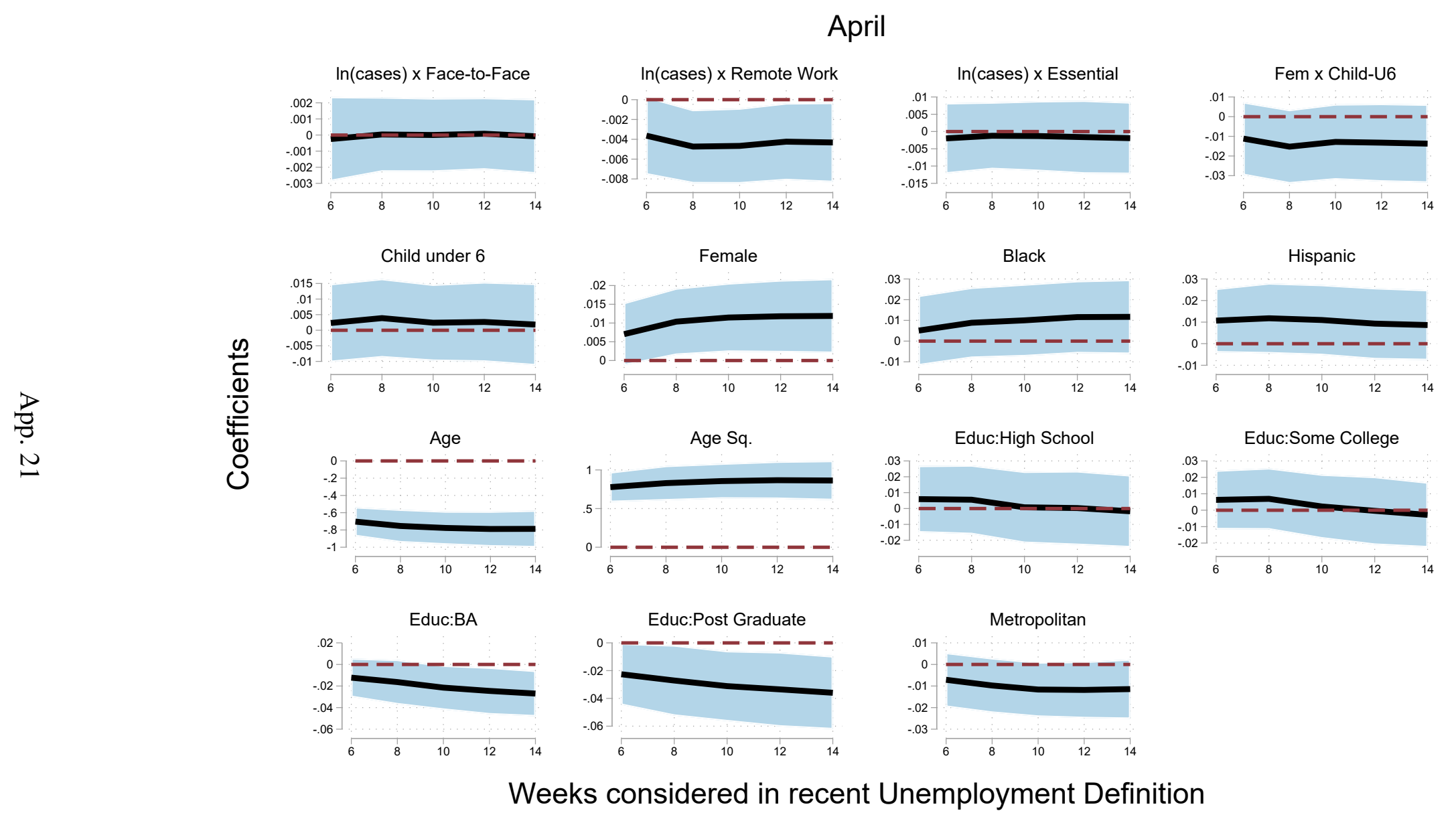

Note: Figures present the coefficients from Equation 1 using April 2020 CPS Data for individuals on the labor force and with different definitions of recent unemployment varying the definition of the number of weeks considered. In each panel, the x-axis is the range of week-windows that we test as part of the sensitivity analysis. The y-axis represents the coefficient, and its confidence interval. The model presents results for the specification that considers state, occupation and industry fixed effects, comparable to Column (3) in Table 1 
Figure A11.2: Sensibility of Coefficients from Equation 1 to Weeks considered in Recent Unemployment - May

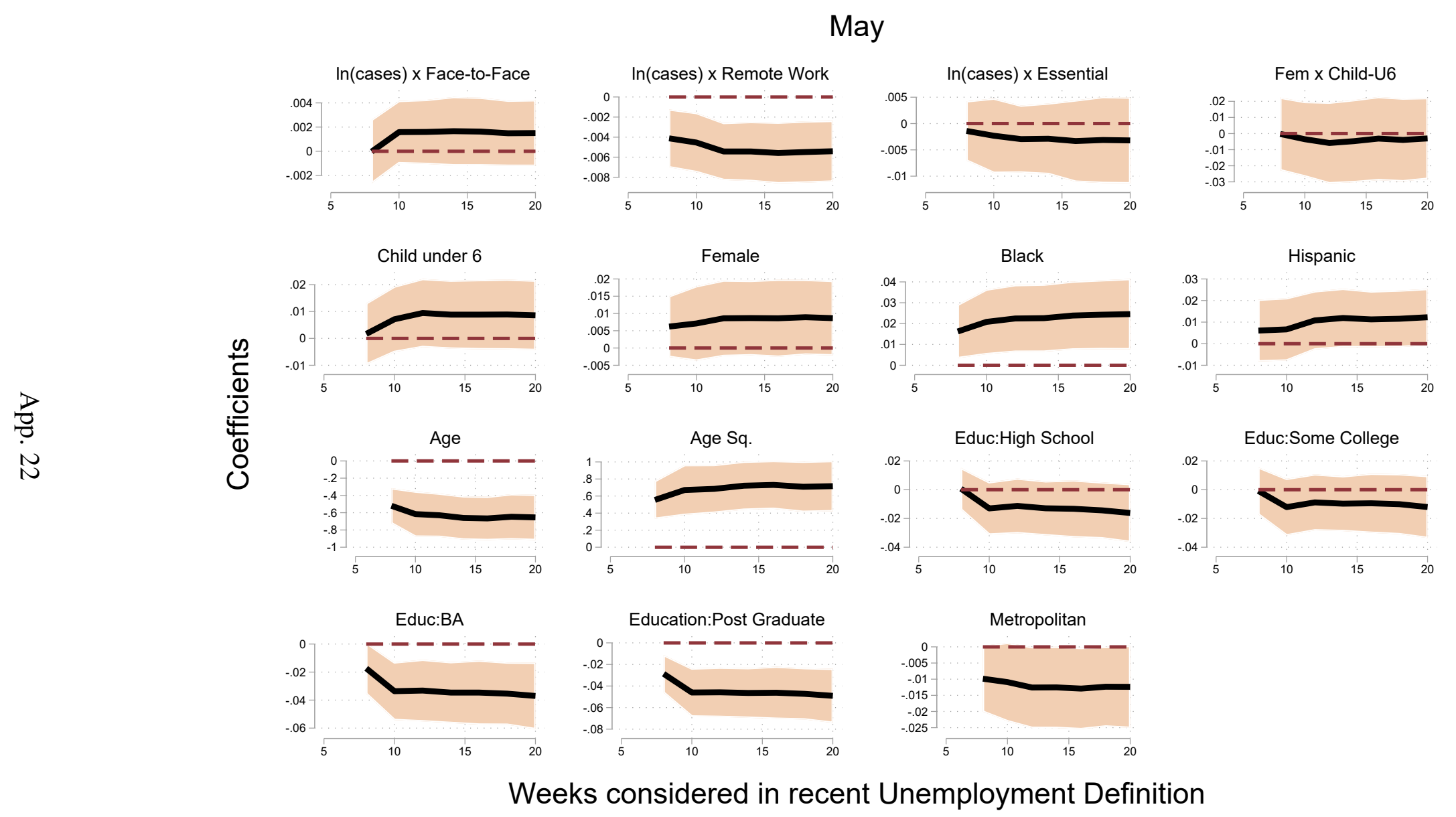

Note: Figures present the coefficients from Equation 1 using May 2020 CPS Data for individuals in the labor force and with different definitions of recent unemployment, varying the definition of the number of weeks considered. In each panel, the x-axis is the range of week-windows that we test as part of the sensitivity analysis. The y-axis represents the coefficient, and its confidence interval. The model presents results for the specification that considers state, occupation and industry fixed effects, comparable to Column (3) in Table 1. 


\section{A.12 Sensitivity to definitions of Face-to-Face and Remote Work}

In this section we show results that test the robustness of our results to substituting our Remote Work index with Teleworkable index in Dingel and Neiman (2020). Hence, we replace our Remote Work index with Teleworkable and reproduce the regression estimates reported in Table 1 and 2.

Table A12.1: Cross-Sectional Models: Using Teleworkable definition - Recent Unemployment

\begin{tabular}{|c|c|c|c|c|c|c|}
\hline \multicolumn{7}{|l|}{ Dependent $=$ Recently Unemployed } \\
\hline & \multicolumn{3}{|c|}{ April - Mean $=0.126$} & \multicolumn{3}{|c|}{ May - Mean $=0.112$} \\
\hline & (1) & (2) & (3) & (1) & (2) & (3) \\
\hline Face-to-Face & $\begin{array}{c}0.007 \\
(0.007)\end{array}$ & $\begin{array}{c}0.021 \\
(0.013)\end{array}$ & & $\begin{array}{c}0.009 \\
(0.006)\end{array}$ & $\begin{array}{c}0.000 \\
(0.017)\end{array}$ & \\
\hline Teleworkable & $\begin{array}{c}-0.073^{* * *} \\
(0.016)\end{array}$ & $\begin{array}{c}0.036 \\
(0.039)\end{array}$ & & $\begin{array}{c}-0.056^{* * *} \\
(0.013)\end{array}$ & $\begin{array}{c}0.065 \\
(0.040)\end{array}$ & \\
\hline Essential & $\begin{array}{c}-0.100^{* * *} \\
(0.013)\end{array}$ & $\begin{array}{c}-0.070^{*} \\
(0.037)\end{array}$ & & $\begin{array}{c}-0.082^{* * *} \\
(0.011)\end{array}$ & $\begin{array}{l}-0.045 \\
(0.030)\end{array}$ & \\
\hline $\operatorname{Ln}($ COVID cases) $x$ Face-to-Face & & $\begin{array}{l}-0.001 \\
(0.001)\end{array}$ & $\begin{array}{l}-0.001 \\
(0.001)\end{array}$ & & $\begin{array}{c}0.001 \\
(0.002)\end{array}$ & $\begin{array}{c}0.000 \\
(0.002)\end{array}$ \\
\hline Ln(COVID cases) $x$ Teleworkable & & $\begin{array}{c}-0.012^{* * *} \\
(0.004)\end{array}$ & $\begin{array}{c}-0.011^{* *} \\
(0.004)\end{array}$ & & $\begin{array}{c}-0.012^{* * *} \\
(0.004)\end{array}$ & $\begin{array}{c}-0.011^{* * *} \\
(0.004)\end{array}$ \\
\hline Ln(COVID cases) $x$ Essential & & $\begin{array}{l}-0.003 \\
(0.004)\end{array}$ & $\begin{array}{c}-0.003 \\
(0.004)\end{array}$ & & $\begin{array}{l}-0.004 \\
(0.003)\end{array}$ & $\begin{array}{c}-0.004 \\
(0.003)\end{array}$ \\
\hline Fem x Child-U6 & $\begin{array}{l}-0.006 \\
(0.011)\end{array}$ & $\begin{array}{l}-0.006 \\
(0.011)\end{array}$ & $\begin{array}{l}-0.013 \\
(0.009)\end{array}$ & $\begin{array}{c}0.000 \\
(0.015)\end{array}$ & $\begin{array}{c}0.000 \\
(0.015)\end{array}$ & $\begin{array}{l}-0.005 \\
(0.013)\end{array}$ \\
\hline Child under 6 & $\begin{array}{l}-0.010 \\
(0.007)\end{array}$ & $\begin{array}{l}-0.010 \\
(0.007)\end{array}$ & $\begin{array}{c}0.002 \\
(0.006)\end{array}$ & $\begin{array}{c}-0.001 \\
(0.008)\end{array}$ & $\begin{array}{l}-0.001 \\
(0.008)\end{array}$ & $\begin{array}{c}0.009 \\
(0.006)\end{array}$ \\
\hline Female & $\begin{array}{c}0.031^{* * *} \\
(0.009)\end{array}$ & $\begin{array}{c}0.031^{* * *} \\
(0.009)\end{array}$ & $\begin{array}{c}0.011^{* *} \\
(0.004)\end{array}$ & $\begin{array}{c}0.026^{* * *} \\
(0.008)\end{array}$ & $\begin{array}{c}0.026^{* * *} \\
(0.008)\end{array}$ & $\begin{array}{c}0.009 \\
(0.005)\end{array}$ \\
\hline Black & $\begin{array}{c}0.006 \\
(0.009)\end{array}$ & $\begin{array}{c}0.006 \\
(0.009)\end{array}$ & $\begin{array}{c}0.010 \\
(0.009)\end{array}$ & $\begin{array}{c}0.023^{* *} \\
(0.009)\end{array}$ & $\begin{array}{c}0.023^{* *} \\
(0.009)\end{array}$ & $\begin{array}{c}0.023^{* * *} \\
(0.008)\end{array}$ \\
\hline Hispanic & $\begin{array}{c}0.018^{* *} \\
(0.008)\end{array}$ & $\begin{array}{c}0.018^{* *} \\
(0.008)\end{array}$ & $\begin{array}{c}0.011 \\
(0.008)\end{array}$ & $\begin{array}{c}0.020^{* *} \\
(0.008)\end{array}$ & $\begin{array}{c}0.020^{* *} \\
(0.008)\end{array}$ & $\begin{array}{l}0.012^{*} \\
(0.007)\end{array}$ \\
\hline Age & $\begin{array}{c}-1.334^{* * *} \\
(0.167)\end{array}$ & $\begin{array}{c}-1.340^{* * *} \\
(0.167)\end{array}$ & $\begin{array}{c}-0.775^{* * *} \\
(0.096)\end{array}$ & $\begin{array}{c}-1.230^{* * *} \\
(0.185)\end{array}$ & $\begin{array}{c}-1.235^{* * *} \\
(0.184)\end{array}$ & $\begin{array}{c}-0.658^{* * *} \\
(0.125)\end{array}$ \\
\hline $\mathrm{Age}^{2}$ & $\begin{array}{c}1.422^{* * *} \\
(0.179)\end{array}$ & $\begin{array}{c}1.428^{* * *} \\
(0.178)\end{array}$ & $\begin{array}{c}0.855^{* * *} \\
(0.113)\end{array}$ & $\begin{array}{c}1.303^{* * *} \\
(0.205)\end{array}$ & $\begin{array}{c}1.308^{* * *} \\
(0.204)\end{array}$ & $\begin{array}{c}0.719^{* * *} \\
(0.140)\end{array}$ \\
\hline HS & $\begin{array}{l}-0.020 \\
(0.013)\end{array}$ & $\begin{array}{l}-0.020 \\
(0.013)\end{array}$ & $\begin{array}{c}0.001 \\
(0.011)\end{array}$ & $\begin{array}{c}-0.022^{*} \\
(0.012)\end{array}$ & $\begin{array}{c}-0.021^{*} \\
(0.012)\end{array}$ & $\begin{array}{l}-0.013 \\
(0.009)\end{array}$ \\
\hline Some College & $\begin{array}{c}-0.029^{* *} \\
(0.013)\end{array}$ & $\begin{array}{c}-0.029^{* *} \\
(0.013)\end{array}$ & $\begin{array}{c}0.002 \\
(0.010)\end{array}$ & $\begin{array}{c}-0.028^{* *} \\
(0.012)\end{array}$ & $\begin{array}{c}-0.028^{* *} \\
(0.012)\end{array}$ & $\begin{array}{l}-0.010 \\
(0.009)\end{array}$ \\
\hline BA Degree & $\begin{array}{c}-0.082^{* * *} \\
(0.015)\end{array}$ & $\begin{array}{c}-0.082^{* * *} \\
(0.015)\end{array}$ & $\begin{array}{c}-0.021^{* *} \\
(0.010)\end{array}$ & $\begin{array}{c}-0.076^{* * *} \\
(0.015)\end{array}$ & $\begin{array}{c}-0.076^{* * *} \\
(0.015)\end{array}$ & $\begin{array}{c}-0.035^{* * *} \\
(0.011)\end{array}$ \\
\hline Posgraduate Degree & $\begin{array}{c}-0.117^{* * *} \\
(0.015)\end{array}$ & $\begin{array}{c}-0.117^{* * *} \\
(0.015)\end{array}$ & $\begin{array}{c}-0.031^{* *} \\
(0.013)\end{array}$ & $\begin{array}{c}-0.110^{* * *} \\
(0.015)\end{array}$ & $\begin{array}{c}-0.109^{* * *} \\
(0.015)\end{array}$ & $\begin{array}{c}-0.047^{* * *} \\
(0.011)\end{array}$ \\
\hline Metropolitan & $\begin{array}{c}-0.026^{* * *} \\
(0.008)\end{array}$ & $\begin{array}{c}-0.025^{* * *} \\
(0.008)\end{array}$ & $\begin{array}{c}-0.012^{*} \\
(0.006)\end{array}$ & $\begin{array}{c}-0.026^{* * *} \\
(0.007)\end{array}$ & $\begin{array}{c}-0.025^{* * *} \\
(0.007)\end{array}$ & $\begin{array}{c}-0.013^{* *} \\
(0.006)\end{array}$ \\
\hline Constant & $\begin{array}{c}0.576^{* * *} \\
(0.043)\end{array}$ & $\begin{array}{c}0.577^{* * *} \\
(0.043)\end{array}$ & $\begin{array}{c}0.364^{* * *} \\
(0.039)\end{array}$ & $\begin{array}{c}0.515^{* * *} \\
(0.046)\end{array}$ & $\begin{array}{c}0.516^{* * *} \\
(0.046)\end{array}$ & $\begin{array}{c}0.352^{* * *} \\
(0.036)\end{array}$ \\
\hline $\begin{array}{l}\text { State f.e. } \\
\text { Occupation \& Industries f.e. }\end{array}$ & $\mathrm{X}$ & $\mathrm{X}$ & $\begin{array}{l}X \\
X\end{array}$ & $\mathrm{X}$ & $\mathrm{X}$ & $\begin{array}{l}X \\
X\end{array}$ \\
\hline $\begin{array}{l}\text { Observations } \\
R^{2}\end{array}$ & $\begin{array}{l}43754 \\
0.066\end{array}$ & $\begin{array}{l}43754 \\
0.067\end{array}$ & $\begin{array}{l}43754 \\
0.196\end{array}$ & $\begin{array}{c}42432 \\
0.058\end{array}$ & $\begin{array}{c}42432 \\
0.059\end{array}$ & $\begin{array}{c}42432 \\
0.172\end{array}$ \\
\hline
\end{tabular}

Notes: Coefficients for Equation 1 using April (left panel) and May (right panel) 2020 CPS Data for individuals on the labor force and with recent unemployment as the dependent variable. Column (1) includes socio-demographic and job tasks' characteristics. Column (2) adds the states' epidemiological conditions as measured by their COVID-19 log exposure, interacted with occupation characteristics. Column (3) adds occupation and industries fixed effects. All models include state fixed effects. Standard errors from multi-way clustering at the state and occupation level in parentheses. Statistical significance level: ${ }^{*} \mathrm{p}<0.1 ; * * \mathrm{p}<0.05 ; * * * \mathrm{p}<0.01$ 
Table A12.2: Cross-Sectional Models: Using Teleworkable definition - Temporary Absent

\begin{tabular}{|c|c|c|c|c|c|c|}
\hline \multicolumn{7}{|c|}{ Dependent $=$ Employed - Absent from Work } \\
\hline & \multicolumn{3}{|c|}{ April - Mean $=0.071$} & \multicolumn{3}{|c|}{ May - Mean $=0.050$} \\
\hline & (1) & (2) & (3) & (1) & (2) & (3) \\
\hline Face-to-Face & $\begin{array}{c}0.010^{* * *} \\
(0.004)\end{array}$ & $\begin{array}{c}0.006 \\
(0.014)\end{array}$ & & $\begin{array}{c}0.006^{* *} \\
(0.003)\end{array}$ & $\begin{array}{c}0.006 \\
(0.008)\end{array}$ & \\
\hline Teleworkable & $\begin{array}{c}-0.029^{* * *} \\
(0.007)\end{array}$ & $\begin{array}{c}0.036 \\
(0.023)\end{array}$ & & $\begin{array}{c}-0.022^{* * *} \\
(0.006)\end{array}$ & $\begin{array}{l}0.039^{*} \\
(0.021)\end{array}$ & \\
\hline Essential & $\begin{array}{c}-0.038^{* * *} \\
(0.007)\end{array}$ & $\begin{array}{c}-0.028 \\
(0.024)\end{array}$ & & $\begin{array}{c}-0.023^{* * *} \\
(0.006)\end{array}$ & $\begin{array}{c}-0.046^{* * *} \\
(0.013)\end{array}$ & \\
\hline Ln(COVID cases) x Face-to-Face & & $\begin{array}{c}0.000 \\
(0.002)\end{array}$ & $\begin{array}{c}0.001 \\
(0.002)\end{array}$ & & $\begin{array}{l}-0.000 \\
(0.001)\end{array}$ & $\begin{array}{c}0.000 \\
(0.001)\end{array}$ \\
\hline Ln(COVID cases) $x$ Teleworkable & & $\begin{array}{c}-0.007^{* *} \\
(0.003)\end{array}$ & $\begin{array}{c}-0.005^{*} \\
(0.003)\end{array}$ & & $\begin{array}{c}-0.006^{* * *} \\
(0.002)\end{array}$ & $\begin{array}{c}-0.005^{* *} \\
(0.002)\end{array}$ \\
\hline Ln(COVID cases $) \times$ Essential & & $\begin{array}{l}-0.001 \\
(0.003)\end{array}$ & $\begin{array}{l}-0.002 \\
(0.003)\end{array}$ & & $\begin{array}{c}0.002 \\
(0.001)\end{array}$ & $\begin{array}{c}0.002 \\
(0.002)\end{array}$ \\
\hline Fem x Child-U6 & $\begin{array}{c}0.038^{* * *} \\
(0.008)\end{array}$ & $\begin{array}{c}0.038^{* * *} \\
(0.008)\end{array}$ & $\begin{array}{c}0.037^{* * *} \\
(0.008)\end{array}$ & $\begin{array}{c}0.035^{* * *} \\
(0.005)\end{array}$ & $\begin{array}{c}0.034^{* * *} \\
(0.005)\end{array}$ & $\begin{array}{c}0.034^{* * *} \\
(0.006)\end{array}$ \\
\hline Child under 6 & $\begin{array}{l}-0.000 \\
(0.006)\end{array}$ & $\begin{array}{l}-0.000 \\
(0.006)\end{array}$ & $\begin{array}{c}0.001 \\
(0.006)\end{array}$ & $\begin{array}{l}-0.002 \\
(0.003)\end{array}$ & $\begin{array}{l}-0.002 \\
(0.003)\end{array}$ & $\begin{array}{l}-0.000 \\
(0.003)\end{array}$ \\
\hline Female & $\begin{array}{c}0.009^{* *} \\
(0.004)\end{array}$ & $\begin{array}{l}0.009^{*} \\
(0.004)\end{array}$ & $\begin{array}{c}0.001 \\
(0.003)\end{array}$ & $\begin{array}{c}0.010^{* * *} \\
(0.003)\end{array}$ & $\begin{array}{c}0.010^{* * *} \\
(0.003)\end{array}$ & $\begin{array}{c}0.007^{* *} \\
(0.003)\end{array}$ \\
\hline Black & $\begin{array}{c}0.005 \\
(0.005)\end{array}$ & $\begin{array}{c}0.005 \\
(0.006)\end{array}$ & $\begin{array}{c}0.006 \\
(0.005)\end{array}$ & $\begin{array}{c}0.005 \\
(0.005)\end{array}$ & $\begin{array}{c}0.005 \\
(0.005)\end{array}$ & $\begin{array}{c}0.006 \\
(0.005)\end{array}$ \\
\hline Hispanic & $\begin{array}{c}-0.006 \\
(0.010)\end{array}$ & $\begin{array}{c}-0.006 \\
(0.010)\end{array}$ & $\begin{array}{l}-0.008 \\
(0.009)\end{array}$ & $\begin{array}{l}-0.003 \\
(0.005)\end{array}$ & $\begin{array}{l}-0.003 \\
(0.005)\end{array}$ & $\begin{array}{l}-0.003 \\
(0.004)\end{array}$ \\
\hline Age & $\begin{array}{l}-0.006 \\
(0.089)\end{array}$ & $\begin{array}{l}-0.010 \\
(0.089)\end{array}$ & $\begin{array}{c}0.041 \\
(0.079)\end{array}$ & $\begin{array}{l}-0.041 \\
(0.072)\end{array}$ & $\begin{array}{l}-0.044 \\
(0.072)\end{array}$ & $\begin{array}{l}-0.052 \\
(0.067)\end{array}$ \\
\hline $\operatorname{Age}^{2}$ & $\begin{array}{c}0.070 \\
(0.104)\end{array}$ & $\begin{array}{c}0.073 \\
(0.104)\end{array}$ & $\begin{array}{c}0.027 \\
(0.091)\end{array}$ & $\begin{array}{c}0.100 \\
(0.076)\end{array}$ & $\begin{array}{c}0.102 \\
(0.076)\end{array}$ & $\begin{array}{l}0.118^{*} \\
(0.070)\end{array}$ \\
\hline HS & $\begin{array}{c}0.002 \\
(0.008)\end{array}$ & $\begin{array}{c}0.002 \\
(0.008)\end{array}$ & $\begin{array}{c}0.009 \\
(0.009)\end{array}$ & $\begin{array}{l}-0.007 \\
(0.007)\end{array}$ & $\begin{array}{l}-0.007 \\
(0.007)\end{array}$ & $\begin{array}{l}-0.004 \\
(0.008)\end{array}$ \\
\hline Some College & $\begin{array}{l}-0.011 \\
(0.008)\end{array}$ & $\begin{array}{l}-0.011 \\
(0.008)\end{array}$ & $\begin{array}{c}0.001 \\
(0.010)\end{array}$ & $\begin{array}{c}0.000 \\
(0.008)\end{array}$ & $\begin{array}{c}0.001 \\
(0.008)\end{array}$ & $\begin{array}{c}0.004 \\
(0.008)\end{array}$ \\
\hline BA Degree & $\begin{array}{c}-0.035^{* * *} \\
(0.008)\end{array}$ & $\begin{array}{c}-0.035^{* * *} \\
(0.008)\end{array}$ & $\begin{array}{l}-0.015 \\
(0.011)\end{array}$ & $\begin{array}{c}-0.017^{* *} \\
(0.007)\end{array}$ & $\begin{array}{c}-0.017^{* *} \\
(0.007)\end{array}$ & $\begin{array}{l}-0.008 \\
(0.007)\end{array}$ \\
\hline Posgraduate Degree & $\begin{array}{c}-0.054^{* * *} \\
(0.011)\end{array}$ & $\begin{array}{c}-0.054^{* * *} \\
(0.010)\end{array}$ & $\begin{array}{c}-0.026^{* *} \\
(0.012)\end{array}$ & $\begin{array}{c}-0.032^{* * *} \\
(0.007)\end{array}$ & $\begin{array}{c}-0.032^{* * *} \\
(0.007)\end{array}$ & $\begin{array}{c}-0.015^{* *} \\
(0.006)\end{array}$ \\
\hline Metropolitan & $\begin{array}{l}-0.008 \\
(0.008)\end{array}$ & $\begin{array}{l}-0.008 \\
(0.008)\end{array}$ & $\begin{array}{l}-0.003 \\
(0.008)\end{array}$ & $\begin{array}{l}-0.003 \\
(0.005)\end{array}$ & $\begin{array}{l}-0.002 \\
(0.005)\end{array}$ & $\begin{array}{c}0.002 \\
(0.005)\end{array}$ \\
\hline Constant & $\begin{array}{c}0.122^{* * *} \\
(0.019)\end{array}$ & $\begin{array}{c}0.123^{* * *} \\
(0.019)\end{array}$ & $\begin{array}{c}0.085^{* * *} \\
(0.031)\end{array}$ & $\begin{array}{c}0.081^{* * *} \\
(0.015)\end{array}$ & $\begin{array}{c}0.081^{* * *} \\
(0.015)\end{array}$ & $\begin{array}{c}0.052^{* * *} \\
(0.018)\end{array}$ \\
\hline $\begin{array}{l}\text { State f.e. } \\
\text { Occupation \& Industries f.e. }\end{array}$ & $\mathrm{X}$ & $\mathrm{X}$ & $\begin{array}{l}X \\
X\end{array}$ & $\mathrm{X}$ & $\mathrm{X}$ & $\begin{array}{l}X \\
X\end{array}$ \\
\hline $\begin{array}{l}\text { Observations } \\
R^{2}\end{array}$ & $\begin{array}{c}43754 \\
0.023\end{array}$ & $\begin{array}{c}43754 \\
0.023\end{array}$ & $\begin{array}{c}43754 \\
0.074\end{array}$ & $\begin{array}{l}42432 \\
0.016\end{array}$ & $\begin{array}{r}42432 \\
0.016\end{array}$ & $\begin{array}{c}42432 \\
0.062\end{array}$ \\
\hline
\end{tabular}

Notes: Coefficients for Equation 1 using April (left panel) and May (right panel) 2020 CPS Data for individuals on the labor force and with temporary absent from work as the dependent variable. Column (1) includes socio-demographic and job tasks' characteristics. Column (2) adds the states' epidemiological conditions as measured by their COVID$19 \log$ exposure, interacted with occupation characteristics. Column (3) adds occupation and industries fixed effects. All models include state fixed effects. Standard errors from multi-way clustering at the state and occupation level in parentheses. Statistical significance level: $* \mathrm{p}<0.1$; $* * \mathrm{p}<0.05 ; * * * \mathrm{p}<0.01$ 


\section{A.13 Oaxaca-Blinder Decomposition: Additional Exercises}

This section shows full results of Oaxaca-Blinder decompositions discussed in Section 6. Tables A13.1 and A13.3 show the full decomposition results for Model A, B, and C, respectively, in the corresponding panel. Tables A13.2 and A13.4 report the share of variation explained by sorting across five top-level categories in the Census occupational classification system for Model B and C: "Management, Business, Science, and Arts", "Service", "Sales and Office", "Natural Resources, Construction, and Maintenance", "Production, Transportation, and Material Moving". We also show the exercises of replacing our Remote Work index with Teleworkable (Dingel and Neiman 2020) for Model A (both April 2020 and May 2020 sample) in Table A13.5. Finally, Table A13.6 and A13.7 replicate using 2019 CPS data, showing the pre-epidemic decomposition results. 
Table A13.1: Oaxaca-Blinder Decomposition for April

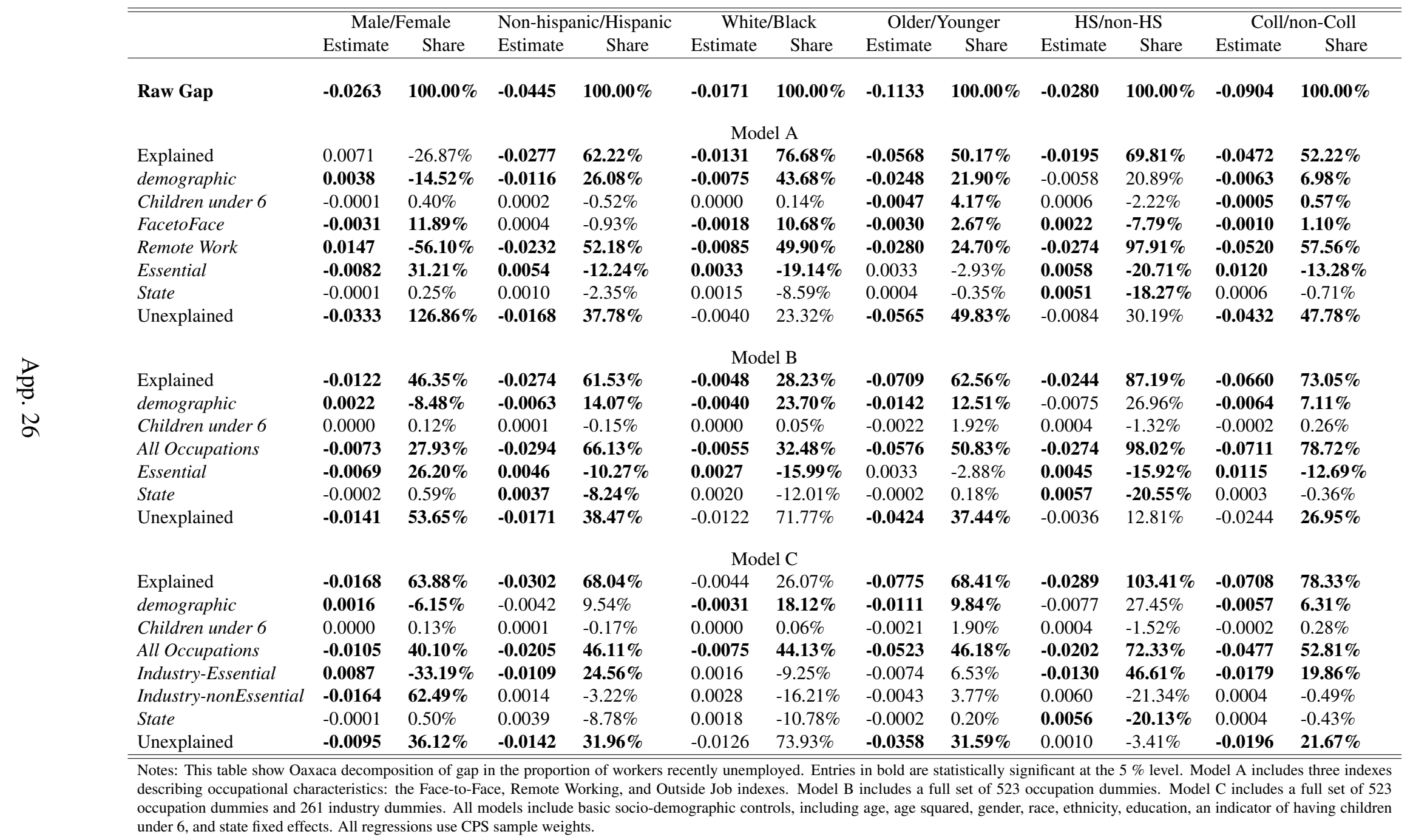


Table A13.2: Oaxaca-Blinder Decomposition for April: Five Occupation Groups

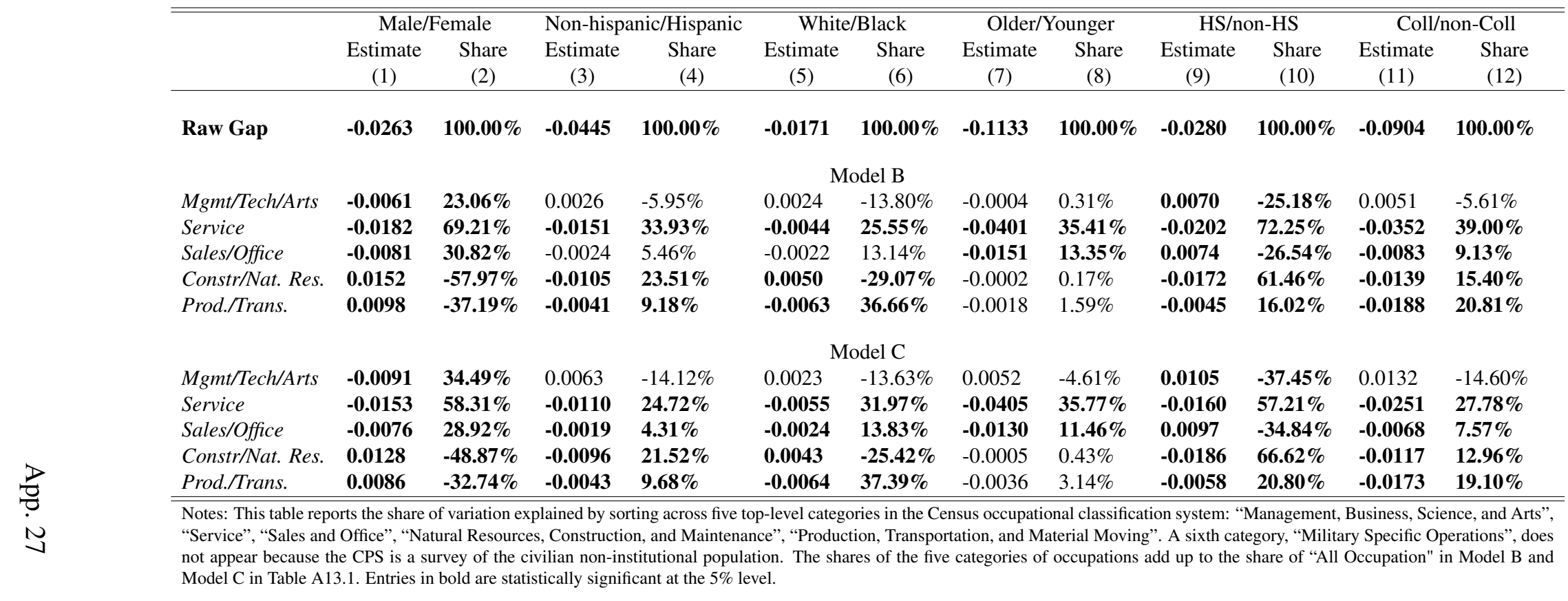


Table A13.3: Oaxaca-Blinder Decomposition for May

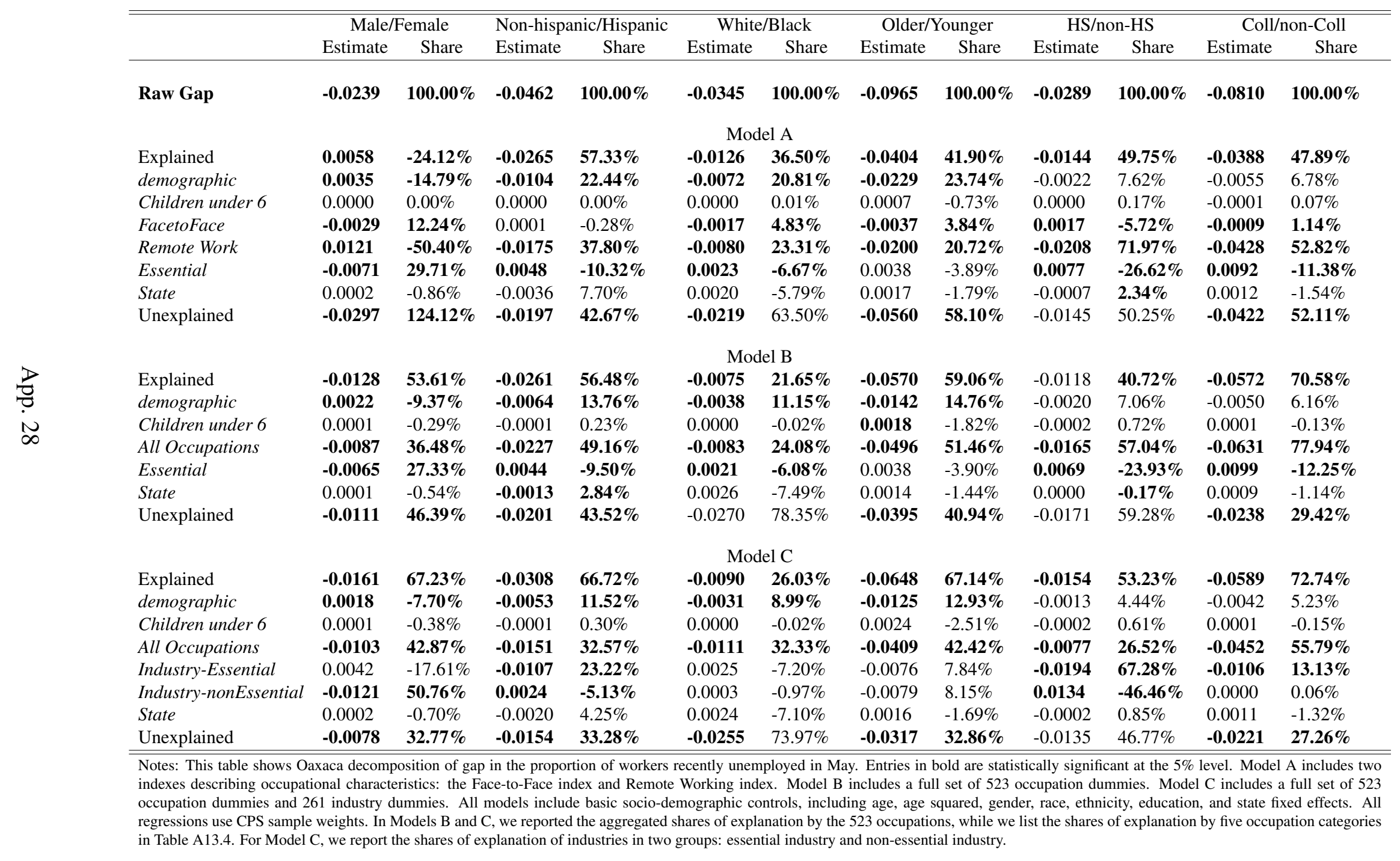


Table A13.4: Oaxaca-Blinder Decomposition for May: Five Occupation Groups

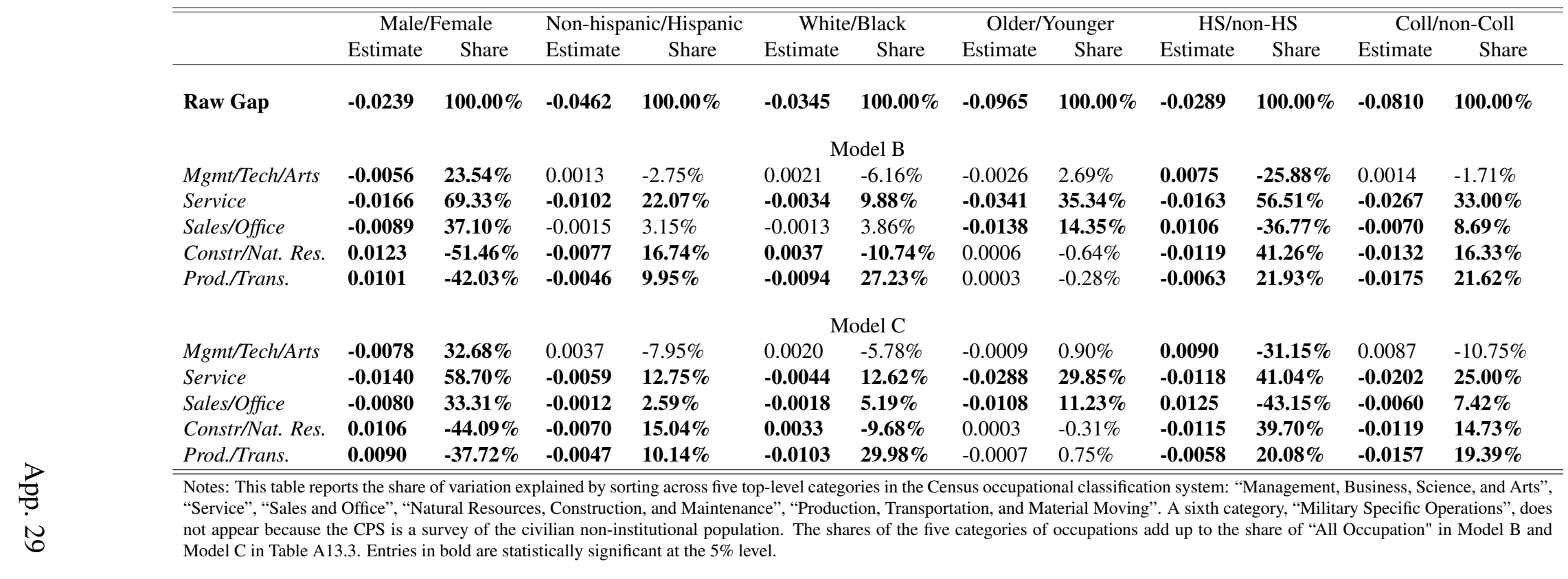


Table A13.5: Replicating Oaxaca-Blinder Decomposition Model A using "teleworkable"

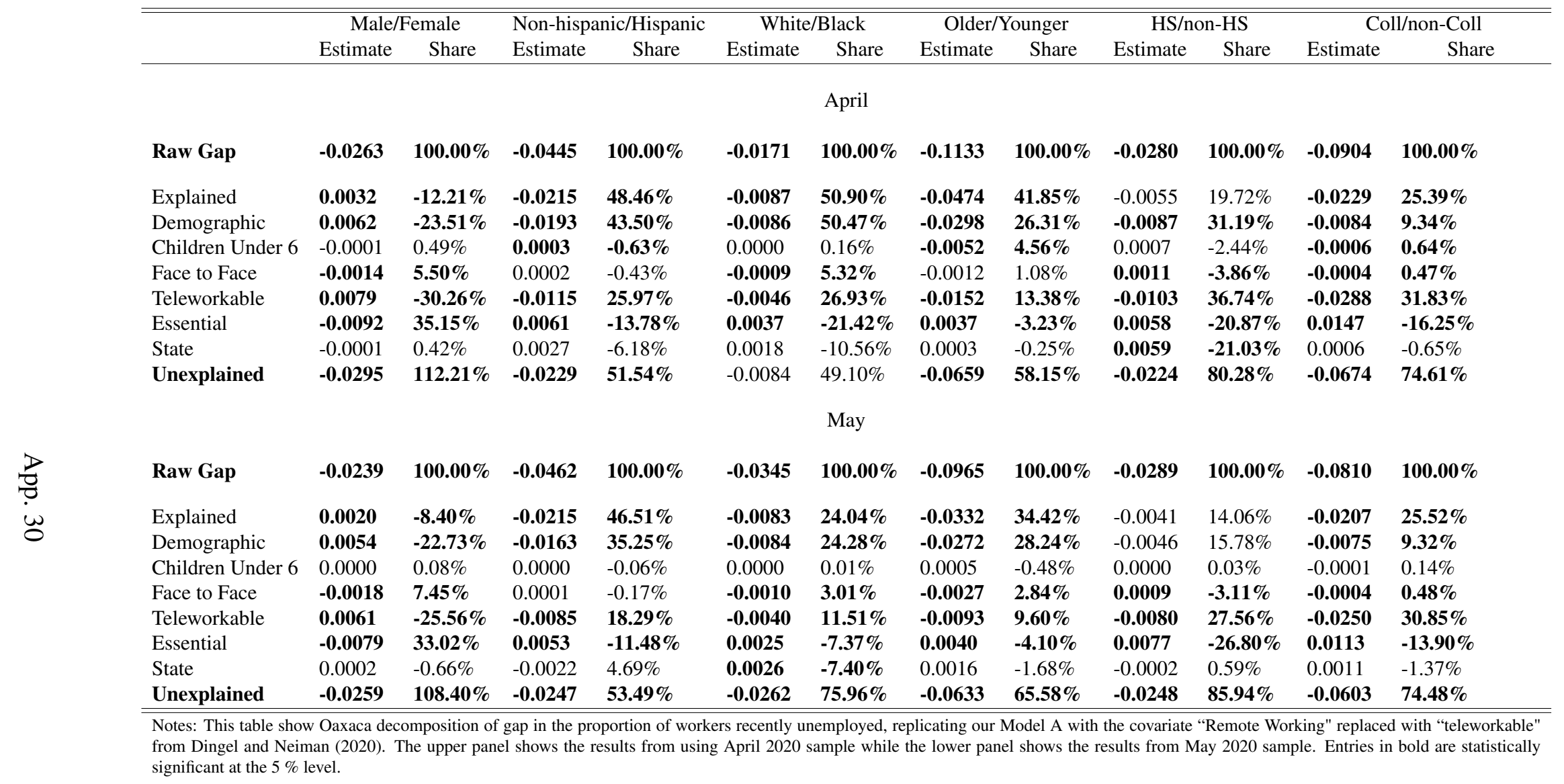


Table A13.6: Replicating Oaxaca-Blinder Decomposition, April 2019

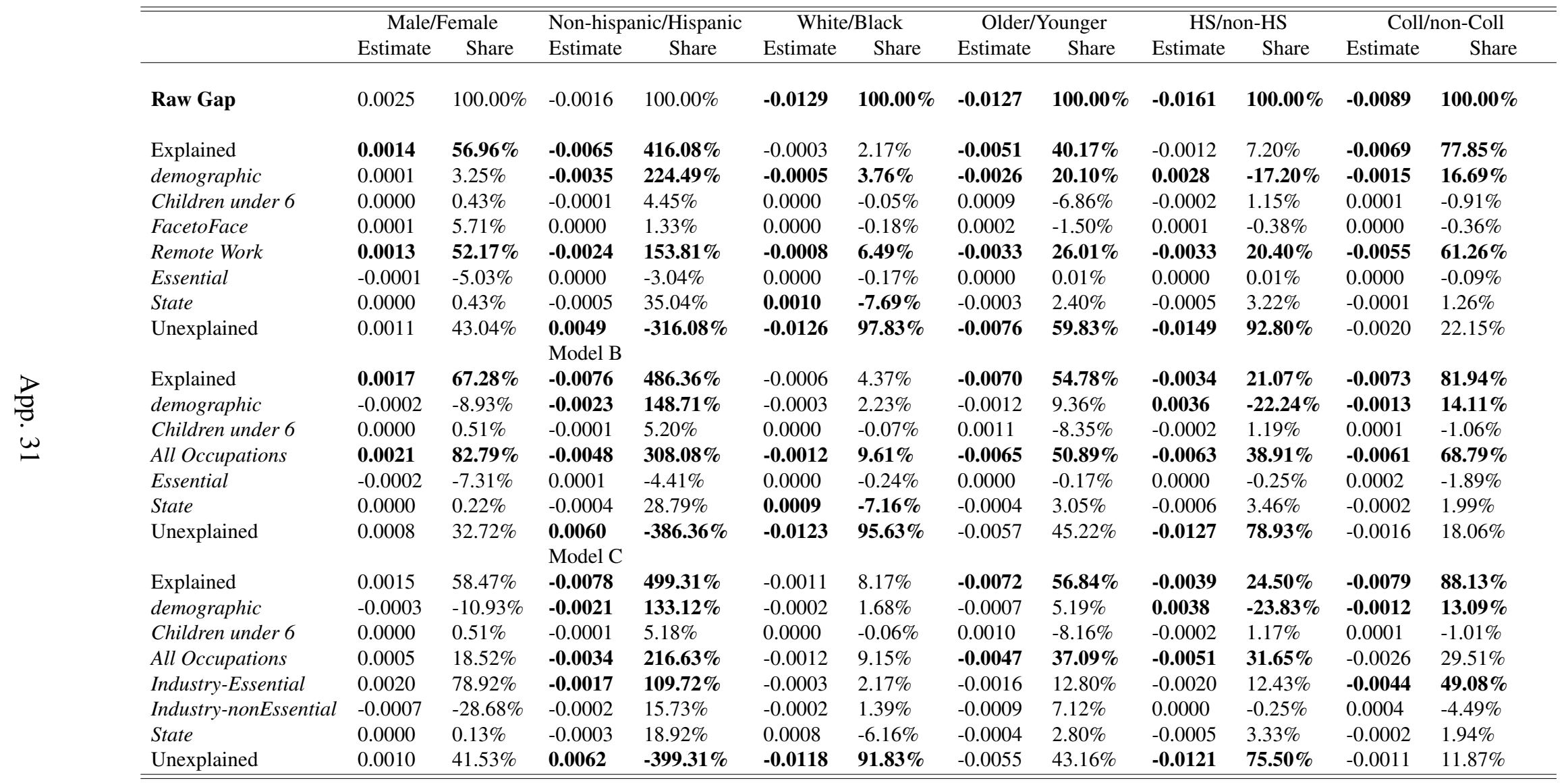

Notes: This table shows Oaxaca decomposition of gap in the proportion of workers recently unemployed in April, 2019. Entries in bold are statistically significant at the $5 \%$ level. Model A includes
two indexes describing occupational characteristics: the Face-to-Face index and Remote Working index. Model B includes a full set of 523 occupation dummies. Model C includes a full set of two indexes describing occupational characteristics: the Face-to-Face index and Remote Working index. Model B includes a full set of 523 occupation dummies. Model C includes a full set of
523 occupation dummies and 261 industry dummies. All models include basic socio-demographic controls, including age, age squared, gender, race, ethnicity, education, and state fixed effects. All regressions use CPS sample weights. In Models B and C, we reported the aggregated shares of explanation by the 523 occupations, while we list the shares of explanation by five occupation categories in Table A13.4. For Model C, we report the shares of explanation of industries in two groups: essential industry and non-essential industry. 
Table A13.7: Replicating Oaxaca-Blinder Decomposition, May 2019

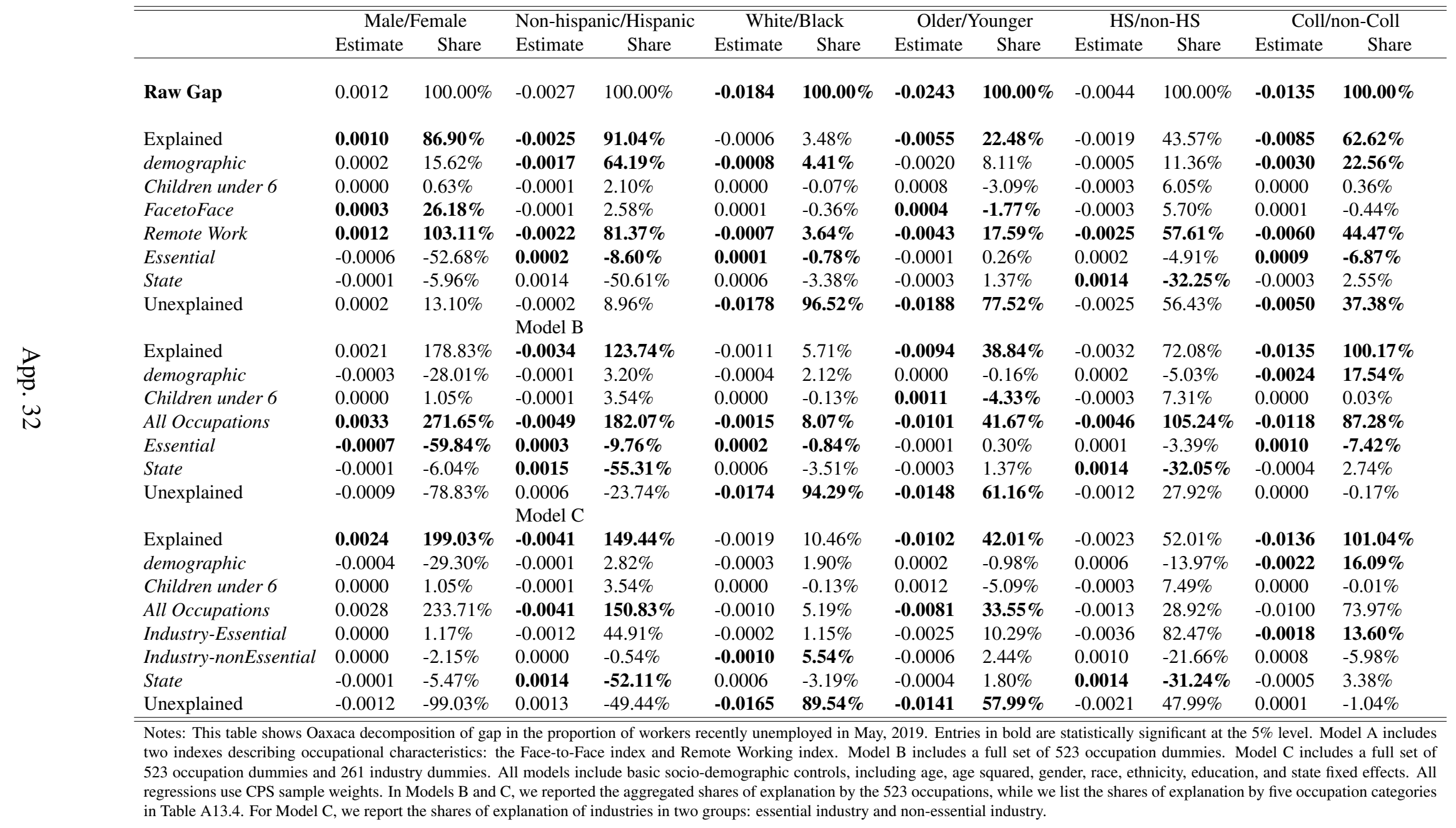

